\author{
UNIVERSIDADE DE SÃO PAULO \\ FACULDADE DE FILOSOFIA, LETRAS E CIÊNCIAS HUMANAS \\ DEPARTAMENTO DE FILOSOFIA \\ PROGRAMA DE PÓS-GRADUAÇÃO EM FILOSOFIA
}

Cynthia Sampaio de Gusmão

A harmônica na Antiguidade grega

São Paulo

2010 


\title{
A harmônica na Antiguidade grega
}

\author{
Dissertação apresentada ao \\ programa de Pós-Graduação em \\ Filosofia do Departamento de \\ Filosofia da Faculdade de Filosofia, \\ Letras e Ciências Humanas da \\ Universidade de São Paulo, para \\ obtenção do título de Mestre em \\ Filosofia sob a orientação do Prof. \\ Dr. Pablo Rubén Mariconda.
}

São Paulo

2010

\section{VERSÃO CORRIGIDA}

"De acordo"

Prof. Dr. Pablo Rubén Mariconda

São Paulo, 22 de março de 2011 
À minha bisavó Sophia Gaertner e sua filha Djanira, a muito amada Mami. 


\section{AGRADECIMENTOS}

Ao querido Professor Pablo Rubén Mariconda, por sua visão dinâmica e apaixonada do conhecimento, pelas sucessivas e poderosas intervenções e pela oportunidade.

À minha querida Silvana Issa Afram, pelas leituras cuidadosas, pela revisão do texto, pelo carinho e paciência.

À querida Professora Marília Pini, por ter aberto a minha visão em perspectiva.

Ao querido e saudoso Ricardo Rizek, por muitas coisas, dentre elas, por assumir o amor pela beleza da cosmologia pitagórica.

À querida Professora Annie Bélis, por me proporcionar o mergulho no contraponto aristoxeniano. 


\section{RESUMO}

Gusmão, Cynthia Sampaio de. A harmônica na Antiguidade grega. 2010. 101f. Dissertação de Mestrado, Faculdade de Filosofia, Letras e Ciências Humanas. Departamento de Filosofia, Universidade de São Paulo, São Paulo, 2010.

O presente trabalho apresenta as ideias centrais relacionadas às duas principais teorias acerca do som musical na Antiguidade grega, entre o final do século VI a.C. e o início do século III a.C. O estudo analisa, em primeiro lugar, as circunstâncias históricas e materiais que propiciaram o desenvolvimento da teoria musical grega, chamada harmônica, e a sua relação com a prática musical do período em questão. A primeira teoria analisada está inserida no contexto da escola pitagórica, em que a cosmologia é o referencial de uma visão de mundo que se expande conectando todas as áreas do pensamento, e um dos pontos de origem é a harmônica matemática. São apresentadas a seguir as demonstrações feitas a partir do cálculo das médias proporcionais e sua relação com o princípio da coesão harmônica da oitava. No segundo capítulo são estudadas as teorias acústicas da Antiguidade, que se originaram das razões pitagóricas e se desenvolveram no âmbito das ciências naturais, aprofundando-se com a filosofia aristotélica. No terceiro capítulo, são analisados os principais pontos de confronto promovidos pela corrente aristoxeniana, que se insere no quadro epistemológico aristotélico, e que foram levantados contra os pitagóricos. Nessa nova forma de

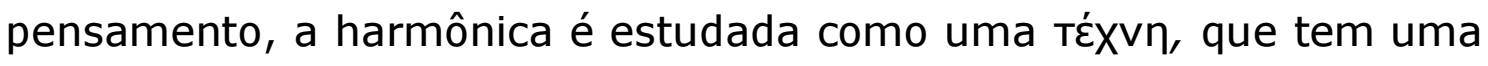

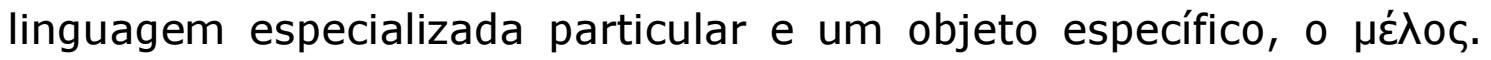
Ganha importância especial o conceito de ailoӨnoıৎ e, para colocá-lo

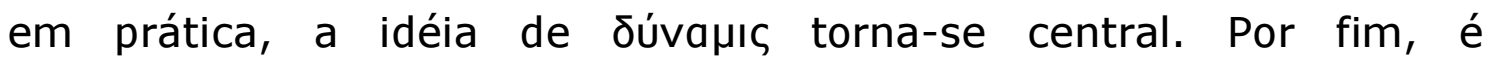
apresentada a persistência da concepção pitagórica nos cálculos dos intervalos musicais a partir da divisão do cânone.

Palavras-chaves: harmônica, pitagorismo, música, cosmologia,

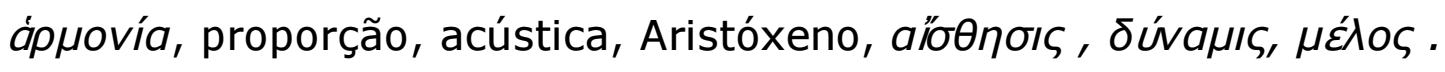




\section{ABSTRACT}

Gusmão, Cynthia Sampaio de. Harmonics in greek Antiquity. 2010. 101f. Thesis (Master Degree) - Faculdade de Filosofia, Letras e Ciências Humanas. Departamento de Filosofia, Universidade de São Paulo, São Paulo, 2010.

This work presents the central ideas related to two main theories about musical sound in greek Antiquity between the end of VI century and the beginning of III B.C. First, the historical and material contexts that lead to the development of greek musical theory, called Harmonics, are investigated, and its relationship with the musical practice of the period. The first theory analyzed comes from the pythagorean school, in which cosmology is the framework of a world view that expands connecting all areas of thought and one of its departure point is mathematical Harmonics. Afterwards, I discuss the demonstrations that are done from the calculations of proportional medias and their relations with the octave harmonic cohesion principle. In the second chapter, it's exposed the acoustic theories of Antiquity which originated from the musical ratios and had developed in the branch of natural sciences, deepening by the Aristotelian Philosophy. In the third chapter, I presented the most important issues concerning the differences between the aristoxenian current, which belongs to the aristotelian epistemological framework, against the pythagoreans. In this new way of thought, Harmonics is studied as a TÉXV $\eta$ that has a particular range of specialized terms and a

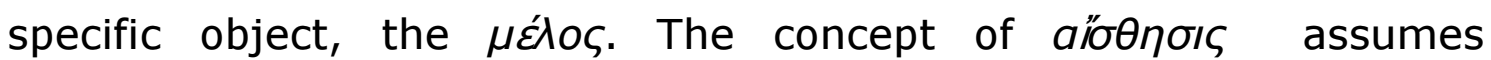

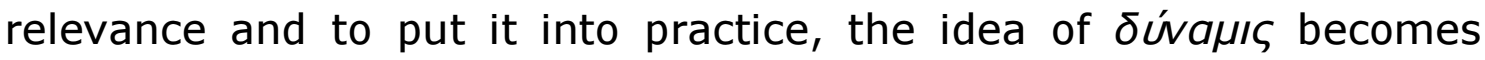
central. At last, the persistency of the pythagorean conception it is presented in the calculations of the musical intervals in the division of the canon.

Key-words: Harmonics, pythagorism, music, cosmology, ápuovía,

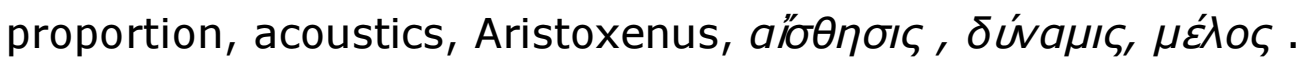




\section{SUMÁRIO}

Introdução

Capítulo I - Meios técnicos e estrutura da música grega

1. As origens musicais da harmônica

2. Os instrumentos musicais gregos

3. Aspectos da terminologia musical grega

4. As cordas e a estrutura musical grega

5. O epigóneon e a pandoûra

6. Afinação e gêneros musicais

Capítulo II - As origens matemáticas da harmônica

1. As disciplinas matemáticas

2. As razões numéricas musicais

3. A coesão harmônica da natureza

4. A fixação das consonâncias

5. A coma pitagórica

6. A cosmologia pitagórica

7. Os desdobramentos da harmônica: Arquitas

8. As médias proporcionais

9. A média geométrica e os incomensuráveis

2. Os primórdios da investigação do som

3. A propagação do som e sua audição

4. Os avanços da escola peripatética

5. As relações da acústica com a harmônica 


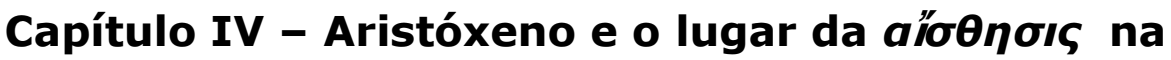
harmônica

1. Pequena nota biográfica 70

2. A proposta aristoxeniana 71

3. A organização do estudo 74

4. As partes da harmônica 76

5. Os intervalos aristoxenianos 80

6. A coesão do $\mu$ घ́lo५ 82

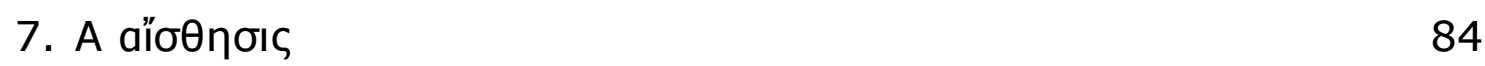

8. O diálogo com Aristóteles 86

9. Ressonâncias de Elementos de harmônica 88

Capítulo V - A Divisão do cânone 91

1. A longevidade da concepção pitagórica 91

2. A natureza do som 92

3. O rigor da canônica 94

4. Os corolários musicais 96

5. Dividindo o cânone 97

6. O apogeu da ciência pitagórica 98

Considerações finais 101

$\begin{array}{lr}\text { Bibliografia } & 109\end{array}$ 


\section{INTRODUÇÃO}

O tema do presente estudo são as abordagens teóricas que recebeu o som musical na Antiguidade grega entre o final do século VI a.C. e o início do século III a.C. A investigação ocorre no âmbito da Harmônica, um dos ramos da teoria musical grega, que, no entanto, difere do que se conhece por esse termo nos dias atuais. 0 musicólogo Carl Dahlhaus ${ }^{1}$ fez uma classificação tripartite dos grandes campos teóricos da música ocidental: o analítico, o regulativo e o especulativo. A via analítica estuda as obras musicais como modelos para a prática da composição e da apreciação crítica. A teoria regulativa abarca os escritos de instrução sobre as regras sintáticas da música, constituindo o assunto dos manuais dos musicógrafos que eclodiram a partir do século II d.C., e que foram os precursores daquilo que hoje é chamado de "teoria musical". O ramo especulativo é aquele que considera o aspecto ontológico da música, sua essência e matéria-prima. Esse último aspecto, sobre o qual se debruça a dissertação, teve presença marcante em mil anos de debates filosóficos e científicos da Antiguidade. Contudo, foi nos primeiros séculos que as questões cruciais foram colocadas, tendo o restante do milênio se dedicado a movimentar as mesmas peças no tabuleiro musical.

Os escritos musicais antigos, tanto gregos quanto latinos, em sua grande maioria, são especulativos e inserem-se no quadro geral de pensamento das escolas filosóficas; cada uma delas forja a teoria de acordo com seus métodos e princípios.

O filósofo Aristóxeno de Tarento, do século IV a.C, é um autêntico representante da escola peripatética, tendo sido aluno direto de Aristóteles. Sua obra Elementos de Harmônica é o mais

\footnotetext{
${ }^{1}$ Em Die Musiktheorie im 18. und 19. Jahrhundert: I, Grundzüge einer Systematik, Darmstadt, 1984, p.9-13. Apud Christensen, 2007, p.11.
} 
completo dos antigos tratados musicais gregos que chegaram até nós. No primeiro parágrafo, ele define o campo de investigação da

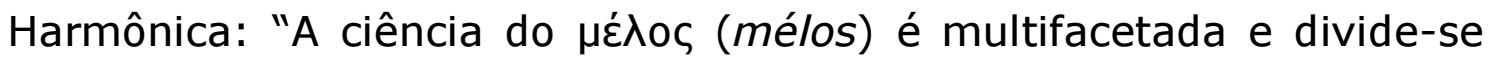
em muitos ramos; um deles é preciso tomar como base: o estudo da chamada Harmônica, primeira na ordem e com função elementar. De fato, sendo a primeira das matérias teóricas, ela abarca tudo que diz respeito ao estudo dos tons e das escalas. Sendo esta a finalidade do seu estudo, convém, pois, não considerá-la para além disso" (Meibom, 1, 11-25) ${ }^{2}$. Rosetta da Rios aponta em nota a sua tradução italiana do tratado: "Assim como, de fato, a qualidade dos sons é o elemento específico da música, pois o ritmo está presente na poesia e no canto, assim, no uso técnico de Aristóxeno e de seus seguidores, $\mu \varepsilon \dot{\lambda}$ oৎ passa a ser usado para significar exclusivamente a parte tonal da música ou a melodia no sentido comum, considerada como uma sucessão de notas de alturas diferentes, em contraposição ao ritmo. De fato, mais tarde quando se quiser designar melodia no sentido

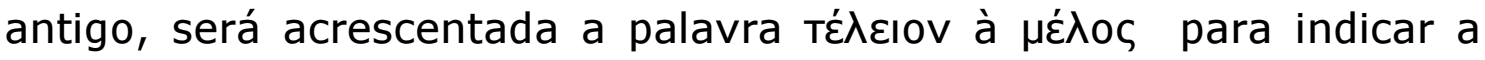
melodia acabada, com a presença do ritmo" (Rios, 1954, p.3, nota 2).

Portanto, Aristóxeno dá à palavra grega $\mu \varepsilon ́ \lambda o \varsigma$ um sentido especificamente tonal ${ }^{3}$, modificando a concepção anterior que a referia a uma combinação de palavra, ritmo e melodia. Ela é distinta desse $\mu \varepsilon \dot{\lambda} \lambda \varsigma_{\varsigma}$ composto ao qual poderíamos incluir elementos de coreografia, e que Platão e Aristóteles mencionaram ao atribuir efeitos da música ao comportamento humano, falando do ponto de vista do ñӨos musical. A música grega antiga, e especialmente a defendida por Platão, era eminentemente vocal - portanto, ligada a um texto poético - e também circunstancial, ou seja, destinada a ocasiões determinadas. Por isso, parece-nos desmedida a postura de

\footnotetext{
${ }^{2}$ Neste estudo utilizamos a mesma numeração que Rios como referência para a obra de Aristóxeno. Ela advém da compilação de Marcus Meibom, Antiquae Musicae Auctores, Amsterdam, 1652.

${ }^{3} \mathrm{O}$ termo tonal aqui não se refere ao sistema tonal que se desenvolveu muito mais tarde no Ocidente, mas apenas ao tom entendido como o som de altura definida.
} 
alguns autores modernos que defendem ter existido, na Grécia antiga, algo como uma ciência secreta do poder vibratório das estruturas melódicas em si mesmas. Winnington-Ingram, por exemplo, analisou a questão da seguinte forma: "Essa concepção de um caráter inerente dos modos não está restrita à Grécia; mas é visível aqui devido à fama de alguns autores e à interpretação moral que colocavam no caráter dos modos. (...) É mais pertinente expressar algum ceticismo, se os elementos musicais podem em si mesmos possuir tais caracteres tão marcados. Muitos outros fatores estão em jogo" (1968, p.3). De qualquer modo, é necessário atentar para que não haja justaposição de uma concepção de música eminentemente instrumental, que só se firmou totalmente a partir do século XVIII, ao fenômeno do ñ̈os (ethos) musical da Antiguidade.

Aristóxeno prossegue na passagem em questão: "Todos os assuntos que forem estudados em um nível mais abrangente, a partir da arte das escalas e dos tons, não pertencem mais à Harmônica, mas àquele conhecimento que abarca essa ciência e outras, pelo qual são estudadas todas as partes da música. Essa é a conquista ( $\left.\varepsilon^{\prime} \xi ı \varsigma\right)$ do músico." (Meibom, 2, 1-5). Ou seja, apesar de ser "primeira na ordem", ela não compreende tudo, e mais, a totalidade da música só pode ser considerada a partir de um sujeito aqui incluído, o músico.

Contudo, é necessário observar que essa totalidade de que fala Aristóxeno não abarca aqueles assuntos que ocuparam a mente de seus antecessores pitagóricos e que constituem igualmente objetos da harmônica, ou canônica. Para o autor, não está em questão a causa das alturas musicais e de seus intervalos, o que importa é como elas se organizam em um sistema de escalas enquanto linguagem tonal. Já para os pitagóricos, com quem se inicia a ciência da Harmônica, a importância estava na origem primeira dos intervalos musicais, muito antes de sua organização em escalas ou de sua função no $\mu \varepsilon ́ \lambda$ ç. Eles estabeleceram uma expressão racional da 
matéria sonora, por meio da aritmética, sua principal ferramenta teórica, alinhada analogicamente à totalidade do cosmo. Essa corrente, nascida no século VI a.C., irá extrapolar o domínio da música gerando consequências importantes para a física acústica. A reconstituição de sua origem é feita a partir de fragmentos como os de Filolau e Arquitas e comentadores posteriores. No século III a.C., a obra Divisão do cânone, atribuída a Euclides, expõe de maneira ampla e sistemática a aplicação da matemática pitagórica à música.

Max Weber, como explica seu tradutor brasileiro Leopoldo Waizbort na introdução à obra, defendeu que "a autonomização da esfera artística engendra a legalidade própria dessa esfera, que é justamente a sua racionalização específica" (Weber, 1995, p.39). O pensamento pitagórico se processava por analogias, considerando, portanto, domínios extrínsecos à música para a sua explicação. Desse modo, poderia parecer paradoxal o fato de ele ser o ponto de partida do processo de racionalização da música ocidental e da sua caminhada rumo à autonomização. A aritmética, como instância extra-musical, foi determinante para o primeiro distanciamento em relação à matéria prima tonal, o som musical, o que não ocorria quando o $\mu \varepsilon ́ \lambda$ os estava mesclado à linguagem e ao ritmo, domínios não restritos à música, como já apontamos: a linguagem, mesmo poética, é fortemente referencial e o ritmo pode ser encontrado nos ciclos e fluxos da natureza.

No século III a.C., as duas correntes, aristoxeniana e pitagórica, serão vistas como antagônicas e essa dicotomia perpetuar-se-á nas discussões musicológicas medievais e renascentistas. Neste estudo, elas serão apresentadas com suas distinções, mas também como integrantes do mesmo quadro geral que tem como ponto de referência a natureza para construir os seus princípios; para descobri-los e demonstrá-los cada escola integra a Harmônica ora às ciências matemáticas, ora às ciências naturais ou 
físicas. E cada uma delas contribui a seu modo para o corpus teórico da música ocidental. O trabalho é delicado, haja vista que o alinhamento de posição dos pensamentos subjacentes às duas correntes sofre sucessivas inversões, talvez porque a música participe de maneira intensa de dois campos: o da ciência e o da arte. Isso faz dela um lugar privilegiado para observar as suas tensões.

Na dissertação, a opção pela via de investigação da Harmônica justifica-se por ter sido a partir dela que se iniciou propriamente 0 processo de racionalização do material sonoro, tal como enfatizado por Max Weber, ou seja, o fato de a música ter sistematizado seu material e seus meios levou-a a alcançar a autonomia de sua esfera de existência. Nesse processo, é também importante olhar para o desenvolvimento dos meios técnicos da música, como, por exemplo, seus instrumentos: "A racionalização dos sons parte historicamente e, de modo regular, dos instrumentos" (Weber, 1995, p.127), além das formas musicais, da notação e ainda dos instrumentistas e virtuoses.

A harmônica, dentre as disciplinas da música, foi a que se dedicou às questões de afinação dos instrumentos e das estruturas das escalas. Ao dedilhar a sua lira, era importante para o instrumentista grego saber que as cordas estavam afinadas adequadamente ao modo e gênero musical e ainda ao cantor que usualmente acompanhava. Os teóricos começaram a estudar e definir as múltiplas estruturas musicais gregas a partir das quais uma melodia poderia ser realizada e, ao fazer essa descrição, desenvolveram a linguagem própria da Harmônica.

$\mathrm{Na}$ dissertação, são incorporados elementos advindos da prática musical e da construção de instrumentos, pois, de fato, o pensamento sobre a arte em geral, e a música em especial, não está desvinculado da técnica - e da ciência - de seu tempo. Desse modo, será matizada a postura de alguns musicólogos e pesquisadores que consideram que, na Antiguidade, havia uma separação total entre a 
teoria e a prática musical, baseados em especial no argumento de que os escritos que chegaram até nós não oferecem nenhum trecho de música, nem fazem qualquer referência à prática musical ${ }^{4}$. Essa é uma dificuldade de fato; porém, serão feitos esforços para atenuá-la.

Algumas questões surgem no âmbito deste estudo. Por exemplo, os princípios da harmônica pertencem à natureza humana, a algo independente dela ou às duas instâncias? Consideramos que o som musical é essencialmente humano, visto que é produzido pela voz humana ou pelos instrumentos musicais. Contudo, assim que uma nota é gerada, entra em ação uma cadeia de ressonâncias físicas, a chamada série harmônica. Ela não é produzida deliberadamente pelo ser humano, mas em muitos momentos parece conduzir as suas escolhas musicais. Mas o padrão recorrente da série harmônica gerada pelo som musical, ou tom, insere-se no quadro geral da natureza, que nós, como parte dela, apreendemos.

As escalas musicais representam o primeiro grau de abstração da música, muito antes da verificação experimental da série harmônica, que só será feita no século XVII por Marin Mersenne. Podemos dizer que a música produzida desde a remota Antiguidade foi guiada pela percepção desses harmônicos, depois abstraída em escalas, muito antes dessa medição. Aristóxeno relacionou as propriedades do som musical à percepção humana, já os pitagóricos buscaram os padrões intrínsecos de sua estrutura.

4 Bélis, em seu artigo "L'harmonique comme science dans I'antiquité grecque", defende que teria havido um divórcio total entre as áreas prática e teórica na Antiguidade (1992, p.201-8). Contudo, no curso "De La Pierre au son: archéoéthnomusicologie de I'Antiquité Classique", ministrado de 14 a 30 de agosto de 2001 no Museu de Arqueologia e Etnologia da Universidade de São Paulo, atenuou sua posição, considerando que haveria uma hierarquia de valores, não uma separação absoluta. Já Barker considera que existia uma interação entre as partes: "sua relação [da harmônica] com a filosofia e as ciências naturais são mais distantes e suas interações com o mundo real do fazer musical mais próximo do que frequentemente se supõe" $(2007$, p.4). 


\section{CAPÍTULO I}

\section{MEIOS TÉCNICOS E ESTRUTURA DA MÚSICA GREGA}

\section{As origens musicais da harmônica}

O tom musical é um som discreto que se define pela relação intervalar que mantém com outros sons de alturas determinadas. Esses intervalos constituem o ponto de partida da Harmônica. Cada cultura encontrou seus intervalos musicais e os fez soar por meio das vozes, dos tubos de instrumentos de sopros, nas cordas, em instrumentos de percussão como litofones, xilofones e metalofones, até chegarmos à atual geração por dispositivos eletrônicos.

A contrapartida material dos instrumentos tem um papel crucial no desenvolvimento da teoria musical, ainda que não seja possível determinar de modo absoluto em quais situações um procedimento técnico faz avançar o campo artístico ou, vice-versa, se a necessidade estética antecede a busca por um avanço técnico, ou ainda, se são acontecimentos sincrônicos.

As distâncias intervalares são a base da afinação dos instrumentos. Em alguns casos, elas foram organizadas em sistemas de escalas, modos e gêneros. Os intervalos geram sensações ao serem ouvidos, descritas como prazer ou incômodo, suavidade ou estridência, doçura ou aspereza. De acordo com essas características,

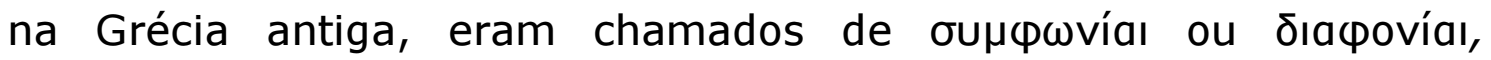
consonâncias ou dissonâncias ${ }^{5}$. O quanto a qualificação dos intervalos é um elemento cultural, ou não, transcende o escopo deste estudo;

\footnotetext{
${ }^{5}$ Os intervalos considerados consonantes eram os de oitava, quinta e quarta. Em uma escala musical ascendente com a nota dó como início, a oitava é a distância entre essa nota e o dó acima, a quinta entre o dó e o sol, e a quarta entre o dó e o fá. A nomenclatura das notas como dó, ré, mi, fá, sol, lá, si, dó surge na história da música somente na Idade Média, mas utilizo aqui para simplificar os termos gregos.
} 
contudo, muitos povos buscaram formas de definir com exatidão os intervalos musicais.

Entre as grandes civilizações anteriores ao período arcaico grego (800 a 500 a.C.), os chineses deram muita ênfase à precisão dos intervalos musicais, que estabeleceram possivelmente por volta de 2.600 a.C. a partir de uma sequência de bambus cortados em exatos intervalos de quinta, os tubos-diapasões lyu. Na Mesopotâmia, cerca de 3.000 a.C., os sumérios possuíam uma apurada técnica de construção de instrumentos. Ali, em um baixo-relevo das ruínas da cidade de Lagash, no sul do Iraque, está representado um músico tocando uma cítara aparentemente de 11 cordas. Os impérios assírio e babilônio, fundados por volta de 2000 a.C., foram fecundados pela civilização suméria. Nas escavações da cidade de Ur (também no Iraque) foram encontradas flautas, harpas, liras de 5 a 11 cordas, alaúdes e uma harpa de cordas percutidas por baquetas ${ }^{6}$.

Uma descoberta importante para a teoria musical foi a de três tábuas em escrita cuneiforme contendo um método de afinação de uma espécie de lira de nove cordas $^{7}$. A partir delas foi possível decifrar um sofisticado mecanismo de afinação alternando quartas e quintas consonantes com o objetivo de formar escalas que dividem a oitava em sete partes. Esse sistema mostrou-se semelhante ao grego, que talvez tenha aí a sua origem, mas o mais importante é que a descoberta das tábuas babilônicas apresenta a mesma predominância de quartas e quintas que se encontra na teoria e na prática musical do Ocidente.

Desde a Idade do Bronze, a península grega não era uma região isolada, mas fazia parte do complexo do mar Egeu, rota entre

\footnotetext{
${ }^{6}$ Ver, a esse respeito, Candé, 2001, vol. 1, p. 102-148.

7 As tábuas foram decifradas pela Profa. Anne Draffkorn Kilmer, do Centro de Estudos do Oriente Médio da Universidade de Berkeley, Califórnia, que descreveu a teoria da afinação babilônica em 1971: "The discovery of an ancient mesopotamian theory of music". In: Proceedings of the American Philosophical Society, ${ }^{\circ}$. 115, p. 131-149, apud Franklin, 2002, p. 441-442.
} 
o Egito e o Oriente Próximo, a leste, e a península itálica, a ocidente.

O povoamento grego na costa da Ásia Menor e das ilhas próximas iniciou-se por volta de 1050 a.C. As tradições da Mesopotâmia alcançaram as regiões da Síria e da Fenícia, depois a Ásia Menor e dali à Grécia. Além disso, entre 750 a 700 a.C, ocorreu a expansão do império assírio em direção a Ocidente no período conhecido como orientalizante. Entre os elementos culturais mesopotâmicos que penetraram mais profundamente na região egeana nesse momento estão os instrumentos musicais e suas formas de afinação.

\section{Os instrumentos musicais gregos}

Como já dissemos, a música grega era basicamente vocal e, portanto, ligada à poesia. Essa arte poético-musical era enfatizada e colorida por instrumentos de cordas, sopros e percussão.

Um dos instrumentos mais importantes para a cultura musical

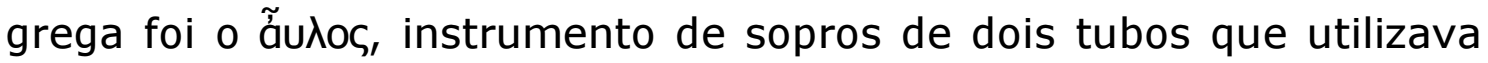
duas palhetas para produzir o som, tal como o oboé ou o fagote. Os tubos dos primeiros âu $\lambda$ o a apresentavam apenas quatro orifícios, então, era necessário trocar de instrumento de acordo com a escala em que a peça musical era executada. Ateneu narra, em sua obra Deipnosophistae, que foi Pronomus de Tebas "o primeiro a construir

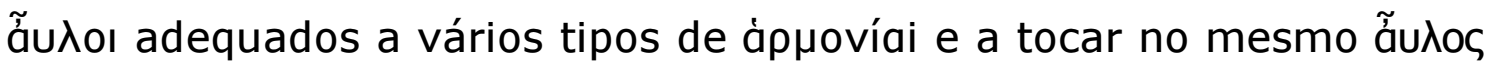
melodias diferentes. Diz-se que ele deleitava intensamente a audiência com suas expressões faciais e o movimento de todo 0 corpo" (631e apud Mathiesen, p. 184).

O ãu入oç demorou para ser aceito como um legítimo instrumento grego, como demonstram os mitos associando-o aos cultos de Cibele e Dioniso, deuses considerados originários da Ásia Menor. Aos poucos, ele foi ganhando espaço e, no século $V$ a.C., figurava como o instrumento da orquestra nas apresentações teatrais, possivelmente 
pela capacidade expressiva e também por sua potência de som. As competições auléticas foram importantes também para o desenvolvimento da música instrumental. O ãu內os possuía uma grande flexibilidade, possibilitando as sutilezas das múltiplas escalas descritas nos tratados musicais, e é possível que ãu $\lambda$ or duplos permitissem a execução de intervalos diferentes simultâneos, produzindo uma espécie de diafonia primitiva.

Aristóxeno, em Elementos de Harmônica, será um crítico da flexibilidade do ãudos devido à ausência de estabilidade de seus tons. A busca do tarentino na construção da ciência harmônica passará pela identificação de um conjunto de sons estáveis e organizados, condição do discurso científico, tal como para Aristóteles: "A aquisição inicial do conhecimento não ocorre pelo vir a ser; pois, de acordo conosco, a razão conhece e pensa por meio do repouso e da imobilidade" (Física, VII, 3, 247b 10-13. Apud Bélis, 1986). Para Aristóxeno, a harmônica não depende das propriedades de nenhum instrumento, especialmente o ãudoc: "ainda que se considerasse necessário reportar a melodia a um instrumento, não de deveria escolher o ãu入oc, porque não há que erro e incerteza na fabricação do

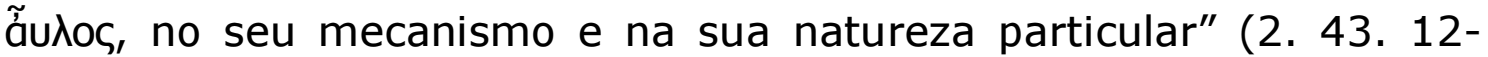
18).

Motivos similares levarão também Platão a colocá-lo na lista de instrumentos que deverão ser expulsos da sua Politéia. Além da própria característica variável do sopro que produz o som no ãu入oc, são documentados os movimentos de corpo e expressões faciais dos auletistas ao executarem as peças musicais, o que era acentuado pela própria dificuldade de execução do instrumento que, em peças

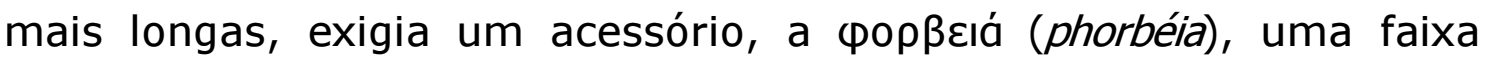
feita de pele de animal que acomodava o instrumento duplo. Em uma escultura de Praxíteles (por volta de 360 a.C.), está retratada a disputa na qual a música de Apolo, representada pela cítara, é 
julgada superior à do sátiro frígio Marsyas, esculpido nu portando um ãuגoc. Como perdedor, na história, Marsyas é enforcado e esfolado uma demonstração, esperamos, exagerada, de como os gregos levavam a sério a sua superioridade. Platão declara a preferência pelo instrumento de Apolo em relação ao de Marsyas (República, 399e). Antes, havia defendido que para os cidadãos é mais útil a lira e a

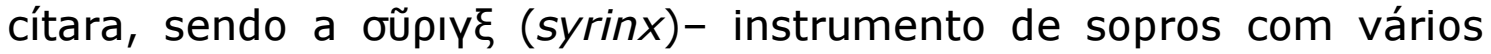
tubos parecido com a zampoña dos altiplanos andinos - mais adequada aos pastores nos campos (República, 399d).

Mas, embora visto com desconfiança pelo fato de ser um instrumento estrangeiro e, na verdade, por ter introduzido muita sofisticação às tradições sagradas dos gregos, o ãu入oc tornar-se-á um dos três instrumentos mais importantes do período clássico grego, junto com a lira e a cítara, participando do teatro, dos festivais, da educação e da vida cotidiana.

Ainda que os instrumentos de sopros e percussão fossem indispensáveis à música grega, a classe de cordófonos foi o seu fundamento, principalmente no que se refere à ciência musical. Essa ênfase nos instrumentos de cordas vai prevalecer no mundo ocidental quando o assunto for teoria e sistemas de afinação. No século XVII, Marin Mersenne, no "Primeiro livro dos instrumentos" de sua obra Harmonia universal, iniciará o estudo dos instrumentos musicais pelos instrumentos de cordas, considerando que eles "são mais simples e fáceis de compreender, pois as cordas representam as linhas e servem para explicar e demonstrar tudo o que pertence à música" (1986, p.2). Também Max Weber irá observar que "nas cordas há uma maior racionalização do sistema de tons" (1995, p.73). E a música ocidental terá de esperar até o século $X X$ para que os compositores concedam aos instrumentos de sopro e percussão 0 mesmo status daqueles de corda e teclado. 
Na Grécia, possuíam importância especial os diversos tipos de

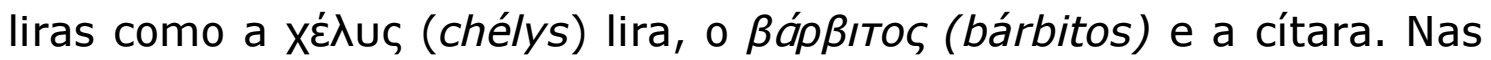
liras, as cordas são tocadas com um plectro, diferente dos psaltérios, ou harpas, que são dedilhados. As liras possuíam cordas mais ou menos iguais em comprimento, enquanto as harpas possuíam cordas graduadas. As cordas, em geral feitas de tripa de carneiro, não resistiram ao tempo, mas seu número nos instrumentos é bem documentado em fontes literárias e iconográficas, quando é possível observar a presença de cravelhas para uma maior precisão na afinação dos instrumentos. O aperfeiçoamento da cítara e também do ãu^os contribuiu consideravelmente para a expansão da música

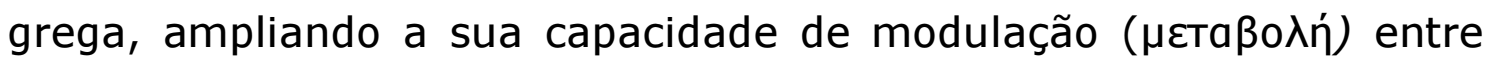
os modos.

\section{Aspectos da terminologia musical grega}

Em grego, a palavra tóvọ refere-se a tudo que produz tensão.

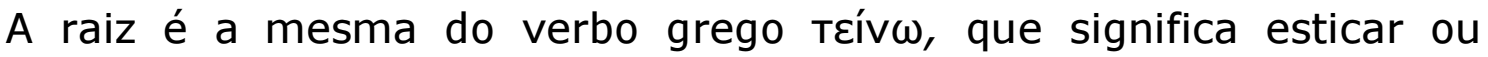
tensionar. Tóvos era também o tom musical que surgia no ato de esticar a corda de um instrumento, alterando um intervalo de quinta para quarta e marcando a diferença de tom entre ambas 8 .

Os nomes das notas ( $\varphi$ Өóyyo $\varsigma^{9}$ ) estavam diretamente relacionados a sua posição na corda e, até mesmo, ao dedo que a tocava, pois Xíxavos é o nome de uma nota e do dedo indicador. É bom relembrar que, no caso das liras, as cordas não eram dedilhadas e sim, tangidas por um plectro; portanto, essa terminologia talvez fosse oriunda dos instrumentos de cordas dedilhadas, da classe dos psaltérios. Para West, os nomes de outras notas também poderiam

\footnotetext{
${ }^{8}$ Ver, a esse respeito, West, 1981, p.119-120.

${ }^{9}$ O termo phtóngos é utilizado com múltiplos significados tanto na linguagem comum como na linguagem técnica musical com os sentidos de som, voz, fala, nota e altura musical.
} 
estar relacionados a sua posição: mése ( $\mu$ éon) seria referente ao dedo médio e tríte (трі́тп), ao terceiro dedo, anular (Cf. 1981, p.1201). Essa concepção enfatiza a perspectiva de uma origem material para o sistema grego em tetracordes, sequências de quatro notas, em que cada nota corresponderia a uma corda do instrumento. De qualquer modo, a forma de nomear as notas era diferente das que conhecemos hoje. Nossa nota dó é um tom específico - ou frequência, em linguagem moderna. Já as notas gregas referiam-se a uma posição dentro do tetracorde ou do instrumento.

Outros termos musicais estariam associados à prática instrumental, por exemplo, a oposição entre tom "alto" (a̋v $\omega$ ) e "baixo" (ка́т $\omega)$. Inversamente ao que estamos acostumados hoje, o primeiro referia-se ao som mais grave e o segundo, ao mais agudo. Isso porque mais "alta" era a corda mais distante do instrumentista em posição de execução da lira ou da harpa, e vice-versa.

Essas denominações advindas da prática instrumental muitas vezes não eram acolhidas por teóricos como Aristóxeno. Como observa Bélis, "Aristóxeno não utiliza os termos alto (ảv $\omega$ ) e baixo

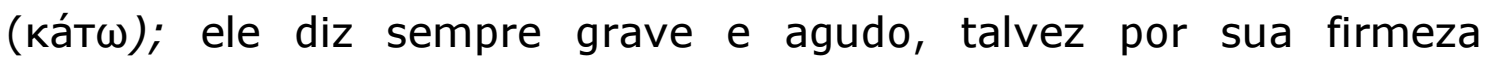
doutrinal: repugnar-Ihe-ia trazer emprestado denominações da prática instrumental, uma vez que se recusava a tomar por critério de julgamento tanto o ãu入os como a lira" (1986, p.136).

\section{As cordas e a estrutura musical grega}

Franklin (2002, p.444) defende que teria havido, no início da era arcaica grega, um confronto entre a poesia épica, cantada com a lira de quatro cordas, e a poesia lírica, cantada com a lira de sete cordas. Essa transição entre os dois gêneros poéticos é significativa nos poemas homéricos, elaborados provavelmente por cantores profissionais que se apresentavam nos festivais. Sua forma definitiva 
ocorre no período arcaico, mas eles pertencem ainda à tradição anterior, épica aristocrática, e mantiveram a métrica e a forma do gênero literário. Cada poema era dedicado a um deus do panteão grego. No poema dedicado a Hermes, o poeta conta como o deus "inventou" a lira de sete cordas para dar de presente a Apolo, o deus da tradição épica. No hino, são descritos detalhes da construção da lira, o material utilizado (casco de tartaruga - xéduৎ -, couro de boi, cordas de tripa), assim como a forma de execução com o plectro.

Essa interpretação de que a lira do período épico teria quatro cordas é contestada por estudiosas como Martha Maas e Jane McIntosh Snyder, que descreveram detalhadamente os instrumentos de cordas gregos. De acordo com as autoras, "o número de cordas nos instrumentos do tipo lira, desde as liras minóicas antes do século

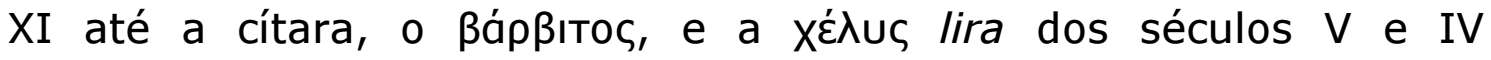
provavelmente permaneceram as mesmas" (1989, p. xvi). Para elas, o número de cordas que aparece nas iconografias está ligado ao material empregado, ao espaço disponível para a reprodução no artefato e ao grau de realismo do artista. A confusão teria sido criada pela interpretação influente do escritor alemão $L$. Deubner ${ }^{10}$ que viu num poema atribuído a Terpandro, poeta lírico do século VII a.C.

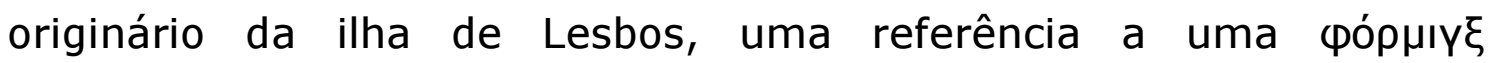
(phomínx $)^{11}$ de sete tons oposta à de quatro: "Colocando de lado a canção (áoıঠ́n) de quatro vozes, cantaremos novos hinos em uma

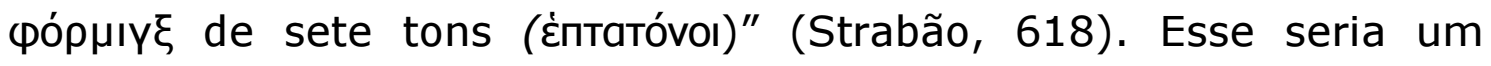
clássico erro de interpretação a partir de uma única fonte literária e

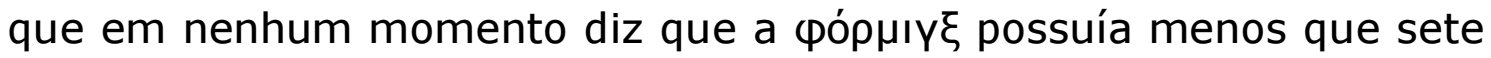
cordas. Além disso, é preciso atentar para o fato de que na literatura

\footnotetext{
${ }^{10}$ A argumentação do autor está em Deubner, L., "Die viersaitige Leier", Athenische Mitteilungen 54 1929, 194-200. e Deubner, L., "Terpander und die siebensaitige Leier", Philologische Wochenschrift 50 1930, 1566-1567.

${ }^{11}$ A phóminx é uma espécie de lira. Os instrumentos tipo lira possuíam cordas mais ou menos do mesmo tamanho, já os do tipo harpa, cordas de comprimentos graduados.
} 


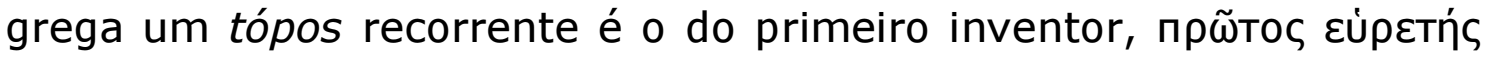
(protos euretes). Concluindo, a lira de sete cordas pode ter existido desde a Guerra de Tróia até o tempo de Alexandre, o Grande.

De qualquer forma, os tetracordes foram o núcleo da música grega e é certo que Terpandro acompanhava-se de um instrumento de sete cordas. ${ }^{12} \mathrm{~A}$ lira de sete cordas possibilitou ao músico ampliar a execução musical até uma oitava entrelaçando dois tetracordes. $O$ texto aristotélico Problemas Musicais registra que foi Terpandro quem afinou a lira de sete cordas, de modo que ela abrangesse uma oitava,

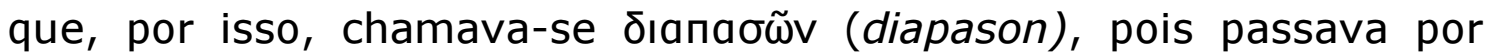

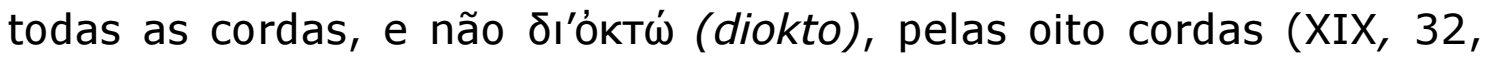

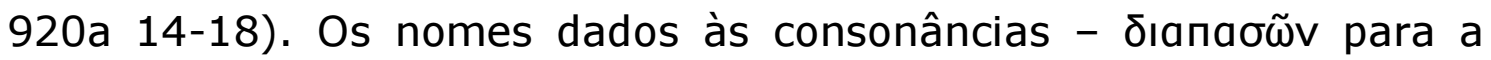

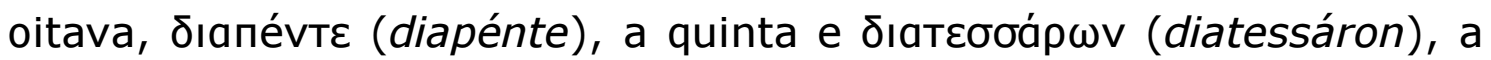

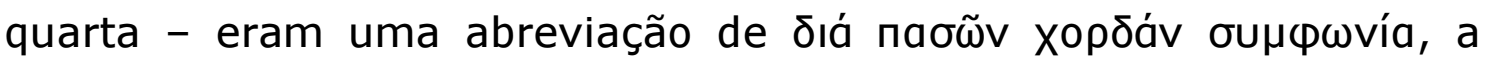

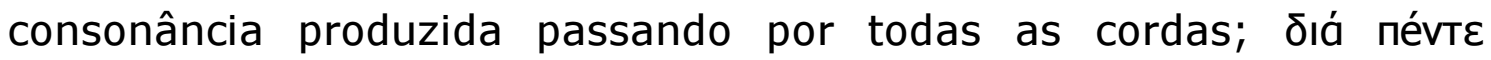

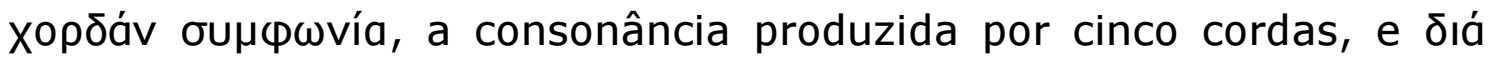

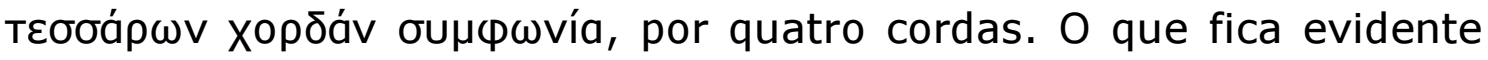
nessa terminologia é que os instrumentos de cordas eram afinados a partir dessas consonâncias e, mais do que isso, elas eram a própria referência para a afinação.

O número de cordas ultrapassava a simples busca por um efeito sonoro, relacionando-se com a estrutura de todo o sistema. Os heptacordes teriam evoluído para octocordes. De acordo com os Problemas aristotélicos, a prova de que antes a escala era heptacorde é a denominação da nota $\mu$ éon, média. Como poderia haver uma nota média em oito cordas se o número oito não tem meio? A denominação $\mu$ éon, portanto, viria de uma escala heptacorde (XIX,

12 Plutarco (cerca 50-120d.C.), em sua obra De musica, narra que Terpandro ficou conhecido por ter feito uma inovação na lira homérica, aumentando o número de cordas de quatro para sete. Apud Mathiesen, 1999, p. 243. 
25, 919b 20-22). ${ }^{13}$ Essa afirmação enfatiza uma concepção aritmética do sistema e parece anular a hipótese de West de que a denominação

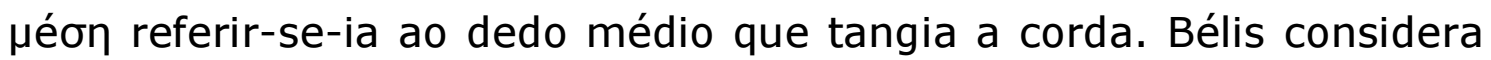
que a conclusão aristotélica, no entanto, é uma prova de que os teóricos estavam afastados da prática musical e que, ao buscarem construir seus sistemas, ficavam confusos com a terminologia advinda da prática (Bélis, 1986, p.136-137).

Para Winningtom-Ingram, mais importante que determinar a origem do termo $\mu$ éon é perceber que ela funcionava como um centro tonal da melodia. Ele considera plausível a hipótese de que o tetracorde primitivo tenha se desenvolvido para um heptacorde, por meio do encaixe de dois tetracordes: "se no tetracorde sozinho a nota superior da quarta atraía a atenção sobre si, dentro do heptacorde, a

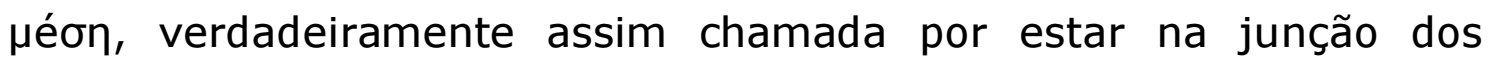
tetracordes, era o foco da melodia. Mais tarde, a consonância da oitava foi percebida e o heptacorde tornou-se um octocorde. A tendência melódica descendente (tal como podemos postular para a música primitiva) fez com que o tetracorde superior fosse alcançado a partir do limite superior [ou seja, saltando para a oitava e descendo] o que levou a criar um tom disjunto entre os tetracordes" (1968, p.26).

Em algum momento, portanto, dois tetracordes foram separados por um tom inteiro, possivelmente com a inserção de mais uma corda musical na lira. O importante é que essa corda, ou esse tom, foi inserido entre os tetracordes, e não em uma das extremidades da escala musical. E essa alteração teve consequências profundas na teoria musical grega. A oitava passou a ser percebida e considerada o ponto de partida da teoria musical, dividida em dois intervalos desiguais: uma quarta e uma quinta. O sofisticado sistema

${ }^{13}$ Nicômaco de Gerasa, no Manual de harmônica, cap. V, narra que Pitágoras teria colocado uma oitava corda na lira criando a escala de oito notas. 
de modos gregos (àpuovíai) organizou-se a partir das posições desses intervalos.

Podemos ver a escala octocorde, de oito notas, como a reunião de dois tetracordes como um tom no meio ou, como prefere Del Grande, "um tetracorde mais um pentacorde" (1960, p.406). As notas extremas eram então vท́тn (néte), a nota mais aguda, e únátn (hypátes), a mais grave, formando um intervalo de oitava. A vท́тп era a corda que ficava mais próxima do instrumentista na posição de tocar a lira, a cítara ou a harpa. únátns era a mais distante. As escalas eram organizadas de modo descendente e, portanto, a partir

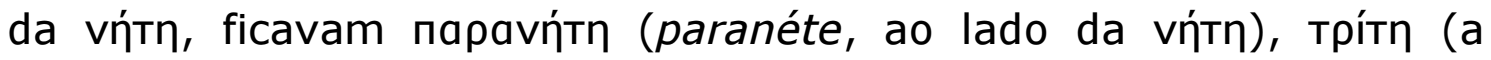

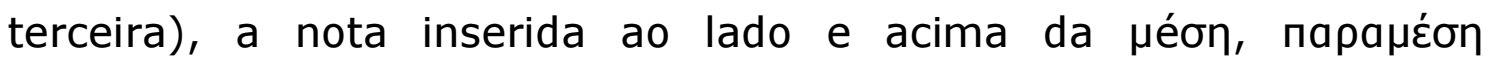

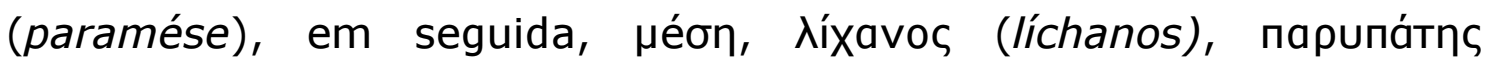
(parypates) e únátns.

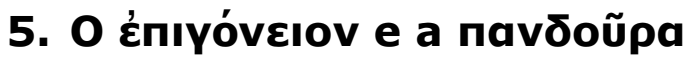

No período clássico, as liras estiveram na base da educação musical grega, levando os cidadãos a um alto nível de exigência crítica em relação a seus executantes. O tipo de lira preferido pelos profissionais era a cítara, com sua ampla caixa de ressonância. Ela era utilizada pelos citaredos, combinação das palavras cítara e aedo, cantores.

Os psaltérios, ou harpas, possuíam grande número de cordas e eram tocados por virtuoses que provavelmente começaram a desenvolver uma música instrumental, tal como os auletistas. De acordo com Mathiesen (1999, p.270), alguns tipos de harpas parecem ter sido exclusivos das mulheres e é possível que esses instrumentos estivessem também associados aos cientistas musicais que surgiram no século VI a.C. $O$ Énıyóveıov possuía 40 cordas e era tocado com o instrumento na posição da harpa atual, em pé. $O$ nome 
adveio de seu construtor, Epígono de Sycion, mencionado por Aristóxeno (Meibom,3,20-24) como um músico-téorico que, junto com Lasos de Hermíone, achava que o som musical possuía largura.

Mathiesen aponta o fato de que o autor grego Atheneu, na sua obra Deipnosophsitae, comenta que a escola de Epígono era conhecida por sua música complexa, dramática e expressiva e que o estilo foi adotado por citaristas que, entre outras coisas, passaram a esticar mais as cordas para alcançar uma intensidade maior de som.

Na mesma passagem, Mathiesen observa que o termo utilizado

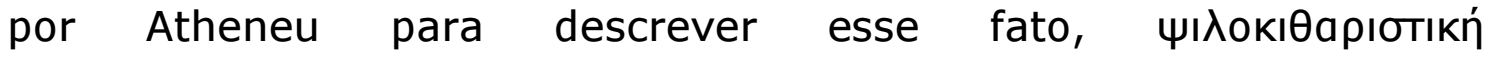

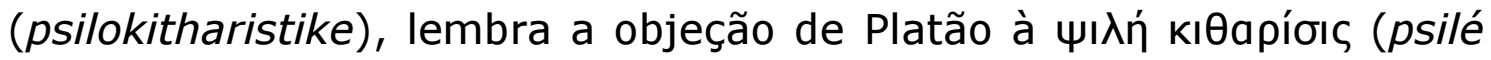
kithárisis) na sua discussão sobre a mímesis na obra Leis. Ali, Platão rejeita a música puramente instrumental, considerando que o texto é essencial para a mímesis: "e eles usam música solo de cítara e ãu入oৎ, que é difícil de entender sem um texto para compreender a intenção do ritmo e da melodia e com qual dos modelos eles se parecem. Mas é preciso perceber que a coisa é também cheia de grosseria. Pelo fato de serem excessivamente amantes da velocidade, das minúcias e dos sons bestiais, eles praticam o ãu入os e a cítara sem dança ou canção. Qualquer pessoa que utilize um dos dois instrumentos solo é dado a

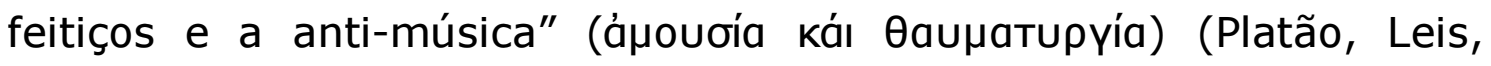
669d-670a. Apud Mathiesen, 1999, p.270).

Outro instrumento de cordas que surgiu na música grega vindo do Oriente foi a navঠooũpa, da classe dos alaúdes. Surpreendentemente, apesar de haver indícios da presença desse tipo de instrumento no lado oriental do Mediterrâneo, sua representação nas figuras e relevos gregos que chegaram até nós, só ocorre no período das campanhas persas de Alexandre, em torno de 330 a.C. Parece que o instrumento, chamado também de skindápsos

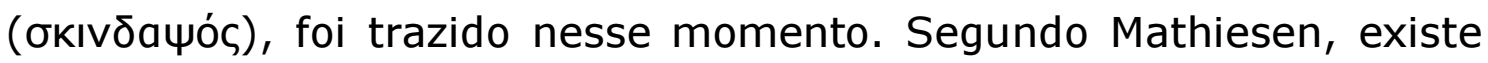
ainda uma referência de Pólux, em seu livro Onomásticon, de que a 
pandora havia sido inventada pelos assírios e que possuía três cordas. Para o autor de Apollo's Lyre, o braço da pandora era trasteado, as cordas eram três e o instrumento possuía algumas vantagens sobre as liras: "Um instrumento com braço trasteado poderia facilmente produzir com grande precisão muito mais tons em três cordas do que qualquer instrumento multicordas. Além disso, por possuir apenas três cordas, era mais fácil afinar e sua afinação como um todo seria mais estável" (1999, p.285).

Esse tipo de instrumento certamente era mais propício à descoberta dos princípios matemáticos na música, pois a afinação seria feita por divisão da corda, algo impossível na lira. No entanto, o instrumento teve papel inexpressivo na cultura musical grega. Seria por sua pequena intensidade sonora comparando-se às cordas que vibravam mais livremente e à grande caixa de ressonância da cítara? É possível que os gregos, aficionados das grandes apresentações ao ar livre, não achassem o instrumento adequado a suas competições e festivais. Outra hipótese é a dificuldade de mudança de todo um sistema que, como vimos, apoiava-se nos instrumentos de cordas do tipo lira e harpa.

Curiosamente, a classe das liras não se desenvolverá na história da música ocidental, ficando restrita à música dos povos africanos e asiáticos. Já os instrumentos do tipo psaltério, como a harpa, e os do tipo alaúde terão uma longa trajetória no Ocidente. O alaúde passou por inúmeras reformas no mundo árabe e, mais tarde, brilhou no período renascentista europeu, tendo sido importante para os avanços da ciência musical. Vincenzo Galilei era alaudista e discutiu questões de afinação a partir de seu instrumento. Marin Mersenne, no Segundo livro dos instrumentos da sua obra Harmonia Universal, dedicado mais amplamente a questões de afinação, inicia o trabalho pelo estudo detalhado do alaúde. 


\section{Afinação e gêneros musicais}

A prática de afinação dos instrumentos de sete, oito ou mais cordas gregos provavelmente assemelhava-se ao mecanismo babilônico mencionado anteriormente, partindo das consonâncias de quartas e quintas. Os músicos conhecem a praticidade desse tipo de sistema, registrada por Aristóxeno: "nossa percepção é mais confiável no que diz respeito aos intervalos de tamanhos consonantes que dos não consonantes e a afinação dos intervalos não consonantes será mais precisa quando for alcançado através de uma consonância" (Meibom, 55, 4-7). Esse processo de afinação era chamada de n̆ $\lambda \dot{\psi} \psi ı \varsigma$

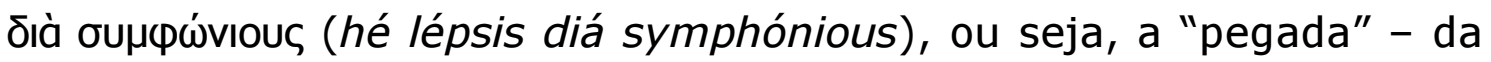
afinação - pela consonância. Aristóxeno mostra como se obtém os

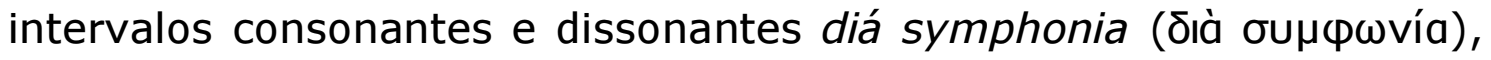
ou seja, por meio das consonâncias (Meibom, 55, 14-19).

Max Weber associa essa escolha das consonâncias de oitava, quinta e quarta por um grande número de culturas com a facilidade de fixação pela memória: "O que distinguia, para o desenvolvimento da tonalidade primitiva, os intervalos harmonicamente mais puros oitava, quinta, quarta - das outras distâncias era, em geral, a circunstância de que eles - uma vez "reconhecidos" - salientaram-se de modo acentuado, por sua maior clareza, do conjunto das distâncias sonoras vizinhas; salientaram-se para a memória musical" (Weber, 1995, p. 85).

No sistema musical grego, os intervalos consonantes irão tornar-se fixos, e os dissonantes mutáveis de acordo com o gênero. A classificação dos gêneros musicais era definida pela distribuição dos intervalos nos tetracordes que, por sua vez, formavam as escalas ou os modos. Esses modos podiam organizar-se em tóvol a partir de transposições. 
No gênero diatônico, o tetracorde era dividido em dois tons e um semitom. Os outros dois gêneros, cromático e enarmônico, apresentavam distâncias de tom e meio e meio-tom (cromático) e de dois tons e quarto de tom (enarmônico). Aristóxeno vai considerar o gênero diatônico o mais "natural": "o diatônico deve ser considerado o primeiro e mais antigo, pois a natureza do homem o conduziu a ele primeiro, depois ao cromático e, por último, ao enarmônico, que é o último com o qual a nossa percepção acostuma-se e depois de muito esforço" (Meibom, 19, 14-17).

Em outro trecho da obra, no entanto, o autor discorre sobre os "antigos modos de composição" (Meibom,23,7-9) exemplificando-os com a estrutura do gênero enarmônico, ao qual chama de "o mais belo" (Meibom, 23, 4) ${ }^{14}$. Podemos atribuir a pequena confusão ao fato de não existir ainda uma concepção de abordagem rigorosa da história da música, a qual Aristóxeno também inaugurava. De qualquer modo, sua preocupação, ao definir a ciência do $\mu$ ćरo૬, era estabelecer pontos fixos e, para tal, o gênero diatônico era exemplar. O enarmônico, que compreendia quartos de tom, apresentava dificuldades e não irá subsistir no Ocidente. A afinação proposta pelos pitagóricos também estava centrada no gênero diatônico, mais homogêneo e simétrico. Essa ênfase correspondia tanto à simbologia matemática quanto aos interesses de transposição das melodias, que era facilitada pela maior igualdade das distâncias intervalares.

No século IV a.C., as escalas abrangiam quinze ou onze tons. $O$

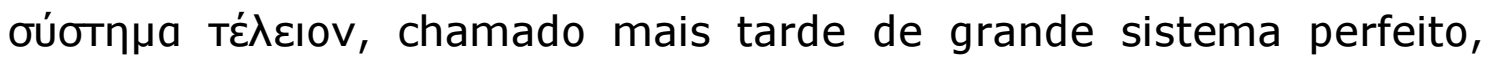
apresentava quinze notas dispostas em quatro tetracordes

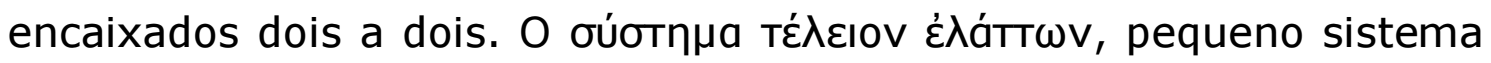
perfeito, era constituído de onze notas dispostas em três tetracordes conjuntos.

${ }^{14}$ Ver, a esse respeito, Rosetta da Rios (1954, p.34, nota 2). Del Grande cita o Fragmento W.85 de Aristóxeno, no qual ele reconheceria também a anterioridade do gênero enarmônico (1960, p. 402). 
Quando iniciamos o estudo da música grega da Antiguidade, chama a atenção a inexistência de uma transmissão direta, que ocorreu em outras civilizações de cultura musical muito antiga e altamente sofisticada, como a da Índia, por exemplo. A música grega e os instrumentos musicais de época tiveram de ser reconstituídos por meio de estudos empreendidos por especialistas em refazer os parcos papiros, decifrar a escrita musical em muros ou em fragmentos esparsos. E isso só teve início no século XIX.

Com o desenvolvimento da escrita alfabética, no século $V$ a.C., os antiquíssimos poemas homéricos foram cristalizados no aspecto visual da letra. Os jovens estudantes de música seguiam aprendendo de memória, sem fazer uso da escrita. Os profissionais contratavam os melógrafos que se encarregavam da escrita musical. A escrita musical facilitava o intercâmbio nessa época em que era grande a curiosidade, por exemplo, em saber qual a última ária de Eurípides; por outro lado, fez ruir o processo de transmissão oral, e a música praticada na Grécia ficou restrita a frágeis suportes sujeitos às intempéries do tempo. Os fragmentos de escrita musical grega que sobreviveram estão basicamente relacionados ao teatro e à poesia. A música instrumental, por ser mais complexa e mais virtuosística, quase não foi preservada.

Assim, a música grega praticamente desapareceu no contato com a força do Cristianismo, que, no entanto, manteve a tradição dos modos sistematizados apesar das conhecidas - e talvez deliberadas alterações nas denominações dos modos. Os padres da Igreja talvez tivessem em alta consideração as recomendações de Platão e Aristóteles sobre o poder da música e inverteram os modos pagãos, esperando, assim, inverter os mundos.

Mas se a música grega permanece enevoada pelo tempo, o mesmo não aconteceu com a ciência musical grega, que influenciou radical e silenciosamente a música ocidental como um todo. O início 
ocorre com Pitágoras, cujos experimentos lançaram os fundamentos de toda a especulação físico-matemática da música do Ocidente, muito embora a redução da música à matemática tenha colocado problemas para serem resolvidos pela teoria musical subsequente. 


\section{CAPÍTULO II}

\section{AS ORIGENS MATEMÁTICAS DA HARMÔNICA}

\section{As disciplinas matemáticas}

No século VI a.C., ocorre a primeira explicação matemática dos

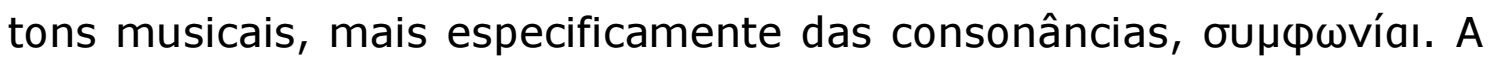
descoberta, que se deu no âmbito da escola pitagórica, marca o início da harmônica, mas os estudos são dificultados tanto pela falta de documentos quanto pelo excesso de lendas e anedotas sobre Pitágoras (c. 580/78 - 497/6 a.C.). O legado da escola pitagórica é reconstituído a partir de alguns poucos fragmentos do século $V$ a.C., textos dos séculos IV e III a.C. e comentadores posteriores.

As especulações sobre a natureza empreendidas pelos primeiros pitagóricos eram puramente matemáticas. Por exemplo, nos sistemas astronômicos que desenvolveram, tudo se movia em um espaço geométrico perfeito: os corpos celestes eram descritos como esferas que se moviam em círculos, figuras e movimentos matematicamente perfeitos. Como observa Thomas Heath, a astronomia pitagórica "é pura matemática, é geometria combinada com aritmética e harmonia (...). As matemáticas pitagóricas, portanto, são uma ciência única, e a sua ciência é toda matemática" (1981, p.165).

Esse corpo de disciplinas estava entrelaçado pela concepção de número, formando um grupo denominado na Antiguidade de ciências irmãs. Uma das referências mais antigas a esse conjunto está no fragmento da obra Harmonia de Arquitas de Tarento (c. de 400 a 365 a.C.): "De fato, sobre a velocidade dos astros, sua ascensão e declínio, transmitiram-nos (os matemáticos) claros conhecimentos; 
também sobre geometria, ciência dos corpos celestes e não menos sobre música. Pois essas ciências parecem ser afins; pois se ocupam de coisas afins: as duas formas primeiras do ser" (DK 47, B 1).

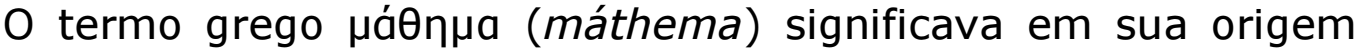
estudo, conhecimento. Para os pitagóricos, o conhecimento estava diretamente relacionado à ciência dos números. A música era considerada uma das matemáticas por se ocupar das razões e das proporções numéricas. É esse sentido original que está presente na obra de Platão, onde aparece pela primeira vez o termo harmônica, no neutro plural grego tá ápuovıká (Cf. Barker, 2007, p. 6, nota 1). No diálogo Fedro, Sócrates explica que saber se uma corda é mais grave ou mais aguda faz parte da $\mu a ́ \theta n \mu a$ necessária, ou seja, do aprendizado necessário ao estudo da música. Mas para que alguém seja verdadeiramente músico, deve conhecer tá à $\rho$ ovı́á $(268 e)^{15}$.

No período clássico, as disciplinas matemáticas estarão integradas à educação básica. No diálogo platônico Teeteto, Sócrates questiona o jovem Teeteto sobre as disciplinas que aprende com seu professor Teodoro. Teeteto afirma que estuda as quatro disciplinas matemáticas - geometria, astronomia, música (àpuovías) e

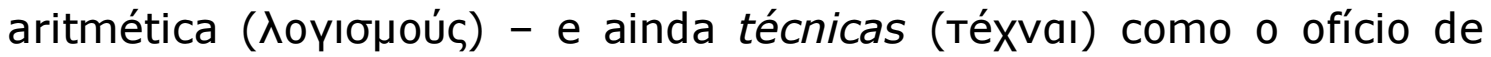
sapateiro e outros (145a-d). Em Leis, a ideia de tría mathémata (трía наӨńната) surge mais definida (817e, apud Heath, 1981, p. 19). Seria o grupo da aritmética, geometria e astronomia. No Epinomís é acrescentada a música (990c-991a).

No livro Timeu, Platão descreve como a alma do mundo tece o

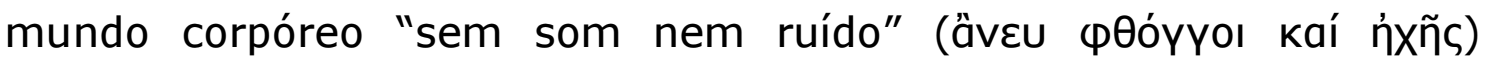
(Timeu, 37b). A narrativa terrificante descreve essa música teórica, irmã da astronomia teórica, tal como apresentadas por Sócrates no Livro VII da República: "tal como os olhos fixam-se na astronomia,

15 No trecho do Fedro em questão, o músico diria ao não músico: "Conheces o estudo básico da harmonia, mas não a harmônica" (all'ou tá harmoniká). 
assim os ouvidos fixam-se no movimento harmônico, essas duas ciências são irmãs, tal como dizem os pitagóricos, e nós concordamos" (530d).

Platão defendia que deveríamos nos concentrar não nas estrelas e seus movimentos, mas no céu abstrato da matemática, ou seja, não só na beleza do céu, mas na beleza da teoria que os astros imitam. A astronomia estuda o movimento dos corpos, já o movimento harmonioso ocorre a partir das leis da harmonia. Contudo, esse movimento harmônico não é uma referência aos movimentos dos tons no tempo, nem ao ritmo, mas a uma ideia imanente do som musical, em que cada tom possui uma velocidade de movimento determinada.

Na filosofia aristotélica haverá uma primeira ruptura com essa concepção de ciência exclusivamente ligada às matemáticas. No segundo capítulo do Livro II da Física, Aristóteles faz a distinção entre as disciplinas físicas e matemáticas: os objetos matemáticos podem ser estudados de maneira abstrata, mas não os corpos naturais ou físicos, que devem ser investigados pela física.

Aristóteles observa, no entanto, que existem ciências que trabalham com objetos naturais, de maneira matemática, como acontece com o som musical: "isso aparece nas mais físicas dentre as matemáticas: a óptica, a harmônica e a astronomia, pois, de certo modo, elas se comportam de maneira inversa à geometria; pois a geometria estuda a linha física, mas ela não é física - ao contrário, a óptica estuda a linha matemática, não enquanto matemática, mas enquanto física" (Física, II, 2, 194a 7). É conhecida a posição de Aristóteles no que diz respeito à contestação do pitagorismo. Mas suas objeções referem-se à metafísica e à astronomia; no que tange às razões pitagóricas, ele estava de acordo que elas fossem os princípios dos intervalos musicais e das consonâncias. Isso fica evidente em algumas das questões presentes na obra aristotélica 
Problemas, Livro XIX, dedicado à música, em que muitos problemas são resolvidos de maneira matemática.

No final do século IV d.C., o autor romano Boécio, em sua obra Instituições musica incluirá a música no grupo de ciências do quadrivium, aquelas que lidam com o número, estabelecendo uma oposição com o que chamou de trivium, que representava as ciências da linguagem: lógica, gramática e retórica ${ }^{16}$. A música foi dividida em três partes - musica mundana: a harmonia das esferas, dos elementos e das estações; musica humana: harmonia da alma; e musica in instrumentis constituta, que era a música produzida pela voz e pelos instrumentos musicais. Essa divisão criava uma hierarquia de valores e aprofundou a divisão entre a especulação teórica da música e sua prática. Em um eco da filosofia platônica, para Boécio, apenas aquele que conhecia os princípios da musica mundana poderia ser chamado musicus.

Essa busca pela "verdadeira ciência" produzirá efeitos colaterais negativos - flagrantes na prática musical - pois tão logo o que é simples e ideal interage com a multiplicidade, instauram-se os conflitos. O encaixe harmônico entre os dois mundos não está dado. Um exemplo disso ocorrerá no século XVI, quando um problema técnico de afinação levará à contestação de todo o pensamento subjacente à teoria musical pitagórica.

\section{As razões numéricas musicais}

Pitágoras nasceu na ilha de Samos, um dos povoamentos gregos na costa da Ásia Menor. A partir dessa posição geográfica privilegiada, há relatos de que ele teria visitado o Egito, a Mesopotâmia e mesmo a Índia, até transferir-se, por volta dos seus

${ }^{16}$ O quadrivium reunia a aritmética, que trabalha com o número em si mesmo; a geometria, com as magnitudes imóveis; a astronomia, com as magnitudes móveis, e a música, com as razões e proporções. 
50 anos, para o ocidente grego (Cf. Jâmblico, 2003, p. 29-36.). Tanto a matemática egípcia quanto a babilônica utilizava como constitutiva da ideia de número o conceito de frações como representação das divisões de um todo. Contudo, na Grécia, uma fração era vista como uma razão, ou seja, uma relação entre números inteiros. Como explica Boyer, "um tal ponto de vista, que focaliza a atenção sobre a conexão entre pares de números, tende a por em relevo os aspectos teóricos do conceito de número e a reduzir a ênfase no papel do número como instrumento de cálculo ou de aproximação de medidas" (1999, p.36).

O ponto de partida da Harmônica ocorre justamente quando as consonâncias são descritas como relações entre números ou razões numéricas: $2: 1$, a oitava; $3: 2$, a quinta e $4: 3$, a quarta ${ }^{17}$. A teoria é atraente por sua beleza e simplicidade, pois desvela com os quatro primeiros números o fato das consonâncias serem agradáveis ao ouvido.

Com a tradução do som musical, mais precisamente, dos intervalos musicais, em razões numéricas, Pitágoras ou os pitagóricos descobriram as mais antigas leis quantitativas da acústica e, talvez, da física matemática: a proporcionalidade inversa entre a altura e o comprimento de uma corda vibrante. Teria a descoberta partido de uma observação empírica? E se a resposta for afirmativa, em que tipo de aparato científico ou instrumento musical foi feita a observação? Ou teria partido de uma hipótese absolutamente teórica? De qualquer maneira, as razões numéricas realizaram uma síntese que, para os pitagóricos, confirmava a existência de uma analogia entre a harmonia e toda a natureza por meio de um princípio de unidade e coesão: o número.

17 A atribuição desse feito a Pitágoras é dada não só por seus seguidores, mas também por representantes de outras escolas. Ver Delatte (1974, p. 258). 
O discurso pitagórico tinha também caráter sagrado. Um aspecto que costuma ser relacionado à descoberta das razões das consonâncias é de origem simbólica. Os números $1,2,3$ e 4 formavam a тєтрактús, uma das partes essenciais da aritmologia pitagórica. А тетрактús era considerada o princípio organizador do cosmo. Várias analogias eram estabelecidas a partir dela. $\mathrm{Na}$ natureza, as coisas estariam dispostas em conjuntos de quatro. Era possível desenhar o primeiro sólido com quatro pontos no plano. A soma dos quatro primeiros números resulta no número dez, considerado perfeito por vários motivos, por exemplo, por reunir as quatro dimensões: um: o ponto; dois: a reta; três, o triângulo e quatro, o primeiro poliedro, o tetraedro. É difícil saber exatamente como esse simbolismo místico impulsionou a descoberta das razões das consonâncias mas a тєтрактúc talvez possa ser considerada a chave da descoberta das leis acústicas dos intervalos musicais. A coincidência das razões dos quatro primeiros números com a harmonia consonante confirmava a aritmologia pitagórica, que determinou, dessa forma, o caminho da ciência musical do Ocidente.

\section{A coesão harmônica da natureza}

A primeira fonte escrita que chegou até nós dessa proto-ciência pitagórica são os fragmentos do livro Sobre a natureza, de Filolau de Crotona, que viveu aproximadamente de 470 a 385 a.C., na cidade de Crotona, sul da Itália, onde floresceu a escola pitagórica e na qual, de acordo com a tradição, viveu o próprio Pitágoras. Segundo Diógenes Laércio, Filolau foi identificado por Aristóxeno - que tinha conexões fortes com os pitagóricos, pois seu pai pertenceu à escola como sendo da última geração de pitagóricos (D.L. VIII 46, apud Huffmann, 2005, p.2.). Nos fragmentos de Filolau, encontramos 
também temas comuns à filosofia pré-socrática, como o conceito de harmonia.

$\mathrm{Na}$ filosofia de Empédocles de Agrigento (c. 490-435 a.C.), àpuovía é um princípio de coesão dos elementos e tem seu oposto em vẽ̃kos (neíkos) princípio de separação e destruição. Para Heráclito de Éfeso (c. 540-470 a.C.), o elemento contrário é parte da estrutura harmônica: "não compreendem como o divergente consigo mesmo concorda; harmonia de tensões contrárias como a do arco e da lira" (DK 22 B - 51). A palavra grega naגívtovos (palíntonos), traduzida aqui pela expressão de tensões contrárias, enfatiza a noção de simetria de tensões, presente no termo àpuovía que, até hoje, traz subjacente essa concepção de equilíbrio de forças.

A raiz grega da palavra harmonia, >har, define um campo semântico relacionado às ações de ajustar, articular, encaixar. O substantivo àpuós (harmós), portanto, pode ser traduzido por articulação, junção, encaixe e pertence também à esfera da visão e do tato como palavra técnica utilizada por carpinteiros e construtores. Para alguns autores essa seria sua primeira acepção, só depois passando a integrar o campo da acústica (Spitzer, 2009, p. 160, nota 8). Entre os vários empregos na música grega, àpuovía é um sistema de afinação, no qual o músico "encaixa" auditivamente um padrão de notas no momento em que afina o instrumento.

No primeiro fragmento da obra Sobre a natureza, de Filolau, encontra-se uma definição de natureza baseada na harmonia: "a

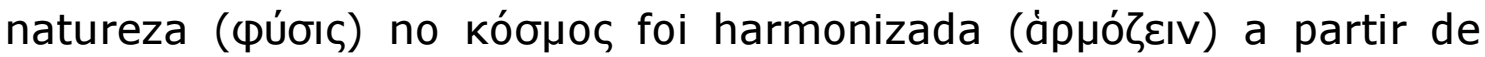

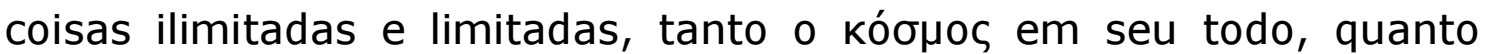
tudo que há nele" (DK 44 - B-1). É um tópos da filosofia pré-socrática - questionamento acerca dos princípios da natureza, além de concebê-la como ordem; a sua constituição se dá a partir de elementos como água, fogo, ar, ou de pares como quente/frio, denso/rarefeito. Também o par limitado/ilimitado aparece, como em 
um fragmento de Anaxímenes em que o ar é a origem da natureza, e ilimitado (DK 13 A 5). Filolau, no entanto, não aceita relacionar o ilimitado com qualquer elemento ou identificá-lo com o princípio do

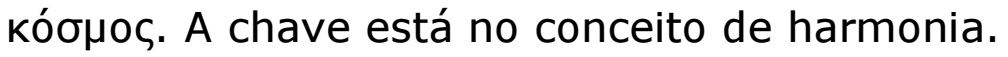

No fragmento seguinte, Filolau explicita o papel da harmonia no encaixe entre ilimitado e limitado: "Visto que esses dois princípios (limitado e ilimitado) não são iguais, nem de iguais famílias, já seria

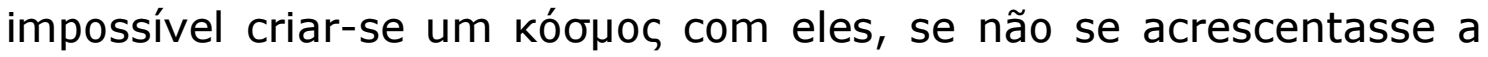
harmonia, de qualquer maneira que ela tenha vindo a ser. As coisas iguais e de iguais famílias em nada precisam, pois, de harmonia; mas as desiguais (como os dois princípios) não de famílias iguais e não igualmente dispostas, são necessariamente fechadas em tal harmonia que se destina a conter-se em uma ordem" (DK 44 B 6).

O tratado de Filolau foi bastante respeitado em seu tempo e foi lido, ao que parece com muito cuidado, por Platão. No diálogo Filebo, Platão adapta a cosmologia de Filolau a seus propósitos, desenvolvendo a ideia dos dois princípios - limitado e ilimitado - no âmbito da alma humana. Sócrates, Filebo e Protarcus discutem qual é

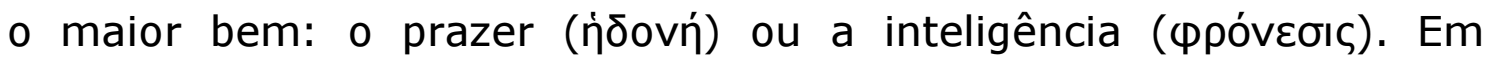
defesa da segunda, Sócrates argumenta que o prazer, e seu oposto, a dor, por possuírem graus de intensidade, pertencem à classe do ilimitado. Já a sabedoria, que traz implícita a ideia de número e medida, ao limitado. E, em uma ressonância pitagórica, Sócrates dá um exemplo de limitado e ilimitado na música. O som é uma coisa só, e ilimitado, pois admite gradações: é possível perceber se um som é grave, agudo ou intermediário. No entanto, isso não torna ninguém músico; apenas "quando tiveres alcançado o número e a qualidade dos intervalos da voz com relação ao tom agudo e grave, e os limites dos intervalos e todas as combinações (биотńнata) derivadas deles, as harmonias, e ainda os efeitos correspondentes nos movimentos do corpo (...) medidos pelo número, chamados de ritmos e medidas (...) 
terás te tornado músico" (Filebo, 17 b-e). Ou seja, quando o som é (de)limitado pelo número, torna-se tom musical. Argumento semelhante encontramos no Fedro, como apontamos no início deste capítulo (p.32).

\section{A fixação das consonâncias}

A harmonia "fechada em uma ordem" é descrita no segundo parágrafo do fragmento acima referido, tal como disposto na edição Diels-Kranz, ${ }^{18}$ e a sua tradução apresenta algumas peculiaridades importantes. Em geral, o início costuma ser traduzido assim: "A harmonia abrange uma quarta e uma quinta; a quinta é maior que a quarta por um tom" (DK 44 B 6). Poderíamos fazer uma tradução mais literal do texto: "O tamanho ( $\mu \varepsilon \dot{\varepsilon} \varepsilon \theta 0 \varsigma$ ) da harmonia é quarta e quinta", mas ainda assim estaríamos longe do seu significado preciso. A harmonia, aqui, refere-se à oitava. Filolau utiliza o termo harmonia

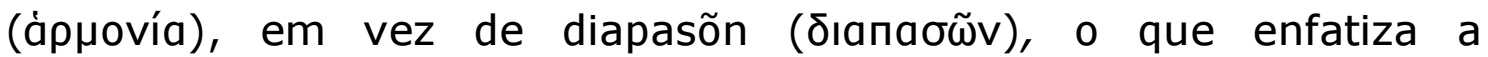
coerência e unidade do sistema. Além disso, não aparecem os termos

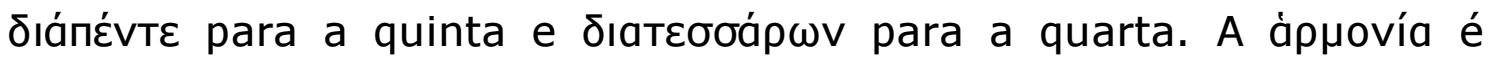

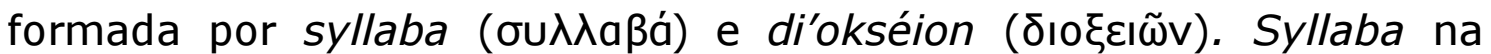
linguagem corrente musical antiga equivalia ao intervalo de quarta,

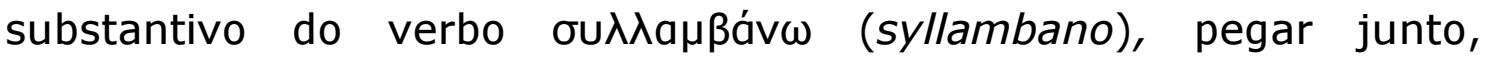
reunir $^{19}$. Esse termo refere-se a algo bem concreto: as cordas abaixo dos dedos do músico em uma posição inicial na lira ou na cítara, e

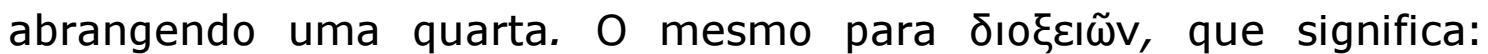
através das cordas mais agudas e seriam as cordas restantes, mais

\footnotetext{
${ }^{18}$ Existem dúvidas filológicas a respeito da reunião dos dois parágrafos.

$19 \mathrm{Em}$ português a sílaba, em geral, é a reunião de uma consoante e uma vocal. Eram comuns, no período clássico grego, as analogias entre a linguagem verbal e a musical; no Filebo, o personagem Protarcus diz que compreendeu melhor o argumento socrático, que se havia utilizado da música para desenvolvê-lo, quando isso é feito tomando por base o alfabeto.
} 


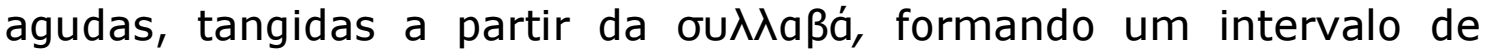
quinta.

Andrew Barker fez um estudo detalhado desse parágrafo do fragmento e suas conclusões são oportunas para o desenvolvimento das questões suscitadas no decorrer deste trabalho. De acordo com Barker, essas expressões no texto de Filolau "parecem vir da linguagem dos músicos, em vez dos filósofos e cientistas, e harmonia habita ambas as esferas". Ou seja, a linguagem nesse trecho não envolveria cálculos matemáticos, fazendo uma "referência direta aos componentes da afinação que se apóiam em posições específicas, e não a tamanhos de intervalos que independem das suas posições das cordas no instrumento" (2007, p.275-8).

A afirmação é adequada no que diz respeito à primeira oração do fragmento de Filolau, contudo, na segunda: "a quinta é maior que a quarta por um tom", o termo grego utilizado para tom não é Tóvo

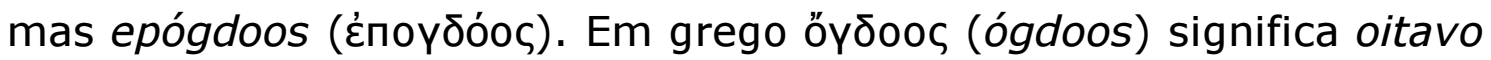
e epógdoos é o que contém um inteiro mais um oitavo, ou seja, a razão 9:8. A razão do tom também foi apresentada pelos pitagóricos, apesar de fugir do esquema dos quatro primeiros números inteiros e por isso o intervalo não era elencado entre as consonâncias. A menção a essa localização do epógdoon retorna adiante no fragmento com um significado ligeiramente diferente.

Para compreender a escala de Filolau, é preciso saber que, nesse sistema, as consonâncias são nitidamente distintas dos outros sons do tetracorde, com exceção do tom inteiro. De acordo com Cleônides, teórico provavelmente do século II d.C., "os intervalos

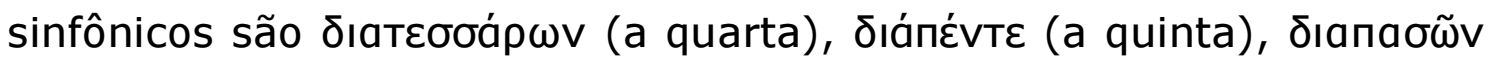
(a oitava) e os assemelhados (os compostos: quinta ou quarta mais uma oitava e oitava dupla). Os intervalos diafônicos são todos

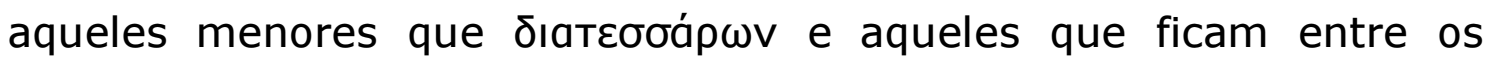
intervalos sinfônicos" (Apud Grande, 1960, p.403). Esses últimos, 
para os pitagóricos, pertenceriam à classe do áncípov (apeíron), do ilimitado (ou indefinido). As quatro notas do tetracorde dividiam-se em fixas e móveis. As consonâncias eram formadas pelas fixas (ou fixadas por elas). Como comentou Paul Tannery: "ele (Pitágoras) se satisfez em determinar os sons fixos (do sistema musical grego); e deixou de lado, na classe do indefinido (áncípov), a múltipla variedade dos sons móveis" (1912, p. 80).

Assim, Filolau inicia a construção da escala pelas consonâncias (notas fixas): "Da únátns subindo até a $\mu$ éon, temos uma quarta, da

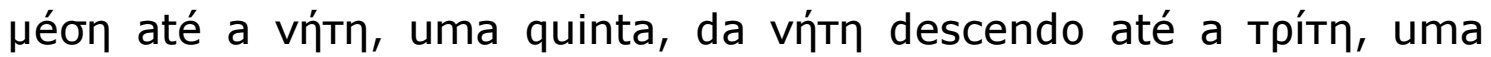
quarta, da трі́тп até únáтns, uma quinta." (DK, 44 B 6). Aqui, o mais importante não é o nome das notas e a sua posição, mas o fato de Filolau descrever os sons fixos consonantes da escala. A ênfase está na demonstração de que os intervalos consonantes podem ser formados com qualquer combinação de notas, ou seja, os intervalos são elementos autônomos. A escala pode ser ascendente ou descendente, não importa, o modelo é coeso, harmônico, pois as quartas e quintas entrelaçam ("fecham") a oitava. E suporta

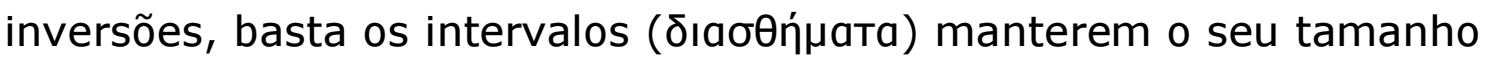
( $\mu \varepsilon ́ \gamma \varepsilon \theta \circ \varsigma)$.

Como mostrou Winnington-Ingram, nem todas as escalas antigas abrangiam uma oitava, existiram muitas formações de escalas. Para ele, o "sentimento da oitava não é um desenvolvimento primitivo da consciência" (1968, p. 23). Se for assim, só a partir de um determinado momento a oitava começou a ser percebida como uma consonância importante e, mais do que isso, como um intervalo musical. E o mesmo deve ter ocorrido com os intervalos de quarta e quinta. O fato é que só após terem sido percebidos como tais poderia ocorrer o salto fundamental: a sua tradução em razões numéricas.

Mas, no momento em que Filolau escreve, já havia essa consciência, portanto, o texto não exporia nada de novo. Porque é 
perfeitamente possível saber de maneira empírica que a oitava é a reunião da quarta e da quinta e que a quinta é maior que a quarta. 0 autor parece falar em uma linguagem intermediária, preparando 0 discurso para introduzir as razões numéricas, que talvez ainda fossem

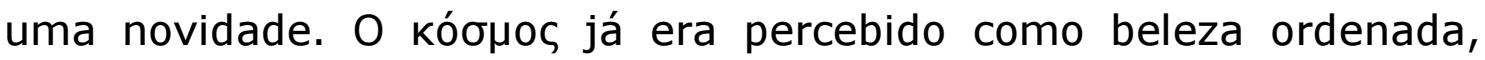
essa ideia estava colocada. O assunto agora era da maior importância: as razões musicais confirmariam a lei da harmonia como raiz fundante da natureza. De acordo com a concepção pitagórica, tudo que existe poderia ser expresso por um número, mas a música revelava que as coisas eram, elas mesmas, invisível e intimamente, números. O número seria de fato o elo entre todas as coisas, revelador dos princípios de analogia e semelhança.

E partindo desse ponto, acessível a qualquer cidadão grego com sua respectiva educação musical, Filolau avança firme no terreno

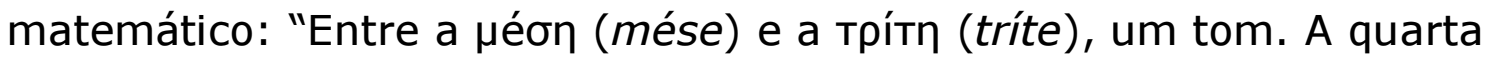

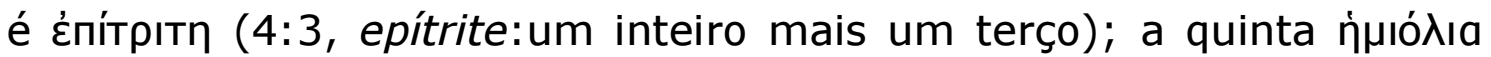
(3:2,hemiólia:um inteiro mais meio) e a oitava é dupla (2:1)" (DK 44, B 6). Como no início, o termo grego utilizado para tom não é Tóvos (a diferença de tensão da corda entre os intervalos de quarta e quinta), mas epógdoos, que refere-se à razão 9:8.

É importante fazer um parêntese para ressaltar a observação de Szabó de que Filolau ao dizer que a diferença entre 3:2 e 4:3 é igual a 9:8, está fazendo alusão a operações efetuadas no cânone, pois matematicamente não é a subtração que resulta 9:8, mas a divisão de 4:3 e 3:2 (2000, p.114-5) ${ }^{20}$. De acordo com o autor romeno, no cânone seria possível examinar o intervalo como uma

20 Cânone é o instrumento que teria sido criado pelos pitagóricos para as demonstrações visuais das razões numéricas. Diferente de Szabó, autores como Flora Levin consideram que o cânone seria uma invenção posterior visto que nem Platão nem Aristóteles falam dele. Consideramos aqui a hipótese de Szabó, pois, dados nossos insuficientes conhecimentos de matemática, pareceu-nos a única explicação para as inversões entre subtração e divisão e adição e multiplicação, que ocorrem também no Manual de harmônica de Nicômaco de Gerasa. Para uma explicação detalhada, ver Szabó, 2000, p. 114-5. 
diferença, o mesmo acontecendo com a inversão entre adição e multiplicação: "da mesma maneira, é devido à referência a uma operação efetuada no cânone que se explicam as expressões da música teórica que exprimem a multiplicação de duas razões como uma adição" (2000, p.132-3).

À parte a correção das sutilezas dos cálculos matemáticos, a construção diferente da frase que repete a razão do tom parece enfatizar agora a simetria do sistema, em que é necessário ter um ponto de equilíbrio, justamente o tom inserido "entre a mése e a tríte". O epógdoos agora não está sendo definido pela diferença entre a quinta e a quarta, mas é o núcleo da escala e ele é que a define.

Esses são os primórdios da teoria musical, tal como praticada nos círculos pitagóricos. Antes da sistematização pitagórica não há nenhuma evidência de uma base teórica para a afinação das escalas. Agora, o princípio passava a ser matemático, pois, citando novamente Szabó: "a empiria não apreende que a diferença entre a quinta e a quarta é 9:8 e que se deve atribuir à quarta uma razão 4:3 e, à quinta, a razão 3:2" (2000, p.133). Aos poucos não será mais necessário tocar, medir, ouvir, mas apenas calcular.

\section{A kómma pitagórica}

Filolau formula então o tamanho da oitava e da quarta: "assim a àpuovía abrange cinco tons e duas díesei , e a quarta, dois tons e

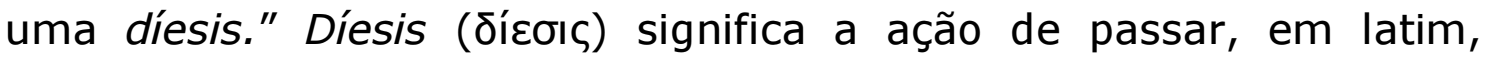
transitus. A díesis, na música grega, antiga era o intervalo mínimo de uma escala; no caso da escala diatônica pitagórica, que é a referência de Filolau, muito próximo do meio-tom. Só que não havia o meio-tom exato porque o tom não podia ser dividido ao meio, pois resultaria num número irracional. Isso era inconcebível para os pitagóricos, que consideravam a ausência de um número racional comprometedora da 
inteligibilidade de algo. Para contornar esse problema, serão feitos cálculos complicados, buscando acomodar a dificuldade e assim completar a escala musical.

Desse modo, o tom deveria ser dividido em duas díesei (expressa pela simpática razão de 256:243) e mais uma kómma (кó $\mu$ a:531441:524288!). Como podemos ver, relacionar alturas apenas a números racionais acaba por introduzir alguns problemas, fazendo despontar a fragilidade do sistema. Por exemplo, se tocarmos 12 intervalos de quintas na razão 3:2, em série, a última nota deverá ser $(3: 2)^{12}$; já ao tocarmos sete oitavas (que corresponderiam ao intervalo das 12 quintas) a última nota seria $(2: 1)^{7}$. As duas notas são quase a mesma, entre elas há uma diferença minúscula, que produz um intervalo dissonante, a coma pitagórica.

Essa dificuldade só será solucionada mais tarde com a divisão da escala em meios-tons, o temperamento igual, baseado nos números irracionais. Mas como observa Abdounour: "o experimento de Pitágoras contribui com a ideia de temperamento na medida em que propicia a construção de uma escala que não se "fecha" resultando na coma pitagórica. As diversas tentativas de distribuir tal diferença culminam com a repartição logaritmicamente equivalente, correspondente ao temperamento igual" (1999, p. 201).

O que importa agora é considerar o significado como um todo desse sistema inicial. A música começava a descolar-se da sua origem em tetracordes e essa nova estrutura matemática se tornará a base da música ocidental dos próximos dois mil anos, até ser substituída pelo sistema temperado moderno, que, no entanto, manterá nas relações sistêmicas da harmonia aspectos da estrutura matemática. A gama diatônica, tão apreciada pelos pitagóricos por sua simetria, irá tornar-se, gradativamente e com variações de afinação, a escala de referência da música ocidental. 
O destaque aos intervalos de quintas é um prenúncio do ciclo da quintas do sistema tonal, quando a quarta será tratada como dissonância, ou semi-dissonância. Além disso, é importante o fato de a oitava ser "encaixada" pelas quartas e quintas tanto de cima para baixo quanto de maneira inversa. Essa concepção da organização escalar como modelo matemático ressoará no século XVIII na teoria da inversão dos acordes de Jean-Philippe Rameau (1682-1764).

\section{A cosmologia pitagórica}

O livro de Filolau é o testemunho do nascimento da ciência harmônica que, buscando padrões numéricos simples de articulação entre o visível e o invisível (por exemplo, corda/som), reduzia a multiplicidade à unidade, dando inteligibilidade à natureza: "sem ele (o número) todas as coisas são ilimitadas, obscuras e imperceptíveis" (DK44, B11). Em vez de buscar uma substância primordial, como outros pensadores da época, os pitagóricos encontraram um princípio imaterial com forte potencial de organização hierárquica. Nas palavras de Aristóteles: "como vissem nos números as modificações e as proporções da harmonia e, enfim, como todas as outras coisas Ihes parecessem, na natureza inteira, formadas à semelhança dos números, e os números as realidades primordiais do universo, pensaram eles que os elementos dos números fossem também os elementos de todos os seres, e que o céu inteiro fosse harmonia e número"21.

Diz Filolau: "tudo que é possível de ser conhecido tem um número", ou seja, a inteligibilidade das coisas é dada pelo número. E ainda: "pode-se ver a natureza do número e sua potência em atividade, não só nas (coisas) sobrenaturais e divinas, mas ainda em

${ }^{21}$ Metafísica, I, Cap. V. Trad. de Vinzenzo Cocco. Coleção "Os Pensadores". São Paulo, Abril, Cultural, 1979, p. 21. 
todos os atos e palavras humanos, em qualquer parte, em todas as produções técnicas e na música" (DK44, B11). As especulações musicais estavam inseridas no contexto de uma cosmologia, que era na verdade uma filosofia que, por sua vez, fazia a conexão entre as diversas áreas do conhecimento, da astronomia à medicina.

A teoria astronômica pitagórica tem o seu lugar na história da astronomia como um todo. Os pitagóricos teriam sido os primeiros a sustentar a ideia de que a Terra e o universo tinham a forma esférica (Cf. Heath, 1981). ${ }^{22}$ É difícil verificar como eles teriam chegado a essa conclusão, talvez pela observação dos eclipses. Contudo, considerando o caráter essencialmente matemático de sua filosofia da natureza, é possível que a suposição fosse "puramente matemática", como diz Heath, "ou estético-matemática; ou seja, Pitágoras atribuiu a forma esférica à Terra (assim como ao universo) pela simples razão de que a esfera é a mais bela das figuras sólidas" (1981, p.162-3).

O pitagorismo desenvolveu uma cosmologia não-geocêntrica e, na Renascença, Copérnico fez referência aos pitagóricos ao defender o heliocentrismo. Filolau, em seu livro, diz que a Terra e os sete planetas, o que incluía a Lua e o Sol, giravam em torno de um fogo central. Haveria ainda uma contraterra, colinear à Terra, perfazendo o número dez (Filolau, DK44, B17). Para Aristóteles, a inclusão dessa contraterra destinava-se a perfazer o número 10 , ou seja, por um

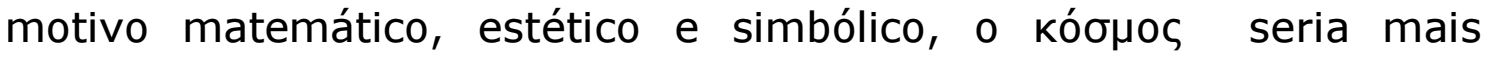
perfeito assim.

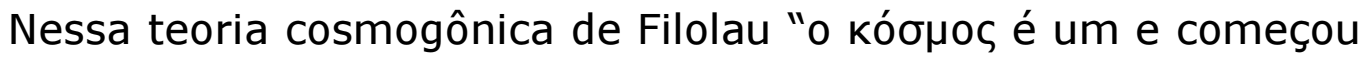
a vir a ser a partir do centro, e do centro para cima, nos mesmos intervalos (ঠıабөńната) que os de baixo" (Filolau, DK44, B17). Os corpos celestes são esferas e movem-se em círculos, um espaço

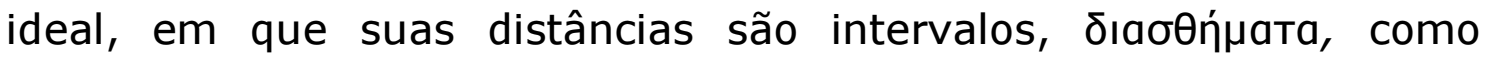

${ }^{22}$ Contudo, de acordo com Boyer (1999, p. 38), existem contestações acerca dessa tradição, que atribui o conceito de terra esférica aos pitagóricos. 
vimos, termo também utilizado para os intervalos musicais. Tal como a escala musical, a teoria astronômica é perfeitamente simétrica.

Para Heath, a astronomia pitagórica "é pura matemática, combinada com aritmética e harmonia. A descoberta capital de Pitágoras da dependência dos intervalos musicais das proporções numéricas levou seus sucessores à doutrina da "harmonia das esferas" (1981, p. 165).

As teorias acústicas que relacionavam a velocidade com a característica do som estendiam-se ao movimento dos planetas: os mais velozes produziriam sons mais agudos que os mais lentos. E as distâncias entre eles corresponderiam às razões numéricas musicais. Apesar de combatida por Aristóteles ${ }^{23}$, detalhes dessa cosmologia são descritos por seu comentador Alexandre de Afrodísias, do século III d.C., conhecido como o último comentador peripatético, "esse som que eles (os planetas) produzem durante seu movimento é profundo no caso dos mais lentos e alto no caso dos mais rápidos; esses sons então, dependendo da razão das distâncias, soam de modo que seu efeito combinado é harmonioso" (Apud Hunt, 1978, p.12).

Esse mito é relatado na República de Platão como o mito de $\mathrm{Er}$, o soldado armênio que narra uma cosmologia fantástica que ficou conhecida como o mito da harmonia das esferas (614b-617d). No Timeu (35b-36c), a escala musical pitagórica é descrita como um princípio cosmogônico e relaciona-se à escala de Filolau no que diz

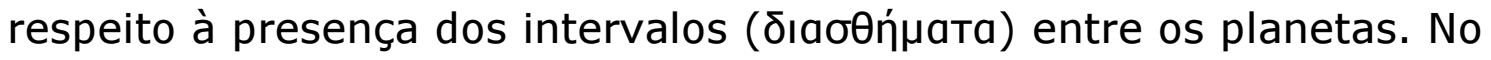

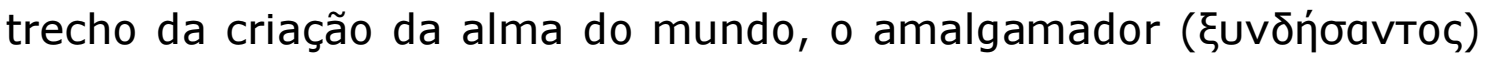
cria o universo corpóreo - visível e tangível conjugando-o por um elo,

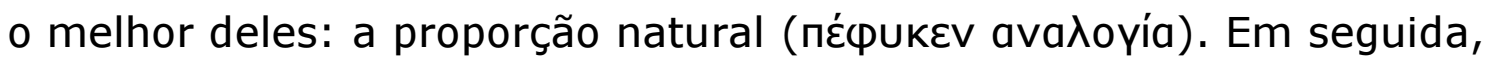

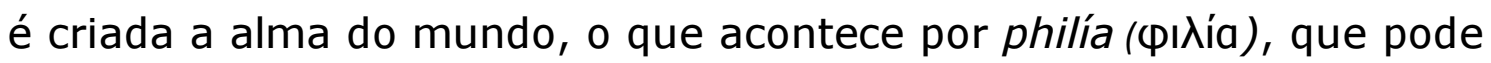
ser traduzida por amor. Essa criação acontece com o entrelaçamento de números duplos e triplos, quadrados e cúbicos caracterizando uma

\footnotetext{
${ }^{23}$ Posição esta explicitada, por exemplo, em De Caelo, Livro II, 9, 16-32.
} 
criação musical, harmônica. Depois, o amalgamador preenche os

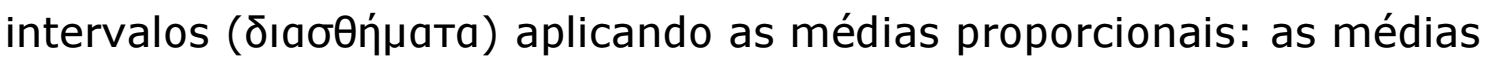
harmônicas geram intervalos de quartas e aritméticas, os intervalos de quintas. Por fim, completa os intervalos de 4:3 com os intervalos de 9:8 deixando uma parte de cada um deles. O tom será dividido em dois intervalos desiguais, duas diései de tamanhos diferentes, chamados leímma ( $\lambda \varepsilon \tilde{\mu} \mu \mathrm{a})$ (243:256), a razão que está em Filolau, e apotomé (áпотонń) (2187:2048) (Timeu, 31b-36b). A escala avança de maneira ortodoxa por quatro oitavas, muito além do acessível à voz humana e os números surpreendentemente correspondem à posição dos primeiros harmônicos, sons constitutivos das notas que só serão comprovados experimentalmente no século XVII.

A cosmologia pitagórica está presente também na medicina da época. É bem provável que Filolau conhecesse a obra do médico, também de Crotona, Alcméon (c. 560-500 a.C.), que teria sido contemporâneo do próprio Pitágoras. Foi ele quem elaborou a teoria da desarmonia como causa das enfermidades e pode ter sido um pioneiro da embriologia (Huffman, 2005). Barker chama a atenção para uma passagem no tratado médico hipocrático De victu, em que o autor discute o desenvolvimento do feto humano: "quando movimenta-se para um lugar diferente, alcança-se a àpuovía correta contendo as três consonâncias: syllaba ( $\sigma u \lambda \lambda a ß a ́)$, di'okséian

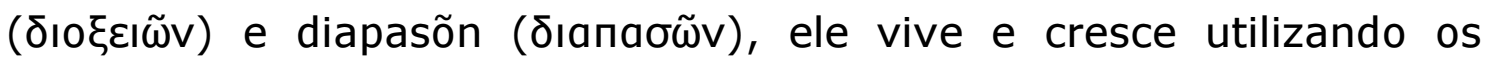
mesmos nutrientes que antes. Mas se ele não alcançar a àpuovía e os elementos graves não foram consonantes com os agudos, na primeira consonância, na segunda, ou naquela que passa por tudo diapasõn, ou seja, a oitava, se uma delas estiver faltando, toda a afinação (Tóvos) é inútil" (Apud Barker, 2000, p.280). É surpreendente a semelhança do texto médico com a escala de Filolau, o que reafirma o caráter organicista da cosmologia pré-socrática e pitagórica. Como observou Max Weber: "o fenômeno da mensurabilidade dos intervalos 
"justos" [leia-se consonantes] foi, uma vez reconhecido, de extraordinária impressão sobre a imaginação, como demonstra a imensa mística dos números ligada a isto" (1995, p. 85).

\section{Os desdobramentos da harmônica: Arquitas}

Arquitas de Tarento viveu na primeira metade do século IV a.C e foi contemporâneo de Platão. Além de matemático e filósofo, Arquitas foi também um aclamado líder político e, segundo contam, prestava atenção especial às crianças, pois teria sido o inventor de um pequeno chocalho para acalmá-las. No ano de 361 a.C., Arquitas foi o responsável pelo envio de um navio para resgatar Platão das mãos do tirano de Siracusa, Dionísio II. Segundo alguns estudiosos, a Sétima carta de Platão, em que ele narra a experiência em Siracusa, seria endereçada ao próprio Arquitas (338a-339d). Apesar disso, os dois tinham desentendimentos em questões matemáticas, filosóficas e políticas.

Arquitas esteve envolvido em vários ramos da atividade científica, todos eles interligados pelas propriedades do número. Ele radicalizou o pensamento analógico pitagórico, estendendo-o às téknai como a mecânica. Dedicou-se intensamente à música, avançando nas questões de afinação da lira e sofisticando os cálculos das razões numéricas e das médias proporcionais. De certa forma, ele aproximou a harmônica do fenômeno da experiência musical. Ao mesmo tempo em que avançou no campo da física acústica, Arquitas introduziu mais rigor ao cálculo das razões numéricas musicais e propôs novas afinações da escala, calculadas por meio das chamadas médias proporcionais.

Na harmônica pitagórica não é possível dividir os intervalos básicos na metade. Portanto, a oitava não pode ser dividida em duas partes iguais, deve ser dividida em uma quarta e uma quinta. Em 
linguagem tonal moderna, podemos exemplificar isso dizendo que a oitava não poderia ser dividida por seu trítono (aliás, a grande dissonância, responsável pelo desenvolvimento da tonalidade), assim como o tom. Por outro lado, é possível dividir a dupla oitava na metade. Baseando-se nessas duas propriedades, Arquitas produziu uma rigorosa prova para as razões epimóricas ou superparticulares $(2: 1,4: 3,3: 2$ e 9:8), razões do tipo $n+1: n>1$, dizendo que elas não poderiam ser divididas em duas partes iguais. Essa afirmação será apresentada ligeiramente modificada no início do século III a.C. na famosa e problemática Proposição 3 da obra Divisão do cânone, que abordaremos adiante.

\section{As médias proporcionais}

O sistema cosmológico pitagórico de encaixes articulados harmonicamente tinha sua expressão matemática nas médias proporcionais que, no âmbito da teoria das proporções, "promoviam a união entre as disciplinas matemáticas" (Szabó, 1977, p.107).

A teoria das proporções - relação entre duas razões desempenhou papel crucial na epistemologia pitagórica e, de acordo com Heath, foi desenvolvida "muito cedo na sua escola com referência à teoria da música e aritmética" (1981, p. 85). Dizem que foi entre os babilônios que Pitágoras teria conhecido as médias aritmética, geométrica e subcontrária, a qual Arquitas mais tarde renomearia para harmônica, e ainda, a proporção áurea.

Uma média proporcional é uma relação matemática constante que cria uma analogia entre dois termos, através de um terceiro. Os pitagóricos generalizaram 0 conceito de média proporcional e chegaram ao número de dez médias proporcionais. Coincidentemente ou não, duas delas, quando aplicadas ao comprimento de uma corda, geram duas das consonâncias perfeitas: a quarta e a quinta. A razão 
4:3, o intervalo de quarta, é obtida pela média harmônica da divisão da oitava (2:1). O intervalo de quinta (3:2) é a sua média aritmética.

Como esclarece Barker: "quando a oitava é dividida no modo familiar de duas quartas separadas por um tom, a estrutura é demarcada em quatro notas, das quais a segunda está para a primeira na razão 4:3. A terceira nota está para a segunda na razão 9:8. E a última nota está para a terceira na razão 4:3. Portanto, a razão da terceira nota para a primeira e da última para a segunda é de 3:2 e a razão da última para a primeira, 2:1. Os menores números inteiros que captam esse arranjo são 6, 8, 9 e 12" (2000, p. 302). A média aritmética dos quatro números é $9(9: 6=12: 9)$ e a média harmônica, 8 (12:8 = um terço de 12 e 8:6 = um terço de 6 ).

Luigi Borzacchini (2007, p.278) defende que a logística de Arquitas, que ele proclamava como sendo o núcleo das matemáticas, não era uma arte prática do cálculo, como querem alguns, mas a ciência das relações entre os números, no sentido dado por Tannery: "é uma característica da tradição pitagórica que ela apreende os números em si no mundo visível, mas suas razões no mundo audível" (2002, p. 70).

O segundo fragmento de Arquitas relaciona três médias, como pertencentes à música: "a música tem três médias, uma é a aritmética, a segunda é a geométrica e a terceira é a contraposta que chamamos de harmônica" (DK 47 B 2). E segue formulando cada uma delas. As médias aritmética e harmônica estão relacionadas à divisão da oitava respectivamente nos intervalos de quinta e quarta ${ }^{24}$.

Convém lembrar que as afinações utilizadas na música grega no tempo de Arquitas e Platão eram bastante sofisticadas e as razões numéricas de Filolau não davam conta da música real praticada. Além de formalizar a questão das médias proporcionais, Arquitas introduziu

24 A média aritmética é expressa pela fórmula $b=a+c / 2$, a média harmônica $b=2 a c / a+c$ e a média geométrica $b^{2}=a \cdot b$ 
essas mesmas médias entre as quartas e as quintas, o que, por analogia, deveria produzir consonâncias menores.

O procedimento aproximou a escala de novas ressonâncias presentes na série harmônica musical. Como diz Abdounour, "o intervalo de terça maior obtido por Arquitas concorda com aquele presente na série harmônica. Tal fenômeno levar-nos-ia a imaginar que Arquitas possuísse um ouvido sensível ao perceber que a terça correspondente a 4:5, mais baixa que a pitagórica, soava mais natural, uma vez que se fundia exatamente dentro dos harmônicos naturais de uma nota. Enquanto Pitágoras calcula frações subjacentes à escala utilizando apenas percursos de quintas, Arquitas considera fortemente cálculos de médias aritméticas e harmônicas na geração de seu sistema musical" (1999, p. 17).

O matemático e filósofo foi ainda ao interior do tetracorde para calcular as suas divisões nas três espécies ou gêneros: diatônico, cromático e enarmônico. Ele buscou descrever matematicamente as escalas então em uso, a partir da observação da forma como os músicos afinavam os instrumentos, distanciando-se da escala diatônica pitagórica simplesmente porque ela não era utilizada, ao menos em sua época. A escala de Filolau era constituída das razões 9:8 / 9:8 / 256:243 (três intervalos formando uma quarta) e 9:8 / 9:8 / 9:8 / 256:243 (quatro intervalos formando uma quinta) e abrangendo a tessitura de uma oitava. A estrutura de Arquitas mantém-se coesa com o fulcro do epógdoos em seu centro, mas os intervalos são bem mais complexos ${ }^{25}$.

Esses novos cálculos dos intervalos foram talvez um motivo de desentendimento com Platão, para quem mudar uma escala faria

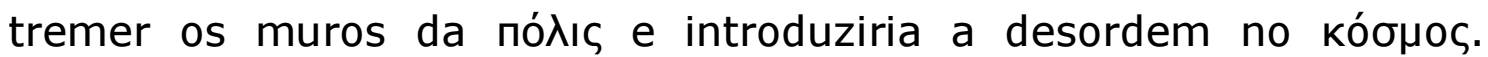
Lembremos que, para a filosofia platônica, as relações harmônicas

${ }^{25}$ Para o gênero enarmônico: 5:4 / 36:55 / 28:27 / 9:8 / 5:4 / 36:55 / 28:27. Para o gênero cromático: 32:27/ 243:224 / 28:27 / 9:8 / 32:27 / 243:224 / 28:27. Para o diatônico: 9:8 / 8:7 / 28:27 / 9:8 / 9:8 / 8:7 / 28:27. 
estavam presentes na geometria, na estereometria, através da analogia entre a superfície e o volume (Epinomís, 990c-991a) e na astronomia (Timeu $47 \mathrm{a}-\mathrm{b}$ ), nos movimentos das órbitas dos astros.

Segundo Barker (2007, p.307), talvez tenha sido endereçado a Arquitas o comentário sarcástico de Platão que aparece no diálogo entre Sócrates e Glauco na República: "O comportamento deles é ridículo (...) esticando os ouvidos como que para ouvir a conversa dos vizinhos, alguns deles dizendo que conseguem ouvir um som entre dois, (...) colocando os ouvidos antes da mente (voũc). Você está falando - eu disse - daquelas pessoas que torturam as cordas do instrumento esticando-as com as cravelhas para interrogá-las $(\ldots)^{\prime 26}$.

Como já vimos, em Platão, a ciência do número distancia-se da técnica e da arte. No diálogo Epinomís, o personagem estrangeiro de Atenas, após pedir perdão aos predecessores, faz uma extensa relação das ciências que não levam à virtude e à sabedoria. No catálogo, estão listadas a fabricação de farinhas e fermento e sua transformação em alimento, a agricultura, a construção, a marcenaria, a serralheria e a fabricação de ferramentas até a caça, a medicina, o teatro, a pintura, a prática musical e a adivinhação, "trabalhos úteis para a sociedade, mas que não entram em consideração quando se trata da virtude (ápetń)" (Epinomís, 975 a976c).

\section{A média geométrica e os incomensuráveis}

As fórmulas de Arquitas para as médias proporcionais mencionam, além das médias aritmética e harmônica, a geométrica. Contudo, não haveria lugar para a média geométrica na divisão da oitava, já que ela não poderia ser dividida em dois subintervalos por

\footnotetext{
${ }^{26}$ Trecho completo na República de Platão, 531a-531c.
} 
um número inteiro. A questão não se resume ao cálculo. Musicalmente, a divisão geométrica da oitava dá o intervalo de uma quarta aumentada ou uma quinta diminuta, o chamado trítono, distância de três tons considerada extremamente dissonante. No contraponto medieval, o trítono levará o sugestivo nome de diabolus, por dividir a oitava em duas partes. Essa divisão, no entanto, será o motor da música tonal, que se fixará a partir do século XVII, pois é uma cisão energética, conduzindo a oitava a duas direções diferentes. Contudo, se mais tarde o intervalo foi considerado precioso exatamente por seu caráter dissonante, não era o caso da música antiga grega. Isso nos leva a considerar as conexões entre a teoria musical das proporções e a descoberta da incomensurabilidade ou, no plano das disciplinas matemáticas, entre música e geometria.

Não se sabe ao certo quando e como aconteceu a descoberta da incomensurabilidade ou ainda a constatação de que os números inteiros e suas razões eram insuficientes para descrever propriedades muito simples da geometria, tais como a relação entre o lado e a diagonal de um quadrado. No final do século XIX, Paul Tannery investigou o papel da música grega no desenvolvimento da matemática pura. De acordo ele, em suas Mémoires scientifiques, a harmônica, assim como as outras três ciências matemáticas, havia sido contemplada nos Livros 5 e 6 dos Elementos de Euclides. A ciência musical estaria na teoria das proporções (Livro 5) e na aplicação dessa teoria (Livro 6). Contudo, as razões entre números inteiros a propósito dos intervalos musicais teriam sido elaboradas nos escritos matemáticos anteriores a Eudoxo de Cnido, a quem são atribuídas as teorias presentes nos dois livros. Eudoxo desenvolveu uma teoria das proporções aplicável também às magnitudes incomensuráveis, correlacionando segmentos de reta sem a utilização de números. Tannery inclusive sugeriu ter sido Eudoxo o autor da 
obra Divisão do Cânone, recuando em uma geração a autoria ainda incerta do escrito.

Para Tannery, a origem da concepção grega de razão é essencialmente musical. A harmônica teria ainda exercido papel considerável na noção de incomensurável e na criação dos procedimentos de cálculo por aproximação de valor das raízes quadradas (1902, p. 68-69).

No final da década de 1970, Arpád Szabó também propôs que a teoria das proporções houvesse surgido na teoria musical pitagórica. Para ele, Arquitas fala em média geométrica no fragmento 2 porque ela teria nascido no contexto da música teórica, em princípio como um problema insolúvel, do ponto de vista da aritmética (2000, p.10511).

Para Szabó, a teoria harmônica seria, assim, um capítulo da teoria das proporções. Isso teria ocorrido pelo fato de os números serem representados por segmentos de retas, tal como na Divisão do

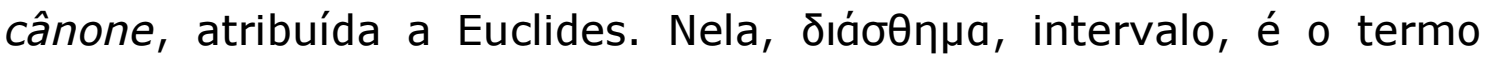
técnico para logos, razão. E, nos diagramas, cada intervalo é representado por dois segmentos de reta, buscando reproduzir a tradução das razões do monocórdio para um instrumento em que as notas eram produzidas por cada corda, como a lira, a cítara, o psaltério, ou seja, instrumentos multicordas ${ }^{27}$.

Outros autores reconhecem uma fase musical na descoberta da incomensurabilidade. Para Luigi Borzacchini, "a tradução do problema da música para a geometria foi feita no tempo de Arquitas, Eudoxo e Teeteto, e foi isso que deu um fundamento para o termo média geométrica, que não produzia consonâncias musicais, mas tinha instâncias geométricas fáceis e precisas" (2007, p. 297).

\footnotetext{
27 Existem controvérsias a respeito de quando os diagramas teriam sido incorporados à obra. Segundo Barbera provavelmente isso ocorreu na Bizâncio medieval. Haveria portanto uam versõa aritmética e outra geométrica da obra (Barbera, 1991, p.3).
} 
Arquitas foi professor de Eudoxo, que também manteve contatos com a Academia platônica. Para Borzacchini, no entanto, na Academia teria havido uma "desmusicalização" da teoria das proporções e, por isso, ela tornou-se conhecida como um problema apenas da geometria.

O autor italiano introduz a questão do par de opostos discreto/contínuo, ou adição infinita e divisão infinita. A música, que era considerada pelos primeiros pitagóricos uma ciência da quantidade discreta, do número, poderia ter sido estendida às quantidades contínuas. Para Borzachinni, "quando a teoria musical pavimentou a estrada em direção à incomensurabilidade, a ideia de continuidade geométrica era muito incipiente para desenvolver ou mesmo compreender tal descoberta. Talvez tenha sido exatamente a possibilidade do desenho geométrico de um intervalo musical não existente que promoveu o desenvolvimento da ideia aristotélica de continuidade" (2007, p. 293). Acreditamos que haja aqui um exagero do autor; contudo, é possível que a descoberta dos incomensuráveis tenha ocorrido no contexto de uma relação, ainda não elucidada, entre música e geometria.

No século XVII, no Prefácio do Livro III de Harmonia dos mundos, Kepler dá uma breve história da afinação musical. O astrônomo critica os pitagóricos por não terem percebido que os fundamentos das consonâncias deveriam ter sido investigados no âmbito da geometria e não da aritmética (Apud Walker, p.42-43). Para Kepler, como o som é um fenômeno contínuo e a harmonia dáse por meio do movimento, os termos das razões musicais são contínuos e não discretos. Suas causas devem ser buscadas nas figuras geométricas, o que ele fará.

Uma possibilidade para a presença da média geométrica no fragmento de Arquitas seria que ele estivesse pensando na divisão de duas oitavas ao meio, o que resultaria em uma oitava. Mas, será que 
Arquitas não buscaria uma resposta a partir da geometria? Se assim for, ele poderia estar fazendo referência a uma média proporcional que é própria da geometria, pois produz um número irracional, a proporção áurea. Ela foi definida por Euclides: "dividir em razão extrema e média uma reta finita dada" (Elementos, Livros II, 11 e VI, 30, apud Heath, 1981, p.304). Essa proporção correlaciona duas médias: "o primeiro de dois números está para a sua média aritmética, assim como a média harmônica está para o segundo número" (Boyer, 1999, p.38).

Para Boyer essa proporção poderia configurar-se como uma hipótese para a descoberta dos irracionais. O historiador da matemática mostra uma propriedade interessante dessa proporção áurea: ela se autopropaga, sendo o germe de um modo de crescimento logarítmico. Por exemplo, ela gera a duplicação infinita de pentágonos. Se traçarmos as cinco diagonais de um pentágono regular, as cinco linhas formam um pentágono menor, e isso pode ser feito indefinidamente (Boyer, 1999, p.35).

Como vimos, um dos problemas enfrentados pela afinação pitagórica dizia respeito à duplicação das quintas e oitavas que geravam ao fim um intervalo dissonante, a coma pitagórica. Arquitas, certamente, conhecia o papel da divisão áurea na duplicação dos lados do pentágono. Não teria ele pensado em aplicar, por analogia, esse modelo geométrico aos tons musicais?

De qualquer modo, a solução final para a falha da afinação pitagórica só viria com a descoberta dos logaritmos, que possibilitou a realização completa do temperamento. O procedimento foi criado pelo matemático escocês John Napier (1550-1617). Como chamou atenção Tannery, a etimologia do termo logaritmo é o "número da proporção", noção que não foi derivada das progressões de potências inteiras, mas sim da geometria (1902, p. 68-9). 
Arquitas buscou ouvir as ressonâncias dos instrumentos e, com um poderoso aparato de cálculo, aproximou-se dos números que as governam. Mas se a harmônica buscava a coerência racional das consonâncias, o fenômeno acústico pertence, antes de mais nada, ao reino da sensação e do infinito. 


\section{CAPÍTULO III}

\section{TEORIAS ACÚSTICAS DA ANTIGUIDADE}

\section{O experimento de Pitágoras}

A harmônica foi a responsável por conduzir as primeiras investigações acerca da natureza física e dos atributos do som, a partir da descoberta da proporcionalidade inversa entre a altura e o comprimento de uma corda, expressa pelas razões musicais. Autores da Antiguidade tardia buscarão inserir o feito em uma narrativa histórica, sendo a mais comum a lenda dos martelos. Ela foi narrada pela primeira vez no século IV a.C. por Xenócrates e reproduzida por Nicômaco de Gerasa em seu Manual de harmônica, escrito no século II d.C ${ }^{28}$.

Nicômaco conta que Pitágoras pensava como conseguir "algum tipo de ajuda instrumental para os ouvidos tal como a visão obtém da régua, do compasso e do transferidor e o tato, da balança e do sistema de pesos e medidas". ${ }^{29}$

Enquanto caminhava absorto nesses pensamentos, Pitágoras começou a ouvir sons que eram produzidos pelos golpes de quatro martelos em uma forja. Percebeu (com os ouvidos) que alguns eram belos, as consonâncias musicais de oitava, de quinta e de quarta. Ele pesou os martelos: um pesava 12 unidades, o outro 9, o terceiro 8 e o quarto, 6. Pitágoras associou os sons musicais consonantes à diferença de pesos entre os martelos. Os martelos com 12 e 6 quilos, quando golpeados juntos, produziam um intervalo musical de oitava, os martelos com peso 9 e 6, um intervalo de quinta e os martelos com peso 12 e 9, assim como os de 8 e 6 quilos, soavam um

${ }^{28}$ Boécio também narra a história em Institutione musica ii, 3, citado em Bower, 2002 , p.143.

${ }^{29}$ Nicômaco, Manual de harmônica, Cap. VI, p.83. 
intervalo de quarta. Como vimos, essa sequência de números estará sempre presente nos cálculos dos comentadores e refere-se às médias aritmética e harmônica, desenvolvidas pelos pitagóricos.

Pitagóras teria então combinado esses números nas razões 2:1 para a oitava, 3:2 para a quinta e 4:3 para a quarta. Em seguida, pendurou em um pedaço de madeira, por cordas de tamanhos iguais, pesos iguais aos dos martelos. Ao tangê-las, observou as mesmas relações intervalares: oitava, quinta e quarta. De acordo com o relato, Pitágoras não teria considerado nada além do peso na produção daquelas notas; nem a força, nem a bigorna, nem a forma dos martelos. Prosseguindo com o experimento, transferiu as mesmas razões para as tensões das cordas em um cavalete de um instrumento musical; testou-as também em instrumentos de sopro e percussão. Finalmente, chegou ao monocórdio ou cânone, um instrumento horizontal de cordas, no qual o filósofo pôde visualizar geometricamente as razões do comprimento das cordas, que concordavam com as consonâncias musicais ${ }^{30}$.

Subtraiu $4 / 3$ de $3 / 2$ (já vimos que não é a subtração) para achar a razão entre a quinta e a quarta, chegando à razão da dissonância: 9/8, o tom inteiro produzido pela diferença entre a quinta e a quarta. Estariam, assim, decifrados matematicamente os principais intervalos do antigo sistema musical grego.

O experimento não deve ter sido reproduzido por aqueles que narraram a história. Caso o fizessem, perceberiam que os fatores que determinam o tom musical do som de um martelo em uma bigorna são complexos e que a variação tonal é produzida pelo objeto percutido e não o contrário, que gera uma diferença pouco perceptível (Hunt, 1978). Além disso, as razões matemáticas não correspondem à relação entre a altura da nota e a quantidade de

${ }^{30}$ Em Nicômaco o nome pandoûra aparece associado a esse instrumento. Ver Nicômaco, Manual de harmônica, Cap. IV, p.61. 
tensão, mas esse ponto só será totalmente demonstrado no século XVII. Segundo Flora Levin, nos comentários à sua tradução do Manual de harmônica de Nicômaco, há indícios de que Claudio Ptolomeu tenha buscado fazer a experiência e percebido o erro, mas não chegou a desenvolver a questão (1994, p.93). Contudo, no caso do comprimento da corda, as proporções pitagóricas estão rigorosamente corretas. É possível que a popularidade do mito dos martelos tenha aumentado no momento em que se percebeu que outros fatores estavam em jogo na determinação das alturas, como pesos e tensões e, assim, buscou-se valorizar outras maneiras de dar veracidade à descoberta aritmética original.

Hipaso de Metaponte, contemporâneo de Pitágoras, teria feito experimentos com discos de bronze de mesmo diâmetro, cuja espessura estava na mesma relação das razões das consonâncias; percutindo os discos era possível ouvir as consonâncias. De acordo com Burkert: "a experiência é fisicamente correta, pois para discos que podem vibrar livremente, o número de vibrações é diretamente proporcional a sua espessura. Portanto, é possível confiar que Hipaso conhecia e tenha experimentado as razões numéricas das consonâncias" (Apud Szabó, 1977, p.122).

\section{Os primórdios da investigação do som}

Uma das primeiras referências à natureza propriamente física do som, independente das consonâncias musicais, está no Fragmento 1 de Arquitas, que fala do resultado do impacto do ar na produção do som: "é impossível haver som, se não houver um choque entre os corpos" (DK47, B1). A proposição está correta e era bem aceita no mundo grego. Mas Arquitas errará no diagnóstico dos sons graves e agudos. Segundo ele, se um bastão for vibrado rapidamente produzirá um som agudo devido à grande velocidade com que o som 
viaja pelo ar até nós. Quanto mais rápido, mais agudo e vice-versa. É evidente que há uma confusão entre a produção do som, que está até certo ponto correta, e a sua propagação. A altura não está relacionada à velocidade com que o som nos atinge. Contudo, podemos ver aqui um prenúncio da relação entre frequência de som e altura musical, que só será explicada em 1638 por Galileu.

De modo um pouco paradoxal, segundo um comentário de Porfírio, Arquitas pensava que as consonâncias seriam produzidas por dois ou mais sons percebidos como um único (apud Hunt, 1978, p.14). Se dois sons diferentes são percebidos como uma unidade, deveriam, de acordo com a tese anterior de Arquitas, nos atingir com a mesma velocidade, mas então deveriam ter a mesma altura e não seriam dois sons diferentes, logo, não poderiam gerar consonância, apenas igualdade. A confusão será percebida por Teofrasto de Eresus (372-288 a.C.), aluno de Aristóteles. Ele escreveu uma obra sobre música, que se perdeu, restando apenas citações também em Porfírio. Para Teofrasto, "a nota mais aguda não difere em velocidade da mais grave, pois senão não haveria consonância. Se há consonância, ambas as notas têm a mesma velocidade" (Apud Hunt, 1978, p.15).

O assunto da mescla de sons gerada pela consonância retornará em muitos autores e algumas vezes relacionado à concepção de harmonia da Antiguidade. Um trecho dos Problemas aristotélicos acrescenta um ponto de vista estético à questão: "Então nos comprazemos com a consonância porque é uma mistura de opostos que têm proporção uns com os outros. A proporção é um arranjo ordenado que é, por natureza, agradável."

Platão apresenta uma teoria acústica ao mesmo tempo física e geométrica (Timeu 80a-b). Ele descreve duas cordas que vibram, a seu ver, de modo circular, uma mais rapidamente que a outra. Elas têm uma amplitude desigual, mas coincidirão como dois redemoinhos 
que se adaptam um ao outro. A descrição é feita em detalhes, como resume Wersinger: "a consonância realiza-se desde que os dois redemoinhos adaptem-se um ao outro, como exprime com precisão o verbo пробáчavтєৎ (prosápsantes). Nesse sentido, é necessário que um dos anéis da primeira espiral coincida com um anel da segunda espiral para desenhar um círculo que coincida geometricamente com a consonância" (2001, p.54). A consonância será produzida ao final do movimento pelos dois sons que, separados no início, adaptam-se no tempo, até que o agudo e o grave estejam reunidos na impressão de um som único. Vemos que a preocupação aqui não é com a comensurabilidade, mas com uma simetria geométrica entre as duas espirais que irão produzir a consonância.

\section{A propagação do som e sua audição}

Havia duas posições divergentes quanto à teoria da propagação do som, questão especialmente importante para os gregos, amantes que eram dos grandes discursos e apresentações artísticas ao ar livre. Para os atomistas, o som possuía uma forma corpórea que imprimia o ar como pequenas partículas que viajavam da fonte geradora de som até o ouvido. Demócrito sustentava que "o ar é fragmentado em pedaços de formas similares e flui com os fragmentos de som" (Apud Hunt, 1978, p.24). Teofrasto atacou a concepção: "como alguns fragmentos de vento preencheriam por completo um teatro contendo dez mil homens? $"{ }^{31}$.

Para outra posição, não era o ar, mas seu movimento que produzia os sons e a transmissão se dava por meio de uma pulsação propagada em um meio elástico. A metáfora mais comum era a dos círculos concêntricos produzidos por uma pedra lançada na água.

31 Teofrasto citado por Porfírio no Comentário sobre a Harmônica de Ptolomeu (61.16-61.20), apud Barker, 1989, p.112-113. 
Nesse caso, o som seria propagado do mesmo modo que as ondas. Essa imagem estará presente em vários autores antigos como o filósofo estóico Chrysippus (c. 280-207 a.C.): "a audição ocorre quando o ar, que está entre aquilo que soa e o que recebe o som, é agitado, ondulando esfericamente e chegando aos ouvidos, como a água em um lago ondula em círculos, quando nela é jogada uma pedra" (Apud Hunt, 1978, p.24).

No século I a.C., o arquiteto e engenheiro romano Vitrúvio, em seu Tratado de arquitetura, utiliza a mesma imagem para falar da transmissão do som, no caso, da voz, pois está falando da importância da acústica na construção dos teatros: "Pois a voz é como um sopro flutuante do ar que se torna in actu sensível ao ouvido. Move-se através de infinitos círculos concêntricos, como se, lançada uma pedra na água imóvel, nascessem das ondas inumeráveis círculos aumentando a partir do centro, até ao máximo possível, e espalhando-se, a não ser que o impeça a estreiteza do lugar ou outro obstáculo que não deixe os traçados daquelas ondas encontrarem uma saída. E quando se Ihes interpõem dificuldades, as primeiras, voltando-se sobre si próprias, perturbam os traçados das que se Ihes seguem". Em seguida, o autor pondera que há, no entanto, uma pequena diferença, pois "se na água estes (os círculos) se movem planamente, a voz progride em amplitude e sobe gradualmente em altura (cap. V, p.182). O autor romano aconselha a escolher para a construção do teatro um local onde a voz "se transmita suavemente e não apresente repercussões". E faz uma classificação dos lugares de acordo com a transmissão da voz: dissonantes são os que impedem a sua transmissão, circunsoantes são aqueles em que a voz se perde, ressonantes são os que a ecoam e consonantes aqueles nos quais a voz é transmitida de maneira adequada permitindo a total inteligibilidade das palavras. 
Aristóteles havia sofisticado a questão distinguindo duas instâncias e incluindo a audição: "Existem dois tipos de som, um

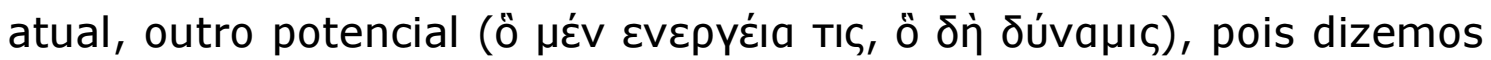
que algumas coisas não possuem som, como a esponja ou a lã, mas outras sim, como o bronze e todas as coisas que são sólidas e lisas, pois elas podem projetar o som. Ou seja, elas podem realmente produzir o som entre o objeto e o órgão da audição" (De anima (Tñৎ uUXñs) 419b, 5-9). No que diz respeito à anatomia e à fisiologia do ouvido, o conhecimento de Aristóteles era bastante avançado, como mostra a sua descrição no De anima (420 a, 13-16), na qual se percebe que o filósofo conhecia bem o labirinto e a cóclea.

Teofrasto compilou algumas teorias sobre o mecanismo da audição, entre elas a do médico Alcmeon de Crotona: "a audição é feita pelos ouvidos, porque dentro deles existe um espaço vazio, e esse espaço vazio ressoa". Essa seria também uma percepção présocrática, tal como encontramos no fragmento de Empédocles: "A audição ocorre pelo choque do ar contra a concha em caracol

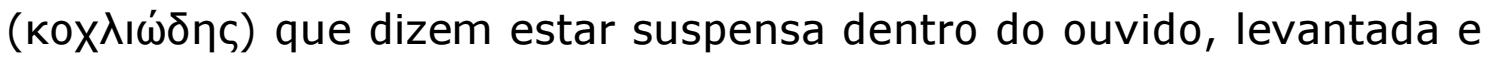
badalada como um sino" (citado por Teofrasto em Da Sensação, DK 31 A 86).

Para Aristóteles, "o órgão da audição é fisicamente unido ao ar, e porque está no ar, o ar de dentro é movido simultaneamente ao ar de fora" (420a). De acordo com Hunt, a afirmação de Aristóteles tem um interesse a mais "como uma sugestão antecipada da transmissão do som por conta da ação do ar no $\operatorname{ar}^{\prime \prime}(1978$, p. 21-3).

\section{Os avanços da escola peripatética}

A obra Problemas, à qual já nos referimos, é atribuída à escola peripatética e consiste de perguntas agrupadas em livros com suas respectivas respostas. Apesar de não ter autoria confirmada, muitas 
citações atribuem as questões ao próprio Aristóteles. No Livro XIX, encontramos perguntas sobre acústica, escalas, intervalos, afinação, percepção das consonâncias e dissonâncias e outros assuntos de importância para a ciência musical, assim como discussões sobre o papel da música na educação e na sociedade.

Em um dos problemas, o autor transpõe um princípio da ótica, que diz respeito aos ângulos de reflexão da luz, para o som: "Por que a corda grave encerra o som da aguda? Será porque a corda grave é maior? Ela, com efeito, compara-se a um ângulo obtuso, mas a aguda a um ângulo agudo" (XIX, 8, 918a 19-21). A partir dessa analogia geométrica, considera que o som mais grave contém o mais agudo, uma fina percepção do fenômeno da ressonância. Esse fenômeno foi o fundamento das razões numéricas de Pitágoras mas sua formulação na obra peripatética apresenta abordagens diferentes da pitagórica. Além da geométrica citada acima, outros problemas abordam a percepção e o ato concreto de tocar um instrumento. Por exemplo, no problema 24, o autor pergunta: "Por que, se alguém

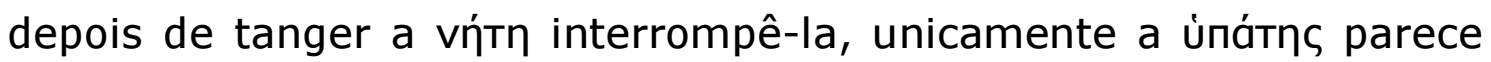
ressoar?" (XIX, 24, 918a, 37-40). E o autor questiona se isso acontece pelo fato delas gerarem um intervalo consonante, a oitava. O problema 12 também trata da questão: "Por que a mais grave de duas cordas sempre sustenta a melodia? Pois, se se omitir a

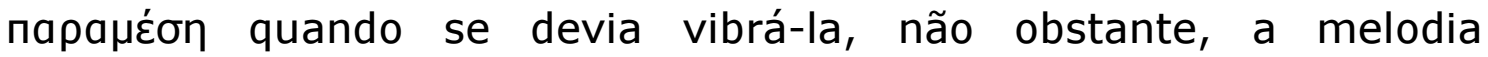
permanece; contudo, se se omitir a $\mu$ éon quando se deviam vibrar ambas, a melodia não se sustenta" (XIX, 24, 919b, 15-19). Como se vê, na obra aristotélica, há a contrapartida da observação à abordagem matemática.

O tratado De audibilibus, escrito provavelmente por volta do século III a.C, também é importante para o estudo das teorias acústicas antigas. De autoria incerta, a obra é considerada representante das ideias da escola peripatética, mas exposições 
sobre consonância ou altura musical estão completamente ausentes. Vamos encontrar nela discussões a respeito da produção e transmissão do som, da fisiologia da emissão vocal, das causas das várias modificações nas qualidades perceptíveis do som (distância ou proximidade, brilho, claridade, opacidade, aspereza). Há um grande interesse pela voz humana e analogias com os instrumentos musicais, tornando o De audibilibus uma fonte relevante de conhecimento dos antigos instrumentos musicais gregos.

No primeiro parágrafo da obra encontramos uma exposição física da produção e da propagação do som: "É um fato que todas as vozes e todos os sons surgem do choque entre os corpos ou do ar colidindo com eles; não é porque o ar toma uma forma como alguns pensam, mas porque ele se move da mesma maneira que os corpos: por contração, expansão e compressão, e como resultado dos impactos do ar ou das cordas musicais. Pois o ar ao ser movido, impinge sopros sucessivos ao ar próximo dele, forçando-o a moverse, de modo que o som viaja inalterado em qualidade até o limite da distância que alcança o movimento do ar. O distúrbio inicia sua força em um ponto e espalha-se por uma área mais ampla, como a brisa que sopra dos rios e das montanhas" (Apud Barker, 1989, p.99).

Um fragmento de Demócrito revela uma concepção semelhante: "uma vez que o movimento teve início, é enviado longe por causa da velocidade, pois o som surge com a condensação do ar" (Apud Hunt, 1978, p. 27). Hunt não deixa dúvidas sobre o alcance desses autores: "temos que considerar com humildade como notadamente pouca modernização da linguagem desses escritos antigos é necessária para qualificá-los a ainda servir como descrições elementares admiráveis do mecanismo físico de geração e propagação do som" (1978, p. 27-28). 


\section{As relações da acústica com a harmônica}

No mito dos martelos de Pitágoras o julgamento do ouvido é o primeiro critério para o estabelecimento das razões numéricas, visto que elas buscam revelar consonâncias e distingui-las das dissonâncias. Mas essa evidência dos sentidos será aos poucos descartada pela corrente pitagórica em favor de uma interpretação exclusivamente matemática.

Mas a questão das consonâncias e dissonâncias estava colocada em termos matemáticos e físicos: o que definia as razões simples e sua coordenação? Que tipo de interação física as constituía? O que estava em jogo, por exemplo, em uma relação de oitava? Havia a necessidade de uma complementação física que mediasse os conceitos matemáticos e a sua presença no mundo concreto.

$\mathrm{Na}$ Itália do século XVI essas questões retornariam para impulsionar a compreensão da reciprocidade entre a natureza do som e a música. Considera-se um marco desse recomeço duas cartas que o matemático e físico veneziano Giovanni Battista Benedetti escreveu ao compositor renascentista Cipriano de Rore nas quais incluiu algumas propriedades do som na sua teoria da consonância dos intervalos musicais, reunindo a física acústica e a harmônica.

Contudo, ainda na Antiguidade grega, no século IV a.C., uma corrente com conhecimento tanto das noções pitagóricas quanto peripatéticas propôs uma concepção propriamente musical da harmônica: a filosofia da música de Aristóxeno de Tarento. 


\section{CAPÍTULO IV}

\section{ARISTÓXENO E O LUGAR DA AISTHESIS NA HARMÔNICA}

\section{Pequena nota biográfica}

Aristóxeno (C. 375-300 a.C.) nasceu em Tarento durante os anos em que lá vivia Arquitas, na época, um político influente da cidade. Ele iniciou os estudos de música com seu pai, Spintharos, amigo de Arquitas, e que compartilhava das ideias da escola pitagórica. Ainda jovem, foi para Atenas, onde passou a estudar com Xenófilo de Cálcis, aluno de Filolau, até tornar-se um dos mais eminentes alunos de Aristóteles, a ponto de pleitear ser seu sucessor no Liceu, o que não ocorreu, tendo a posição sido ocupada por Teofrasto.

De acordo com a compilação enciclopédica Suda ${ }^{32}$, Aristóxeno escreveu 453 livros sobre música, filosofia, história e educação. Pela amplitude de seu pensamento musical, na Antiguidade, ficou conhecido como o Mousikós.

Quatro obras de Aristóxeno abordam o tema do pitagorismo: Sobre Pitágoras e seus seguidores, Sobre a vida pitagórica, Preceitos pitagóricos e Vida de Arquitas. Nenhuma sobreviveu completa, mas são encontrados fragmentos delas em autores posteriores. Esses fragmentos são considerados valiosos para o estudo do pitagorismo pelo fato de Aristóxeno ter vivenciado de perto o ambiente em que se debatiam tais ideias e por ele ter sido também um peripatético. Os estudiosos consideram que por esse motivo seus comentários apresentam uma visão mais próxima da realidade da escola

${ }^{32}$ A Enciclopédia Suda está disponível on-line em www.stoa.org/sol. 
pitagórica do que aquela difundida pelos sucessores de Platão ${ }^{33}$. O fato é que isso proporciona ainda mais autoridade às críticas que Aristóxeno fará aos procedimentos pitagóricos aplicados à música.

Sua obra central, Elementos de harmônica, oferece à ciência musical uma nova perspectiva marcando uma ruptura profunda com

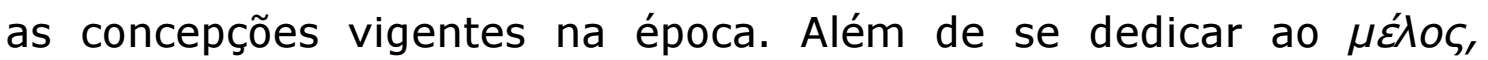
Aristóxeno escreveu sobre métrica e instrumentos, porém muito pouco restou desses escritos. Sobreviveu, no entanto, um grande trecho a respeito da rítmica, de data posterior aos Elementos de harmônica. Autores como Gibson consideram que foi Aristóxeno quem estabeleceu a distinção entre rítmica e métrica (2005, p. 77).

No que tange aos Elementos, vários estudiosos discutiram a ordem dos livros que compõem a obra, colocando em cheque a tradição manuscrita que os agrupou dessa forma. No entanto, para este estudo, consideraremos a ordem tradicional em três livros, tal como editada por Rosetta da Rios, e as referências apresentadas serão as da catalogação feita por Meibom ${ }^{34}$.

\section{A proposta aristoxeniana}

Em Elementos de harmônica fica evidente a escolha de Aristóxeno em favor da filosofia aristotélica, desse modo avançando e manifestando uma nova posição em relação às suas origens pitagóricas. Aristóxeno move a harmônica de uma perspectiva cosmológica universalista para um quadro especializado, mais claramente técnico.

\footnotetext{
33 Ver, a esse respeito, o verbete "Pythagoreanism", de Carl Huffman. In: The Stanford Encyclopedia of Philosophy, 2008.

${ }^{34}$ Para um histórico detalhado das propostas de organização do livro, estrutura do texto e origens dos manuscritos, ver Bélis, 1986, p.24-52.
} 
Um trecho do primeiro parágrafo do Livro II de Elementos de harmônica apresenta uma visão clara e precisa das mudanças propostas pela teoria musical de Aristóxeno:

"Como um todo, entendemos a Harmônica como a teoria de todos os $\mu \varepsilon ́$ los e de como a voz estabelece, de maneira natural, os intervalos, tensionando-se ou distendendo-se. Para nós, o

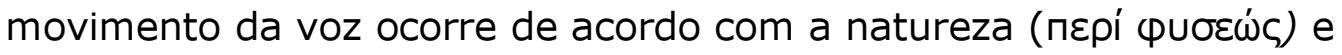
os intervalos não se estabelecem ao acaso.

"Acerca dessas coisas, tentamos apontar demonstrações de acordo com os fenômenos, não como os antecessores, que divagavam e desviavam-se da percepção sensível (aïơnбıc) como se ela não fosse precisa, maquinando causas no âmbito do intelecto (vońtas

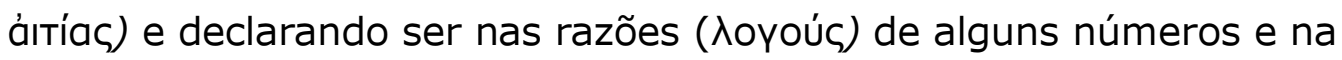
velocidade de outros que surgem o grave e o agudo; elucubrando discursos confusos e contrários aos fenômenos. Eles dão respostas oraculares sem causa nem demonstração em relação a cada coisa, e nem bem enumeram os fenômenos. Nós buscamos adotar os princípios que são evidentes aos que conhecem música e demonstrar o que procede a partir deles" (Meibom, 32, 6-22).

Nesse parágrafo estão contidas as críticas às teorias matemáticas e acústicas que, para Aristóxeno, não deveriam fazer parte da harmônica. Ao mesmo tempo, ele define seus princípios a partir de uma necessidade da natureza, de acordo com o modelo de ciência natural preconizado por Aristóteles.

Aristóxeno não vai procurar resolver os impasses da teoria pitagórica; sua ciência será construída sobre uma nova base. Para ele, a natureza do $\mu \varepsilon ́ \lambda$ oৎ nada tem a ver também com a produção, emissão, propagação ou audição do som. O movimento da voz, sua tensão e seu repouso, ocorre em um espaço especificamente musical e geométrico. 
O primeiro ponto analisado em Elementos de harmônica é a voz, definida segundo o lugar que percorre, seu tónos (topos). Ele diferencia duas espécies de movimentos tópicos da voz, de acordo com a continuidade ou a descontinuidade dos tons. A voz falada tem

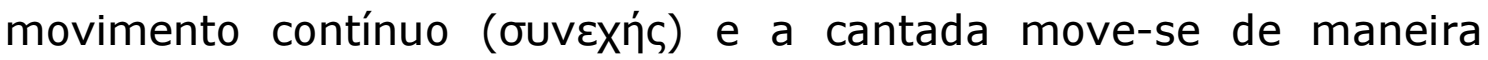

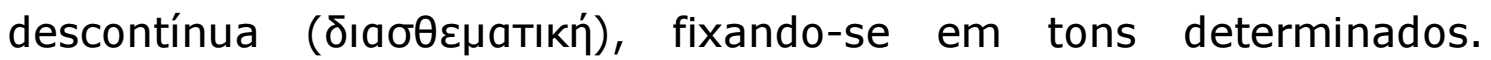
Portanto, não é a propagação do som ou seu desempenho físico que interessa a Aristóxeno. Sua preocupação é com a delimitação de um espaço específico do acontecer musical, e que incorpora a percepção do ouvinte. Ele deixa claro que, para a harmônica, não importa do que são feitos cada um dos movimentos. Isso é objeto da física. Para

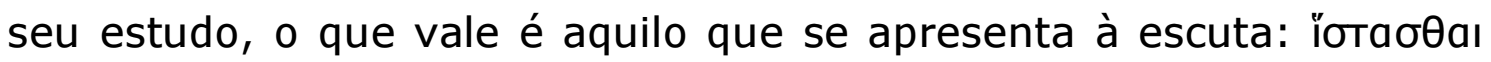
тṇ ákoñ (Meibom, 9, 14).

Ao cantar, a voz busca ao máximo parar em pontos fixos, pois quanto mais a emissão vocal for fixa, mais convincente afigurar-se-á a melodia à nossa percepção. Dessa condição, surgem cinco conceitos bem distintos. O primeiro dele, táoıç (tásis), é o lugar em que há uma certa prolongação e a estabilidade da voz; essa posição é

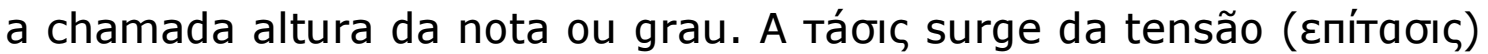

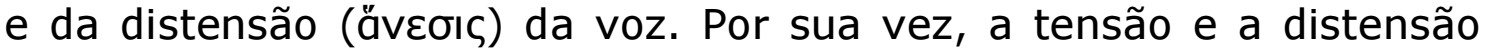

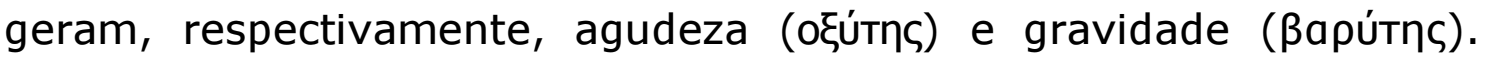
Tensão e distensão são causas; agudeza e gravidade, efeitos. Para distinguir os conceitos, Aristóxeno convoca os instrumentos de cordas:

"É evidente, para aqueles que não são ignorantes nos instrumentos, que levamos uma corda ao agudo, tensionando-a e, ao grave, distendendo-a, mas que, durante o tempo em que movemos a corda para conduzi-la ao agudo, a agudeza não poderá produzir-se. Só haverá agudeza quando a corda, levada através da tensão ao grau

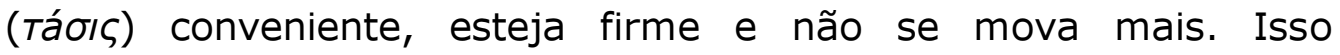
acontecerá quando a tensão tenha cessado e não exista mais, 
porque não é possível que uma corda se mova e ao mesmo tempo permaneça parada. Haverá tensão quando a corda apresentar movimento e agudeza quando a corda estiver parada". (Meibom, 11, $5-14)^{35}$.

Feitas as distinções, Aristóxeno marca uma vez mais a diferença da sua harmônica com as concepções acústicas da época: "Não nos deixemos turvar pelas opiniões daqueles que afirmam que o som é movimento, pois acabamos de dizer que, em certas circunstâncias, o movimento poderá não mover-se, mas permanecer fixo e imóvel". (Meibom, 12, 3-7).

Como dissemos, Aristóxeno abre seu tratado enfatizando que a harmônica é apenas um dos ramos da ciência musical ( $\mu$ ćlos

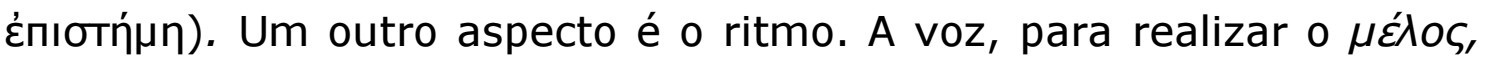
precisará de dois movimentos: katá tóv xpóvov (katá tón krónon), de acordo com o tempo, e katá Tóv tónov (katá tón tópon), de acordo com o lugar. A rítmica ocupa-se do primeiro movimento, a harmônica, do segundo. A teoria musical do Ocidente herdará essa

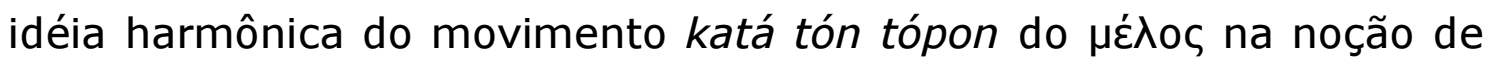
tessitura, âmbito ou ainda extensão vocal.

\section{A organização do estudo}

Aristóxeno define a harmônica como uma ciência que tem como

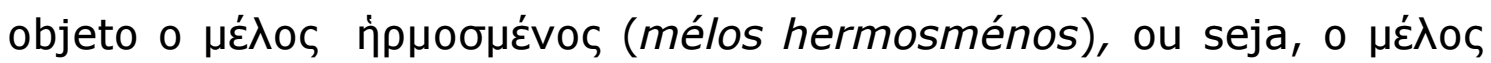
organizado de modo harmonioso, articulado, formoso. É necessário

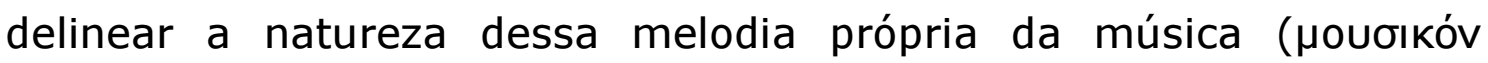

${ }^{35}$ A tradução para o português de epítasis e anésis por tensão e distensão não alcança com exatidão a ideia de direção do bmovimento implicada nas preposições gregas epí e anõ, dificultando a compreensão do trecho. 


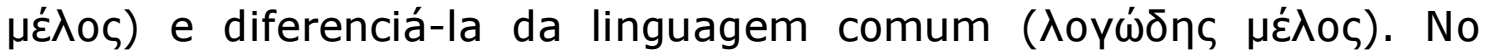

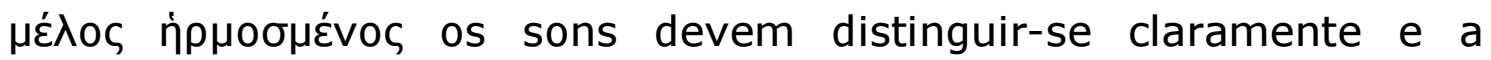
disposição dos intervalos obedecer às leis da harmonia: "nenhuma

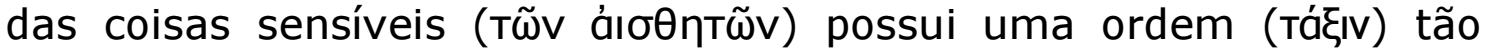
grande e de tal qualidade" (Meibom, 5, 31-32).

A harmônica deve, portanto, proceder de maneira organizada a fim de realizar suas demonstrações. Aristóxeno dá um exemplo de como isso deve ser feito e, como é característico de seu estilo, apresenta um retrato em negativo do processo e, ao mesmo tempo, um quadro vivo das aulas de Platão e Aristóteles:

"É melhor haver exposto, de início uniformemente, o modo de condução do estudo a fim de que, conhecendo de antemão o caminho que trilharemos e sabendo em qual parte dele estamos, o percorramos mais facilmente, e não aconteça de captarmos erroneamente $\mathrm{o}$ assunto.

"Isso acontecia, tal como Aristóteles sempre narrava a respeito, com a maioria dos que ouviam a palestra sobre o bem de Platão. Cada um vinha pensando captar algo acerca das coisas consideradas como o bem das pessoas, como, por exemplo, riqueza, saúde, força, em suma, alguma felicidade total e extraordinária.

"E, quando as palavras iam surgindo, sobre assuntos matemáticos, aritméticos, geométricos e astrológicos e, mais, a conclusão final de que o bem é uma unidade, isso parecia ser algo tão contrário à expectativa que alguns negligenciavam 0 assunto, outros censuravam. E por qual motivo? Pelo fato de não saberem com antecedência a natureza do objeto tratado, precipitavam-se, atraídos pelo título da palestra à moda dos sofistas, e acabavam boquiabertos.

"Mas se alguém, penso eu, tivesse estabelecido de antemão o todo, o aspirante à palestra poderia abandoná-la ou, se gostasse, ficaria, com base no que foi proposto. 0 próprio Aristóteles por isso mesmo 
fazia um prólogo para os que tinham intenção de ouvi-lo acerca das coisas que versava o estudo e o que ele era.

"Portanto, a nós parece melhor, tal como dissemos no princípio, expor antecipadamente o modo de condução do estudo" (Meibom, $30.15-31.13)$.

Aristóxeno quer organizar o conhecimento, decompor 0 conjunto, distinguir suas partes. Trata-se de obter uma visão clara, buscando fixar os pontos que servirão de pilastras para a construção do seu edifício harmônico. Ele propõe a classificação da harmônica em sete partes ( $\mu \varepsilon \dot{p} \eta)$, mas que são organicamente interligadas:

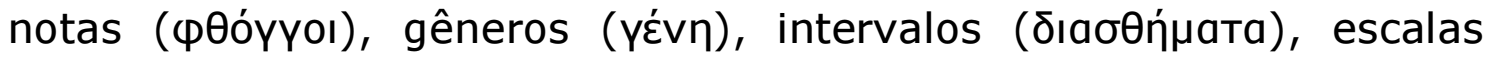

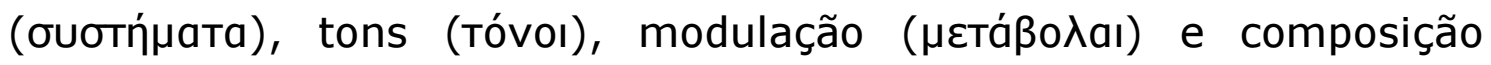

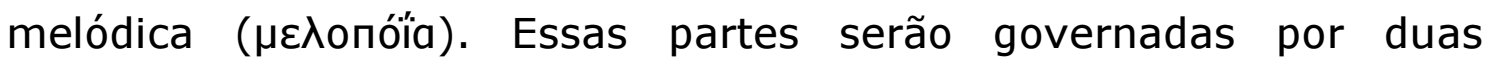
categorias adicionais que comporão o fundamento epistemológico de

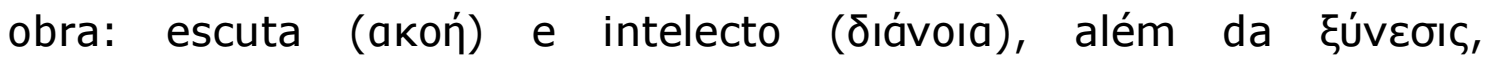
compreensão.

\section{As partes da harmônica}

Aristóxeno define a nota como a queda da voz em um

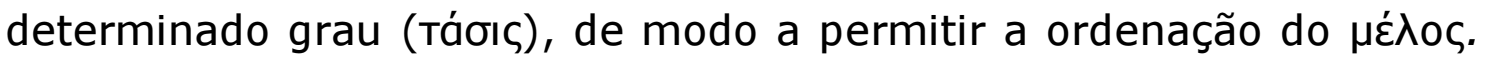
Os gêneros ( $y \varepsilon ́ v \eta)$ formam-se devido aos deslocamentos das notas em seus respectivos espaços no interior do tetracorde. A partir das notas fixas e móveis, os gêneros são classificados em diatônico, cromático e enarmônico, como já mostramos anteriormente. Mas eles não são apenas notas arranjadas em intervalos numa sequência estática de uma escala. Sua ordem obedece a padrões de sucessão diferentes numa escala ascendente ou descendente. Essa progressão dinâmica dos intervalos é detalhada no Livro III dos Elementos de Harmônica (Rios, 66-72). Com a sistematização, Aristóxeno reduziu 
as múltiplas possibilidades de arranjos das notas para uma série utilizável de gêneros.

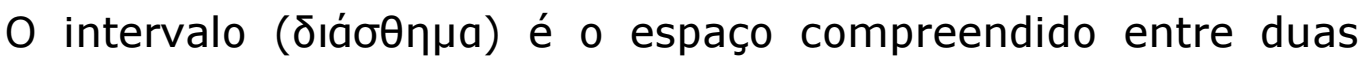
notas diferentes, ou seja, que não estão na mesma táoıc. A natureza

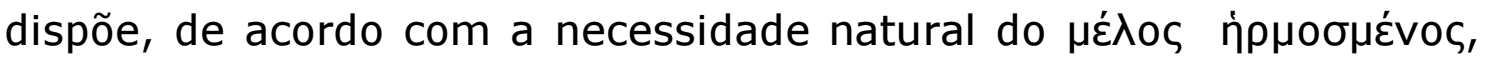
os intervalos musicais em uma ordem hierárquica (тákıৎ), estabelecendo assim as notas fixas e móveis formadoras dos gêneros: "a voz segue a natureza em seu movimento e não forma um intervalo ao acaso" (Meibom, 32, 8-11). Os intervalos não são apenas

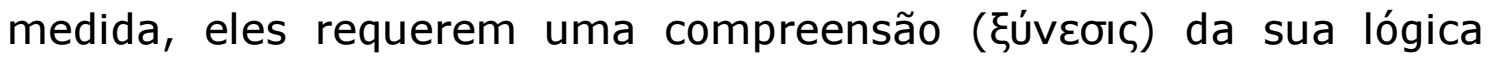

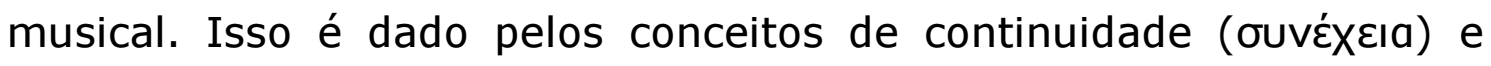

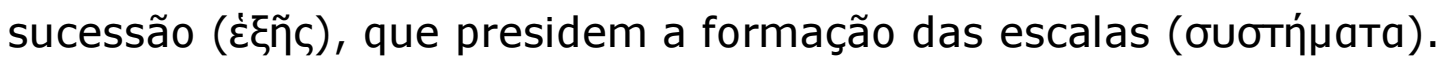

Na prática, os músicos não se valiam dos ouotńjata, mas dos Tóvoı, ou tonalidades. Muitos autores concordam que essa matéria dos tóvoı é uma das espinhosas da harmônica ${ }^{36}$. Eles estavam ligados aos modos gregos, com seus respectivos nomes étnicos: dórico, frígio, jônio, lídio e variantes e eram objeto da prática de músicos auletistas conhecidos como harmonicistas que os notavam em diagramas. O grupo era criticado por Aristóxeno: "a doutrina dos harmonicistas sobre as tonalidades é análoga ao modo como se contam os dias dos meses: assim, por exemplo, quando para os coríntios são dez, para os atenienses são cinco e ainda para outros oito" (Meibom, 37, 7-12). A parte que restou da doutrina dos Tóvoı de Aristóxeno é bastante fragmentária; sendo assim, costuma-se recorrer aos manuais de autores posteriores, especialmente a Introdução à harmônica de Cleônides, provavelmente do séc. II d.C., mas ainda assim ela permanece obscura. Possivelmente, Aristóxeno teria dado indicações de como empregar os tóvol e a partir de qual ponto de vista enunciar o seu número.

\footnotetext{
${ }^{36}$ Ver, a esse respeito, Barker, 2007, p. 55 e Winnington-Ingram, 1968, p. 49.
} 
Os Tóvol eram importantes para a teoria e a prática da

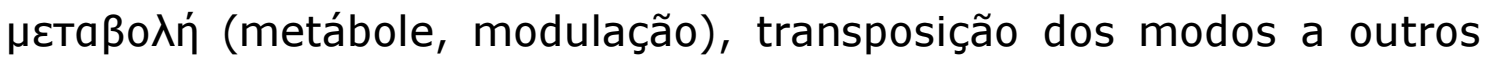

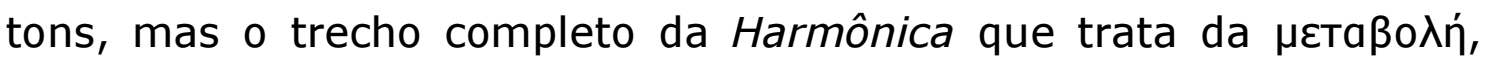
igualmente não sobreviveu. Explica Rios (1954, p.54) que os harmonicistas utilizavam bastante as tonalidades na sua prática musical com o ãudos e como a possibilidade de modulação num mesmo instrumento era muito pequena, era preciso recorrer a outro instrumento para a expansão da capacidade modulatória. Isso acontecia porque os modos gregos estavam atrelados às tonalidades. A tradutora afirma, com base no livro de Cleônides, que foi Aristóxeno quem tornou independente a noção de modo e tonalidade: "Aristóxeno, com as suas doze escalas, construiu um sistema de tonalidade homogênea e regularmente coligada que, por possuir uma grande e uniforme possibilidade de modulação, pode ser comparado àquele de Bach, e com isso, abriu novos caminhos para a melodia, que pôde fixar-se a qualquer altura (tom) possível, ao invés de restringir-se às sete escalas de transposição, que era o número dos modos" (Rios, 1954, p. 55). Talvez seja demais comparar Aristóxeno à Bach, contudo a uniformidade produzida pelo sistema aristoxeniano provavelmente estava ligada a sua concepção geométrica do espaço musical. Com a divisão igual da oitava seria possível uma maior homogeneidade das tonalidades, mas isso só será totalmente alcançado 2000 depois, com o temperamento musical.

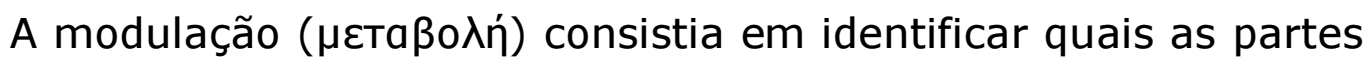
modulantes e quais as não modulantes. Isso era feito buscando-se o parentesco entre duas escalas ou modos por meio de intervalos e

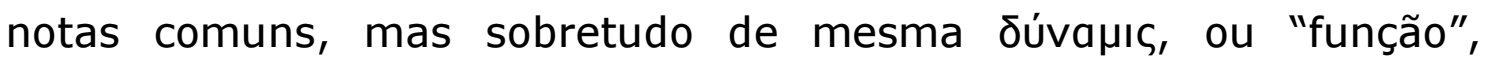
conceito que discutiremos adiante. Provavelmente a modulação era feita a partir da $\mu$ éon, nota que era referência para a afinação. Nos Problemas aristotélicos há uma passagem que compara a importância dessa nota com as conjunções gramaticais: "Por certo, todas as 
melodias de boa qualidade usam frequentemente a $\mu$ éon, e todos os

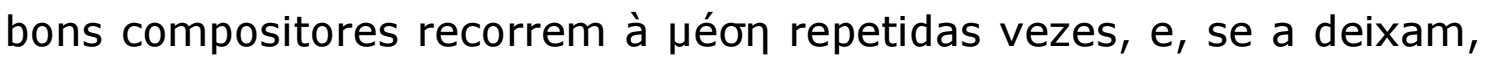
logo voltam a ela, e não recorrem a nenhuma outra nota dessa forma. Exatamente como se fossem eliminadas das frases algumas

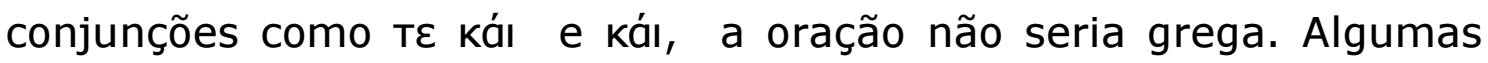
conjunções não são prejudiciais quando é necessário usá-las muitas vezes, se houver motivo, mas outras não, assim também a uéon, que dentre os sons é como uma conjunção, pelo fato de que seu som ocorre muito frequentemente, especialmente nas melodias de maior beleza" (Problemas, XIX, 919a, 19-28). Lembremos que o aperfeiçoamento dos instrumentos possibilitou uma expansão da capacidade de modulação e, inversamente, a maior sistematização da música impulsionou o desenvolvimento dos instrumentos.

Por fim, a última parte, e objetivo final da harmônica, é a

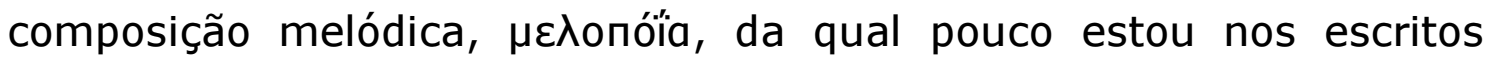
aristoxenianos.

Após definir o escopo da harmônica, Aristóxeno enumera as partes que não fazem parte dessa ciência e nesse sentido o mousikós ataca os harmonicistas que elaboravam extensos diagramas colocando todas as possíveis combinações de notas e derivavam essa notação da sua prática instrumental, especialmente do ãu入oc. Para Aristóxeno a capacidade de dizer em que modo está a melodia, a notação musical e a teoria do ãùoৎ não fazem parte da harmônica: "Assim como não é necessário, na métrica, que quem saiba escrever um metro jâmbico conheça perfeitamente o que é o jâmbico, assim

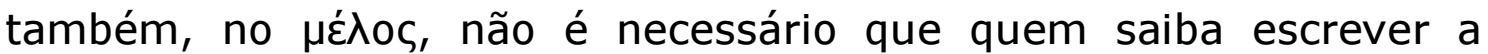
melodia frigia, conheça perfeitamente o que seja a melodia frígia" (Meibom, 30, 10-14). É importante ressaltar aqui que havia uma classe, a dos melógrafos, que dedicavam-se especialmente à escrita musical. O tarentino escreveu uma obra dedicada ao ãu入os, mas no caso da harmônica, ele considera que não devemos basear-nos em 


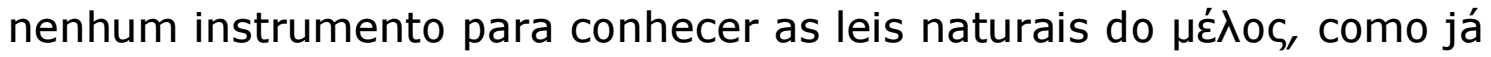
comentamos no capítulo relacionado aos instrumentos musicais.

\section{Os intervalos aristoxenianos}

Aristóxeno faz uma ampla classificação dos intervalos. Primeiramente, eles diferem em grandeza e também segundo sua consonância ou dissonância: "a segunda diferença é compreendida na primeira, porque todo intervalo consonante se distingue, em grandeza, de todo dissonante" (Meibom, 45, 1-3). Ou seja, como toda a estrutura da obra aristoxeniana, as duas classificações estão interligadas.

São oito os intervalos consonantes. Três deles são aqueles herdados dos predecessores: quarta, quinta e oitava, que é a reunião (e não a soma) da quarta com a quinta. Os outros cinco devem ser enumerados a partir da propriedade da oitava. Esse princípio, teorizado por Aristóxeno, diz que qualquer intervalo consonante, ao ser acrescido de uma oitava, é também uma consonância. Isso faz com que os intervalos de 11a. (quarta+oitava), 12a. (quinta + oitava), 15a. (oitava+oitava), 18a. (quarta+duas oitavas) e 19a. (quinta+duas oitavas) estejam no rol das consonâncias. Esse ponto é relevante, pois, para os pitagóricos, a $11^{a}$. não poderia figurar entre as consonâncias pelo fato de não ter expressão nem como razão múltipla nem como epímora, argumento sem valor para a lógica aristoxeniana.

Ao classificar os intervalos em consonantes e dissonantes, 0 tarentino não define propriamente essas qualidades, como vimos acontecer, por exemplo, nos Problemas aristotélicos em que a consonância é explicada como a fusão de dois sons, e como veremos na Divisão do cânone. Para Rios, isso não ocorre porque, para Aristóxeno, "consonância e dissonância são dados imediatos da 
percepção sensível" (Rios, 1954, p.24), e ponto final. Podemos dizer que o teórico, ao enunciar a propriedade da oitava, vale-se também

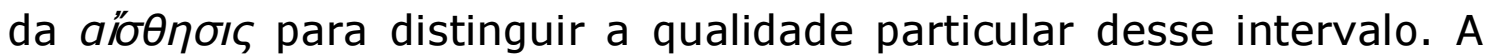
divisão de uma corda ao meio gera a oitava, como bem haviam observado os pitagóricos. Para os instrumentistas de sopros, a produção do intervalo pode acontecer por meio do recurso que chamaremos de "ultrasopro" (em inglês overblowing), ou seja, uma pressão maior no tubo de ar pode produzir o "milagre" da oitava. O intervalo é igualmente perceptível no canto, quando uma mesma linha melódica é realizada por vozes de homens simultaneamente a vozes de crianças ou mulheres. Weber ao fazer referência ao fenômeno da oitava observa que ela é sentida como uma "identidade em outro grau" (Weber, 1995, p. 105). Ao que parece, a constatação desse fenômeno foi suficiente para o tarentino enunciar a propriedade. Ele atenta ainda para o fato de que a duplicação da quarta e da quinta não gera intervalos consonantes, mas dissonantes.

Aristóxeno define o tom como a diferença de grandeza entre a quarta e a quinta e propõe sua divisão geométrica, em partes: "as partes do tom que se seguem a partir da diferença entre a quarta e a quinta são: a metade, dita semi-tom; a terça parte, dita diésis cromática; a quarta parte, dita mínima diésis enarmônica" (Meibom, $46,1-5)$. Ao rejeitar as razões numéricas como recurso de divisão da escala, o teórico foi um dos primeiros a propor uma distância homogênea entre os intervalos, posição precursora do temperamento igual. Essa afinação voltará a ser intensamente debatida no século XVI, por exemplo, nos escritos de Vincenzo Galilei, que teve acesso à primeira tradução dos Elementos de harmônica de Aristóxeno ${ }^{37}$. Aristóxeno não desenvolve na Harmônica a questão do meio-tom,

37 A primeira tradução dos Elementos de harmônica de Aristóxeno foi editada em latim em Veneza, no ano de 1562. A segunda, em italiano, é de 1593, e foi editada em Bolonha. 
limitando-se a enunciá-la; ela será desdobrada por autores posteriores como Cleônides e Aristides Quintilianus. (Mathiesen, 1999, p.529).

O mousikós prossegue com outras classificações dos intervalos: simples/compostos, por gênero e, finalmente, em racionais (ṕnтá) e

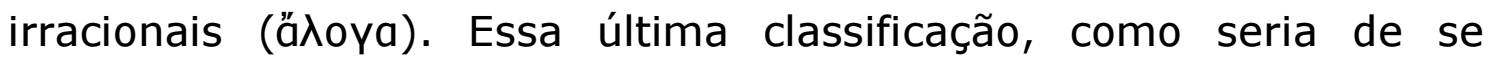
esperar, não tem nada a ver com as razões matemáticas. Ela serve para marcar uma vez mais suas diferenças com os pitagóricos. 0 intervalo é racional quando é executável musicalmente e é possível avaliar a sua grandeza. Por exemplo, os intervalos consonantes, 0 tom e outros intervalos comensuráveis com o tom. É irracional o intervalo que não cumpre nenhum desses requisitos.

\section{A coesão do $\mu$ źdos}

Aristóxeno não se limita à classificação, ele irá buscar conceitos que dêem conta de uma explicação. Existe a necessidade de mostrar como as partes da harmônica desenvolvem-se organicamente nas

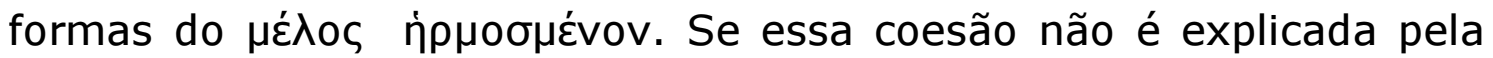
cosmologia pitagórica, devemos conhecer o que dá sustentação a essa estrutura harmônica.

Entre os conceitos propostos para dar conta da coesão do

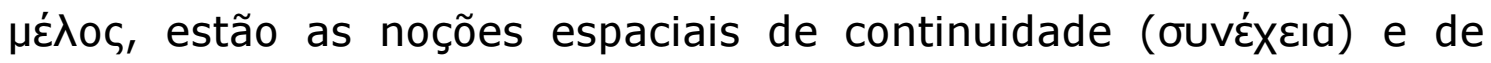

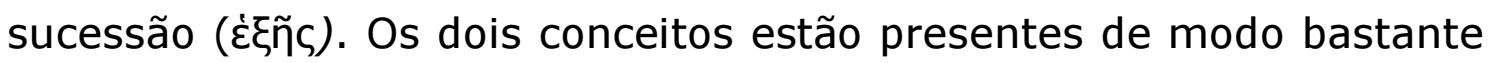
complexo na Física e na Metafísica de Aristóteles (Apud Bélis, 1986, p.153-154). Na бuvéxદıa os termos ao se tocarem formam uma única

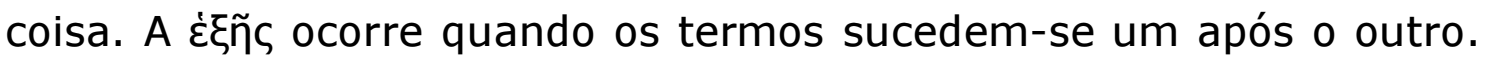
Esses conceitos estão presentes na ordenação das escalas, биот́́ната, permitindo a descrição dos encadeamentos dos tetracordes, que devem seguir a lei necessária e natural da ordenação melódica dos intervalos. Essas leis estão nos 26 silogismos 
demonstrativos que compõem o terceiro livro dos Elementos de

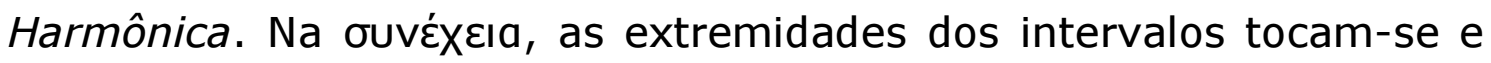

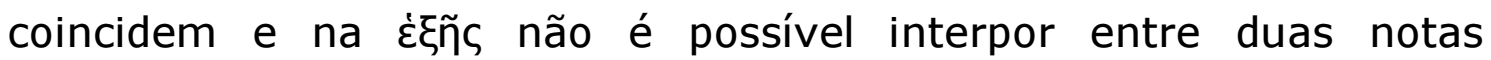
sucessivas na escala, uma nota intermediária. Para explicar a

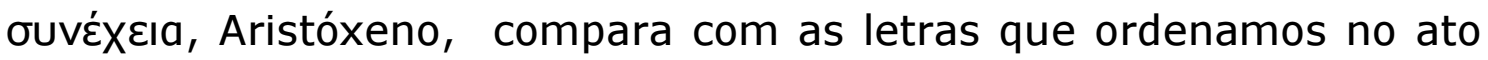
de falar. Pela "lei natural" colocamos em cada sílaba, primeiro uma letra, depois outra; igualmente, na melodia, a voz ordena os intervalos e as notas de acordo com a continuidade.

Outro conceito importante para a coesão do sistema harmônico

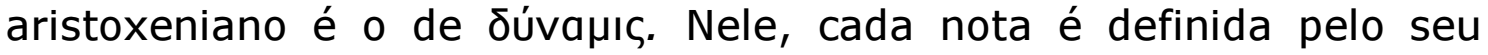
contexto ou, em termos modernos, pela sua função. A medida de um intervalo ou de um conjunto deles pode ser diferente, mas suas funções serem iguais. Inversamente, intervalos de mesmo tamanho podem ser ouvidos de modo diferente, caso difiram as suas funções.

$\mathrm{Na}$ organização harmônica tonal da música moderna, notas iguais e principalmente acordes - agrupamentos de três notas ou mais - possuem a potencialidade de desempenhar papéis diferentes, às vezes dentro de uma mesma música. Fazendo uma associação com as cores é fácil perceber que um amarelo "soa" de maneira diferente ao lado de um azul ou de um vermelho. É possível que a

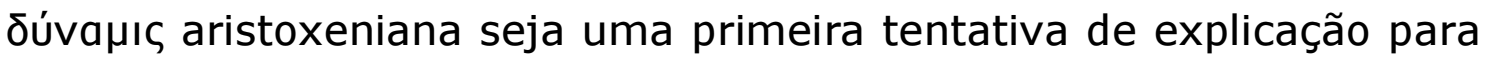
esse fenômeno na música.

Se o ouvido percebe a grandeza do intervalo, o intelecto capta

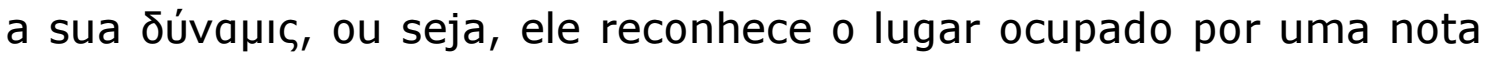
ou por um intervalo em uma escala dada. Desse modo, o espaço musical em que se move a voz, ou a melodia, é dividido de maneira geométrica, um espaço bem mais flexível que 0 dos cálculos aritméticos pitagóricos. Enfim, a percepção da estrutura musical é mais importante que sua medida.

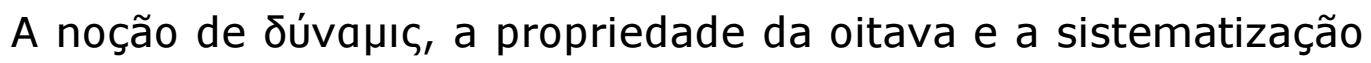
dos Tóvoı certamente aperfeiçoaram a prática de transposição. 


\section{A aïronoıs}

Ao formular a noção geométrica do percurso da voz de modo contínuo ou descontínuo, Aristóxeno chama a atenção para o fato de que esses dois movimentos devem ser observados de acordo com a

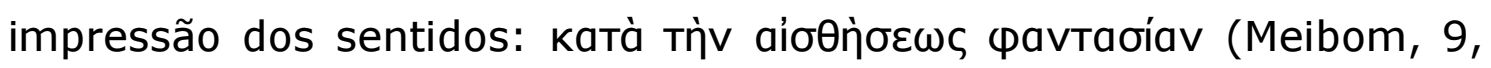

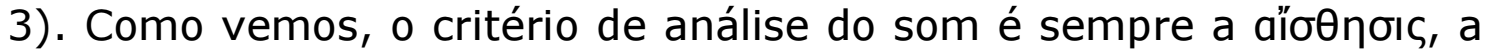
sensação. Ele não deixa dúvidas: "Para o músico, a exatidão da percepção sensível está quase na ordem de um princípio. Tanto é verdade que é impossível, quando não se tem o ouvido treinado, falar corretamente sobre aquilo que não se percebe" Meibom (33, 21-26).

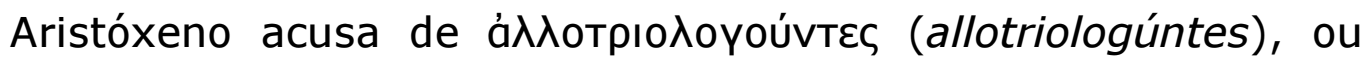
seja, argumentos estranhos, as soluções apresentadas por seus antecessores, pois elas são contrárias aos fenômenos, ou seja, àquilo que se apresenta aos sentidos. Os discursos são confusos porque não tomam como base a aïoӨnбıc. A ideia de uma oitava ser representada pela razão 2:1 é completamente estranha a essa ciência que Aristóxeno está buscando construir, para não dizer totalmente inútil. Aqui, a oitava é aquele som característico que ouvimos. Os princípios da harmônica, na obra de Aristóxeno, são aqueles evidentes aos que são experientes em música.

O autor Gaudêncio, da Antiguidade tardia (séculos III ou IV d.C.), reuniu em sua Introdução à harmônica aspectos das teorias pitagóricas e aristoxenianas. Na abertura da obra, ele escreve: "aquele que não ouve uma nota claramente e não exercitou a sua audição e veio ouvir estas palavras, deixe-o ir embora e fechar a porta para esses sons antes delas, pois seus ouvidos, embora presentes, serão interrompidos por um sentido que não conhece. Ao iniciarmos, falemos na voz daqueles treinados de maneira precisa pela experiência" (Apud Mathiesen, 1999, p.500). 
O objetivo do exercício do ouvido é o aperfeiçoamento da

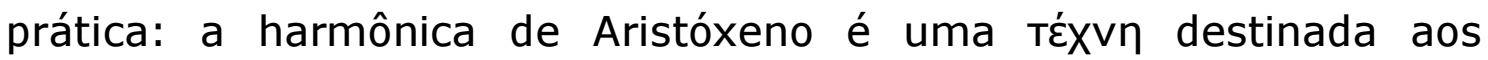
músicos. No que diz respeito à importância dada ao ouvido treinado, Bélis comenta: "Aristóxeno é, sem dúvida, um dos primeiros a abordar esse tema, e não sob forma de recomendação pragmática, mas dentro de uma argumentação filosófica" (Bélis, 1986, p. 205). Como diz Aristóxeno: "É necessário acostumar-se a julgar cada coisa com precisão; de fato, não podemos dizer, como se faz a propósito das figuras geométricas: 'seja esta linha reta'; não! Devemos abandonar esse hábito ao falarmos dos intervalos. Pois o geômetra

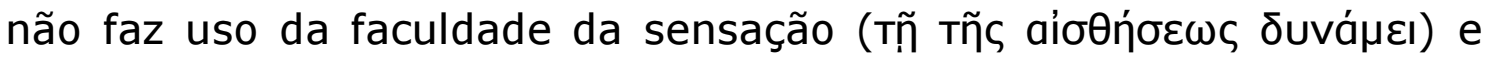
nem acostuma a sua visão a julgar bem ou mal, à reta, ao círculo, ou a outra destas figuras, isto sendo mais da competência do carpinteiro, do que trabalha no torno, ou outros técnicos que se exercitam nessas coisas" (Meibom, 33,10-21).

A representação da música pela matemática é rejeitada porque ela não ilumina as estruturas; pelo contrário, obscurece o que foi percebido. Referindo-se a isso, ele diz: "é evidente que nenhum desses procedimentos corresponde ao modo de representação da percepção sensível, porque essa distingue o gênero enarmônico e o cromático, considerando a semelhança de uma certa forma, não a grandeza de um certo intervalo" (Meibom, 48, 14-17).

O conceito de aïoӨnoıs é a diferença fundamental entre a filosofia aristoxeniana e a pitagórica. Por exemplo, o tom será definido a partir da diferença entre a quarta e a quinta, mas essa diferença não advém da subtração, da divisão ou de qualquer outra operação aritmética. A diferença que produz o tom, para Aristóxeno, é aquela que ouvimos claramente entre a quarta e a quinta. O fato dos intervalos serem duas consonâncias faz com que eles sejam mais facilmente reconhecidos e julgados pelo ouvido treinado e assim torna-se mais fácil determinar o tom a partir deles. 


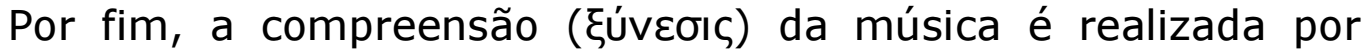

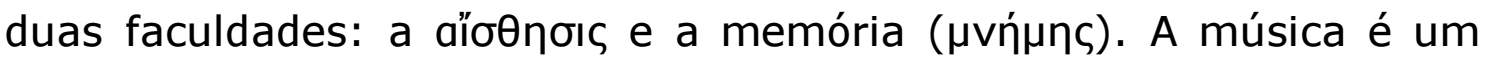
fenômeno que acontece no tempo, portanto para compreendê-la, "é necessário perceber (ouvir) o que transncorre e lembrar o que

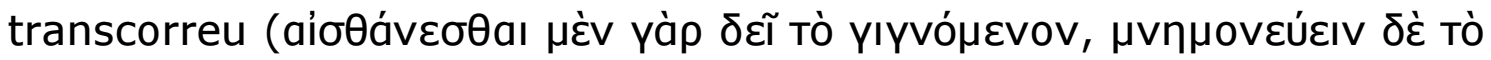
үعүovós)" (Meibom, 39, 29-35). Mais uma vez, fica evidente a distância que separa a filosofia da música aristoxeniana das formulações dos pitagóricos e harmonicistas de seu tempo.

\section{O diálogo com Aristóteles}

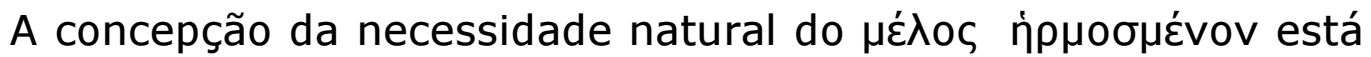
em perfeita sintonia com a filosofia aristotélica, tal como encontramos, por exemplo, no tratado Sobre os céus: "O deus e a natureza não fazem nada inutilmente" (Apud Bélis, 1986, p. 140). Mas há uma diferença fundamental entre essa necessidade de ordem

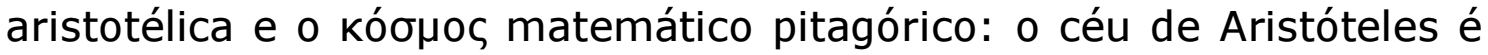
o céu que se apresenta aos sentidos. Assim também a música de Aristóxeno.

O modo aristotélico de conceber o som e a escuta abriu novas perspectivas para a harmônica. Aristóteles ensaiou penetrar em seus domínios, mas foi claro ao dizer que não tinha pretensões à música, deixando essa função para alguém com mais competência. Ele fez uso dos instrumentos musicais como recurso de metáfora em sua Metafísica (1046a), chamando a atenção para uma relação dialética entre duas partes, como, por exemplo, entre o instrumentista e o

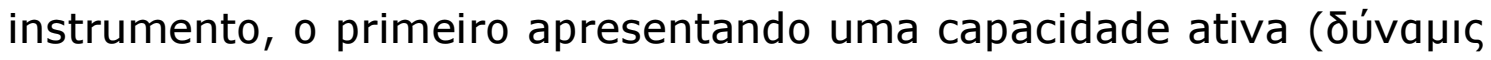

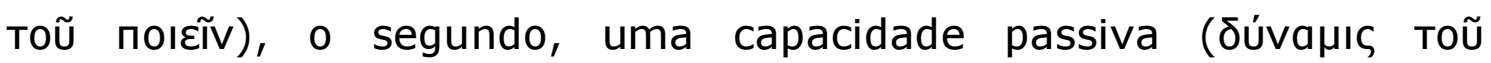
пáoXعıv).

Zingano, em seu estudo da doutrina da sensação no De anima, diz que Aristóteles analisa a percepção como "uma atividade da alma 


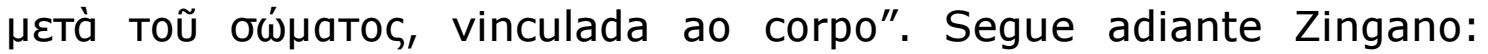
"Embora a percepção não possa ocorrer sem certas alterações de certos órgãos, em função de um objeto específico, a percepção de algo não é unicamente (ou idêntica a) estas alterações. Aristóteles assinala com frequência que a percepção é 'uma certa afecção', náoXદıV $\mathrm{TI}$, querendo dizer com isto que não se reduz ou não é somente esta afecção. Ela é, e isto fundamentalmente, uma alteração ou afecção dos órgãos sensitivos em que se realiza uma faculdade ou

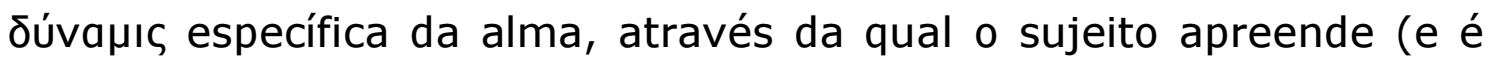
consciente desta apreensão) a forma sensível dos objetos" (Zingano, 1998, p. 54).

Aristóxeno talvez tenha buscado a elucidação desse processo

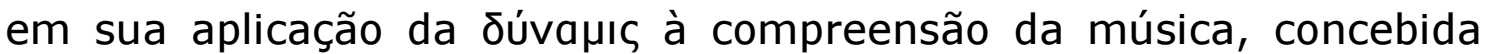
verdadeiramente como um aiönтóv, um objeto percebido pelo ouvido. O ouvido que é afetado, movido, pelo som musical, é o princípio da harmônica de Aristóxeno, mas há uma intervenção de outra instância para que se complete o processo da percepção musical: "a teoria refere-se a todos os $\mu \varepsilon \dot{\lambda}$ os da música, que ocorrem na voz e nos instrumentos. O estudo encaminha-se de modo duplo: em direção à escuta e à inteligência. Pela escuta (akoń), distinguimos as magnitudes ( $\mu \varepsilon \gamma \varepsilon \dot{\theta} \eta)$ dos intervalos; com o intelecto (סı́́voıa),

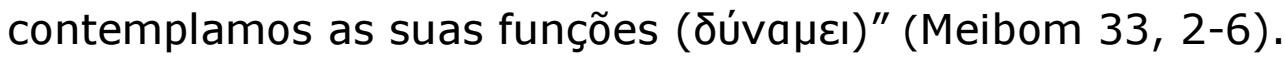

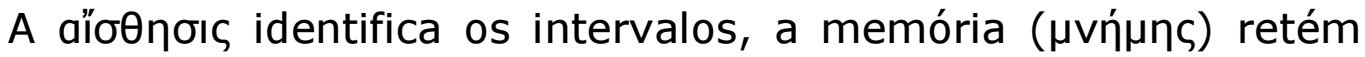
as impressões, já a dıávoıa capta a configuração das notas e das

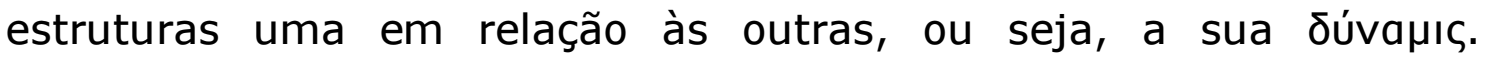
Certamente esses conceitos-chave da teoria de Aristóxeno advêm das discussões sobre a natureza da percepção nos círculos aristotélicos. 


\section{Ressonâncias de Elementos de harmônica}

Os teóricos subsequentes da Antiguidade, como Cleônides, Gaudêncio e Aristides Quintiliano, vão adotar o tratado de Aristóxeno como fonte de estudo da música grega antiga, mas, com exceção de Ptolomeu $^{38}$, vão deixar de lado a sua filosofia. Assim, a parte mais rica do seu legado praticamente desapareceu, enquanto as sete partes referentes à Téxv $\eta$ musical foram expandidas e rearranjadas, de modo que boa parte do que se conhece dela hoje deve-se a esse trabalho.

Quando a filosofia de Aristóxeno aparecia, era muitas vezes mal interpretada e ressaltada apenas a sua ênfase na sensação. Contudo, como bem observa Bélis: "Aristóxeno está tão longe de negligenciar o exercício do pensamento (apesar dos ditos de Boécio), quanto de relegar um lugar modesto à sensação. E por duas razões: primeiro, ele acredita ser necessário que em cada coisa haja uma análise teórica ou uma definição pela sensação, mas se a impressão auditiva e a teoria estão em contradição, a teoria deve ceder" (1986, p. 210). Essa postura está em acordo com o princípio empirista de Aristóteles: se a experiência se opõe à teoria, é preciso modificar a teoria.

Boécio, na sua obra Instituições musicais, afirma que Aristóxeno não usa a razão e concede à sensação todo o crédito (Apud Bélis, 1986, p.227 nota 65). Talvez devido à influência dessa interpretação de Boécio, só no século XVI os escritos desse autor maior serão estudados abertamente e com merecida atenção.

A divisão da harmônica em sete partes será o fundamento do programa de musicologia e de ensino para as próximas gerações. A divisão em partes deve ser de cunho lógico e pedagógico, o que não significa que as partes sejam anteriores ao todo. $O \mu \varepsilon \dot{\lambda}{ }_{0} \varsigma$

\footnotetext{
${ }^{38}$ Ptolomeu buscará contemplar a percepção musical na sua Harmônica, mantendose, no entanto, fiel às razões matemáticas pitagóricas.
} 


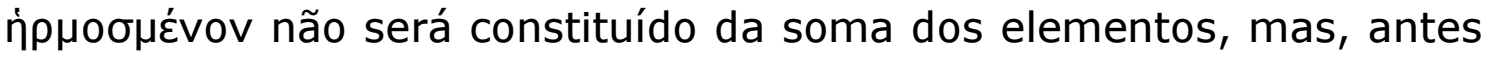
de tudo, será uma síntese. O objetivo final da harmônica de

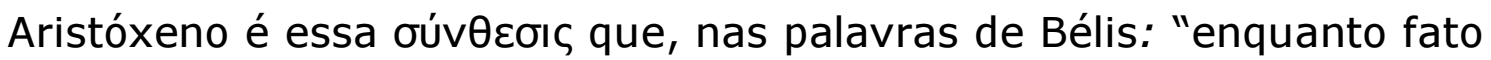
da natureza, de uma necessidade absoluta e de uma perfeição

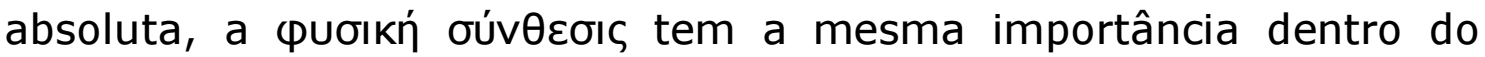
sistema de Aristóxeno que a noção de àpuovía entre os pitagóricos" (1986, p. 150).

A obra de Aristóxeno será um divisor de águas na teoria musical da Antiguidade. Suas críticas às influentes concepções pitagóricas colocaram em cheque alguns pressupostos teóricos da ciência daquele tempo. Mesmo a posição de Aristóteles, no que dizia respeito à contestação do pitagorismo limitava-se à metafísica e à astronomia (Metafísica, 986a); no que tange às razões pitagóricas, ele estava de acordo que elas fossem as causas das consonâncias. É interessante que Aristóxeno em nenhum momento questiona as causas das consonâncias, ele apenas afirma que não é disso que trata a ciência particular da harmônica.

Essa ciência independente exclui de suas análises os instrumentos, a performance, a escrita e as razões numéricas. Ao invés de falar em comprimento da corda, refere-se a partes da escala, insinuando uma contaminação da música, com seus números discretos, pela ciência das magnitudes contínuas e, por sua vez, pela ideia de infinito e incomensurável. E o que era mais ameaçador: tudo isso tinha por fundamento a natureza. Em uma época em que a música era vista como a própria afinação do mundo, isso deve ter tido um impacto considerável.

A obra de Aristóxeno expôs a crítica feita aos pitagóricos de que sua ciência apresentava uma visão estreita da harmônica, tentando comprimir o mundo físico dos sons nas razões numéricas. Contudo, a descoberta da teoria acústica tinha uma força imensa, o que era realçado pelo caráter sagrado do discurso. A importância da 
providência divina na descoberta não deve ser menosprezada como atesta o mito dos martelos de Pitágoras. De qualquer modo, o alcance e o refinamento dos conceitos aristoxenianos irá forçar uma especialização do discurso pitagórico. 


\section{CAPÍtuLO V}

\section{A DIVISÃo DO CÂNONE}

\section{A longevidade da concepção pitagórica}

No mundo grego do século IV a.C. as matemáticas passaram por um intenso processo de desenvolvimento, culminando na ciência dos Elementos de Euclides de Alexandria (360 a 295 a.C.). O matemático é referido em alguns escritos da Antiguidade como sendo o autor do pequeno tratado musical $A$ divisão do cânone. Na obra, os princípios matemáticos são pitagóricos, remontando a suas origens no século VI a.C., contudo, a maneira de expor os argumentos demonstra ter sido elaborado num período posterior. Apesar do costume de atribuí-la a Euclides não há nenhuma evidência documental ligando-a ao matemático.

Existem duas versões em grego e uma em latim. As versões em grego confirmam a autoria de Euclides: uma forma mais longa, nos manuscritos que acompanham a Introdução à harmônica de Cleônides, e outra mais breve no comentário de Porfírio à Harmônica de Ptolomeu, do século III d.C. A versão em latim está presente no Instituições musicais de Boécio, que não atribui a obra a ninguém.

O tratado evoluiu até seu estágio final nos séculos XIII e XIV, quando possivelmente eruditos bizantinos acrescentaram diagramas geométricos à obra. A partir de Bizâncio a obra chegou a Veneza, e essa será a forma que será lida no Ocidente. Essa tradição que atravessou a Idade Média até o final do Império Bizantino, o que inclui os manuscritos preservados em árabe, também concedia a autoria ao alexandrino. Contudo, para Barbera, que fez um estudo detalhado da trajetória do texto, "seria imprudente afirmar definitivamente que a Divisão foi ou não foi escrita por Euclides", e 
segue adiante: "nós estamos lidando aqui com convicções básicas de matemática e acústica, o tipo de verdades que podem e devem ser aprendidas e no mínimo memorizadas. E também estamos lidando com pitagóricos e neopitagóricos, que foram famosos por seus slogans, sociedades secretas, e adesão a uma ßíos, uma regra ou estilo de vida. Isso conta na composição da Divisão: nós podemos imaginar uma semente de verdades e crenças acústicas da qual brotam proposições em um dado período, proposições que são instâncias em um sistema musical de verdades essenciais. Uma teoria musical dessa natureza poderia ter sido transmitida oralmente, embora tenha sido em algum momento formulada no estilo euclideano e escrita". Depois de escrita, a obra seguiu sua trajetória até a Bizâncio medieval, onde possivelmente houve o acréscimo dos desenhos das linhas e a acomodação do texto aos diagramas. Apesar de parecerem pequenos, em alguns casos esses acréscimos transformam proposições aritméticas em geométricas. Para Barbera, "esse tipo de atenção em uma data tão remota atesta a vitalidade do material contido no tratado" (Barbera, 1991, p. 35).

De modo extremamente objetivo e sintético, o tratado aborda a natureza do som, define consonância e dissonância, apresenta as razões matemáticas no estrito estilo euclidiano e apresenta um guia para a localização das notas no cânone. Na forma mais completa em grego, divide-se em quatro partes: introdução, nove proposições puramente matemáticas, sem nenhuma referência musical, as proposições musicais decorrentes e o método final de divisão do cânone.

\section{A natureza do som}

$\mathrm{Na}$ obra, encontramos os elementos da mais antiga teoria musical e acústica do Ocidente, com seus primeiros experimentos e 
tentativas de compreender o som. Mas a forma de exposição dialoga com as idéias contemporâneas, em alguns momentos, diretamente com Aristóxeno. As razões musicais pitagóricas são descritas de maneira técnica e especializada sem qualquer menção à cosmologia. Contudo, como veremos, algumas proposições só ganham lógica se for estabelecida a conexão com o princípio da тєтрактúৎ pitagórica.

Na seção introdutória do livro encontramos uma demonstração dessa filiação arcaica pitagórica na afirmação: "Se alguma coisa for ouvida, é necessário que antes tenha havido percussão ( $\Pi \lambda \eta ү \eta ́ v) ~ e$ movimento" (3-4, p. 114). Segundo Barbera, a frase pode ser considerada como remontando ao próprio Pitágoras, pois Porfírio cita um certo Heráclides que, por sua vez, cita Xenócrates que menciona uma frase quase igual atribuindo-a a Pitágoras (Barbera, 1991, p. 49). De qualquer modo, ao iniciar a exposição mencionando a questão do movimento físico, o tratado pode estar buscando dar uma resposta às críticas de Aristóxeno.

Se o som é produzido pelo movimento, as notas ( $\varphi$ ○óyyoı) são definidas como uma sequência de movimentos, que possuem partes

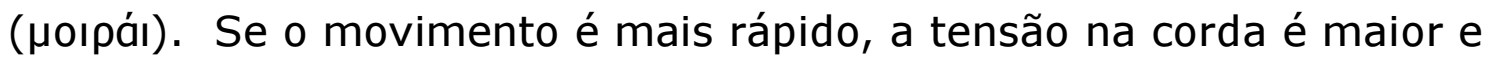
o resultado é uma qualidade de som mais agudo; ao contrário, se o movimento for rarefeito, ou em linguagem moderna, se a frequência da vibração da corda for mais baixa, a tensão será menor, e o som será mais grave. Sabemos que não é possível ao olho humano perceber esses movimentos, muito menos identificar suas partes, mas na obra elas têm um número. Portanto, quando esses sons tiverem uma altura precisa, como uma nota musical, será possível

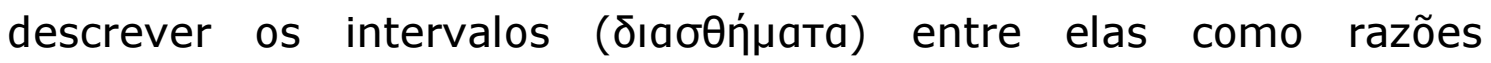
numéricas.

Nota-se que essa teoria é um aperfeiçoamento da teoria de Arquitas. Como aponta Lippman, o que chama a atenção nessa nova descrição física do som é que "não são as seções da corda que 
permitem tal mensuração, mas as durações de vibração numericamente divisíveis, que estão conectadas a uma sucessão de impulsos agindo no ouvido" (Lippman, 1992, p. 154). Portanto, movimento mais denso produz notas mais agudas e mais rarefeito, notas mais graves. E, como o som é feito de partes, para a Divisão do cânone, distender ou tensionar as cordas para afiná-las será

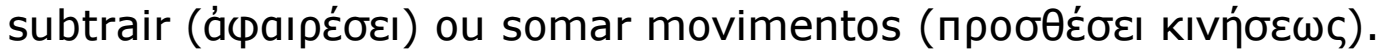

$\mathrm{Na}$ última metade da introdução, o texto estabelece que as notas são consonantes ou dissonantes em relação umas às outras e os sons são consonantes quando fundem-se num único. As duas afirmações dão a entender que há um sujeito que ouve essas notas. A obra parece dar um voto de confiança à percepção. Boécio, na cópia do tratado, chega a acrescentar a palavra "agradável" (suavem) à mescla de sons consonantes. Mas a explicação de tal fenômeno é de ordem aritmética: "todas as coisas feitas de partes (como as notas) relacionam-se umas com as outras por razões numéricas" (114, linha 15). Se há consonância ou dissonância, as razões numéricas irão demonstrar.

Após esse pequeno estudo da causa dos sons e das consonâncias, o tratado enumera de maneira hierárquica as razões em múltiplas, superparticulares e superpatientes. Apenas as razões múltiplas e superparticulares podem ser consonantes. Contudo, como veremos, isso não vai significar que todas as razões múltiplas e superparticulares expressem consonâncias, mas apenas aquelas que apresentarem as relações da тєтрактúc pitagórica.

\section{O rigor da canônica}

Após a Introdução, seguem-se as nove primeiras proposições que expõem teoremas concernentes às razões entre os intervalos, sem fazer qualquer referência à música. Mas fica claro que sua 
função é preparar o caminho para as concepções musicais que aparecerão a partir da proposição 10.

As razões múltiplas $(m n: n)$ referem-se às oitavas $(2: 1)$ e as superparticulares $(n+1: n>1)$ às quartas ( $4: 3)$ e às quintas (3:2). As razões musicais podiam ser demonstradas nas distâncias (intervalos) entre dois pontos numerados no cânone, mas neste momento da obra elas são demonstradas por meio de diagramas, segmentos de reta representando um instrumento multicordas. Existem, no entanto, ainda algumas dúvidas sobre a data exata em que esses diagramas tenham sido feitos, provavelmente na Bizâncio medieval tardia, conforme já apontamos (Barbera, 1991).

As duas primeiras proposições tratam da duplicação da oitava, unanimidade entre pitagóricos e aristoxenianos, ainda que as linguagens sejam radicalmente diferentes. Já a proposição 3 segue um caminho diferente: "em uma razão superparticular não existe número, nem um, nem mais de um que o divida proporcionalmente". Essa prova havia sido apresentada por Arquitas, como vimos, e serve para demonstrar aritmeticamente que não é possível dividir o tom ao meio. Se não há um termo médio entre dois de uma razão epimórica (superparticular, ou seja, a quarta e a quinta), não é possível dividir o tom (9:8). Como já dissemos, esse cálculo levaria a um número irracional, ou seja, não redutível a uma razão.

O tom é um exemplo de uma razão epimórica que não é considerada consonância. Isso mostra que além de ser múltipla ou superparticular, para fazer parte do rol das consonâncias, era necessário ainda participar das razões formadas pelos números 1,2 , 3 е 4, da тетрактúc.

A proposição 4 é uma confirmação aritmética da percepção aristoxeniana de que a quinta e a quarta dobradas não produzem consonâncias. Para Aristóxeno, as duas consonâncias não compartilham da propriedade da oitava. O texto euclidiano não fala 
em notas musicais, diz apenas que as razões resultantes não serão nem múltiplas nem superparticulares. E assim têm continuidade as proposições. Por exemplo, a proposição 8 afirma que se de um intervalo sesquiáltero for subtraído um sesquitércio, o resultado será um intervalo sesquioitavo. Em linguagem musical, isso que dizer que a diferença entre a quinta e a quarta é de um tom. Nessas primeiras proposições, a ênfase está em mostrar que tudo aquilo que é percebido empiricamente pela audição deve ser traduzido em linguagem matemática. O texto apresentando por Boécio é interrompido na última das proposições exclusivamente matemáticas, a de número 9.

\section{Os corolários musicais}

Nas proposições 10 e 11 entram finalmente as notas musicais. É possível pressupor a partir delas o sistema tonal grego abrangendo duas oitavas. Na proposição 10 reconhece-se que a dupla oitava, que é representada pelos nomes das notas, é uma consonância, portanto deve ser uma razão dupla ou epimórica. A conclusão é genial: não pode ser epimórica pois ela tem meio, que seria a oitava simples. Portanto, é dupla. Percebe-se que houve uma transição para o reconhecimento auditivo dos intervalos, mas aplicando rigorosamente aquilo que foi aprendido nas primeiras nove proposições. A Divisão aspira a ser um manual técnico. Em uma oitava, é possível perceber que a quinta é maior que a quarta auditivamente, mas não apreendemos sensivelmente que a diferença entre elas é de 9:8, nem que a quarta é $4: 3$ e a quinta 3:2. Cabia à aritmética desvelar essas relações.

A proposição 11 apresenta uma diferença importante em relação ao sistema aristoxeniano. Com base nos argumentos aritméticos, demonstra que a oitava é menor que seis tons, a quinta 
é menor que três tons e meio e a quarta, menor que dois tons e meio. Aristóxeno diz literalmente: "é evidente que a quarta é composta de cinco semitons" (Meibom, 57, 7-8), o que significa que ela é exatamente dois tons e meio. Isso é possível porque Aristóxeno não via problemas em dividir o tom ao meio.

A Divisão do cânon não menciona, mas com base nesses argumentos da relação direta entre as razões múltiplas e epímoras e as consonâncias, comentadores posteriores como Boécio excluirão a quarta dupla, ou seja, o intervalo de quarta mais a oitava, do rol das consonâncias, pois a razão resultante da soma de 2:1 e 4:3, ou seja, 8:3, não é nem múltipla nem epímora. Portanto, a 11a. ficará excluída do rol das consonâncias. Posteriormente, esse fato será a causa de um confronto entre o empirismo e o racionalismo na antiguidade. Ptolomeu será um dos que criticará os pitagóricos por deixarem seu racionalismo interferir na percepção sensorial ${ }^{39}$.

\section{Dividindo o cânone}

As duas proposições finais da obra são um método para a localização das notas no instrumento. A primeira delas pressupõe 0 genro enarmônico, mas o cânone não é explicitamente mencionado. A passagem final estabelece os tamanhos necessários para fazer de fato a marcação no monocórdio no gênero diatônico, primeiro localizando as notas fixas, e, em seguida, as móveis.

Os pitagóricos buscaram uma afinação musical ideal que complementasse a sua filosofia dos números e criaram o instrumento para esse fim: o monocórdio, ou cânone, no qual era possível visualizar a proporcionalidade inversa entre a altura musical e a corda vibrante como segmentos em uma régua. Por trás do cânone havia uma ideia original: a de uma ferramenta construída para a realização

\footnotetext{
${ }^{39}$ Ver, a esse respeito, Barbera, 1984.
} 
de um experimento científico, mas que partia de um fato sensorial, a percepção musical.

No monocórdio, era possível esquecer totalmente outros fatores ligados à produção do som musical. Isolar um fato, apenas a altura, como em um espaço ideal. A Divisão do cânone não leva em

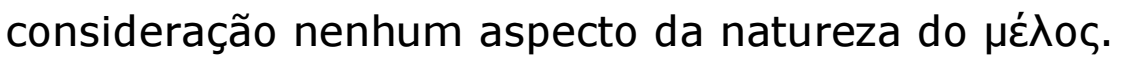

Boécio na sua obra Instituições musicais apresenta uma divisão do cânone, de acordo com os três gêneros musicais. Sua obra influenciará os teóricos medievais e renascentistas que ampliarão as representações do instrumento para sua imago mundi.

\section{O apogeu da ciência pitagórica}

A Divisão do cânone pertence a uma época em que a matemática pitagórica era o modelo de ciência ainda em uso, com aplicações práticas bem determinadas. Umas delas era a acústica dos teatros.

As representações teatrais na Grécia eram feitas ao ar livre, portanto, havia uma preocupação especial com a construção dos anfiteatros, que deveriam abrigar milhares de espectadores. Em geral, eles eram construídos ao longo de uma colina, com uma inclinação de mais ou menos 45 graus com o auditório fazendo um semicírculo em torno do espaço de performance.

Um dos teatros mais famosos é o de Epidauros, construído entre 330-320 a.C., dentro do santuário de Asclepius, o deus da saúde e da medicina. É conhecida a eficiência acústica do seu espaço, quanto à audibilidade e à compreensão das vozes e mesmo para a audição instrumental, como era o caso das representações teatrais

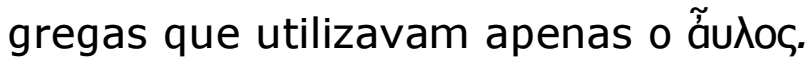

O teatro de Epidauros acomoda 14.000 pessoas e seu desenho faz com que todas elas ouçam e vejam com perfeição. Talvez porque 
suas proporções sejam calculadas a partir de uma unidade de medida relacionada ao corpo humano, o cúbito.

De acordo com o cenógrafo grego Vovolis (2000, p.79), a construção dos teatros gregos era baseada nas proporções matemáticas tal como desenvolvidas pela escola pitagórica. Por exemplo, a relação entre o número de fileiras de assentos em Epidauros, acima (34) e abaixo (21) do corredor central e o conjunto total forma uma proporção áurea 55:34::34:21, que, como vimos é a proporção em que o todo está para a parte maior, assim como esta última está para o todo (Proposição VI.36 de Euclides, Os Elementos). Por fim, o plano horizontal da orquestra está baseado no pentagrama, figura que representava saúde para os pitagóricos.

Vitruvius, do século I d.C., considera que o arquiteto tenha de saber música "para dominar as suas leis harmônicas e matemáticas" (p.33). Ele dedica vários capítulos do Livro $\mathrm{V}$ de seu Tratado de arquitetura à construção dos teatros. O arquiteto propõe a colocação de vasos de bronze nas laterais dos teatros para aperfeiçoar a qualidade de timbre da voz. Os artefatos deveriam estar em proporções matemáticas entre si, levando em conta o tamanho do teatro:

"De acordo com esses princípios, fazem-se vasos de bronze proporcionalmente à grandeza do teatro, devendo ser fabricados de modo que, sendo tocados, produzam entre si sons desde o diatessaron, diapente, e, sucessivamente até ao disdiapason (oitava dupla). Seguidamente, construir-se-ão celas entre os assentos do teatro sendo os vasos aí colocados segundo uma disposição musical, de modo a não tocarem nenhuma das paredes" (Vitrúvio, 2006, p. 185).

Vitrúvio chega ao detalhe de sugerir, para teatros menores uma divisão em doze partes, com cada vaso soando uma nota do gênero 
diatônico grego e, nos teatros maiores, os três gêneros contemplados. Apesar da abordagem claramente pitagórica que perpassa todo o Livro $\mathrm{V}$, é a Aristóxeno que ele recorre quando necessita de um diagrama de fácil aplicação:

"Se alguém, realmente, desejar realizar estas coisas facilmente e com perfeição, veja no fim do livro um diagrama desenhado segundo as regras musicais, que Aristóxeno, com grande brilho e indústria, deixou organizado com as modulações classificadas por gêneros, a partir do qual, aquele que seguir essas regras poderá realizar mais facilmente os acabamentos dos teatros, segundo as características da voz e para deleite dos ouvintes (Vitrúvio, 2006, p. 187)"

Esse modelo em que a harmônica e a natureza - considerando o ser humano como parte dela - estão em uma relação de comensurabilidade, ou de proporção, manter-se-á no mundo grego e romano, permanecerá vivo na Idade Média e alcançará a Renascença, com outras ramificações tanto na arte quanto na ciência. 


\section{CONSIDERAÇÕES FINAIS}

As razões numéricas musicais, tal como elaboradas pela escola pitagórica, tiveram um papel importante no desenvolvimento inicial da ciência grega. Já os princípios aristoxenianos darão impulso à TÉxvn musical, no sentido aristotélico do termo, a capacidade de fabricar ou fazer algo com conhecimento dos princípios envolvidos.

Essa eficiência da arte musical promovida por Aristóxeno

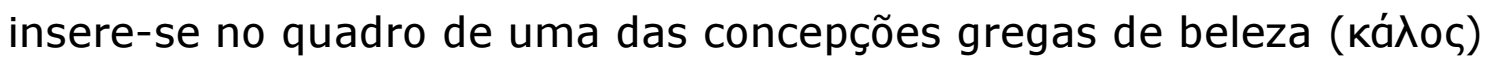
: o critério estético é o da obra bem feita. Aristóxeno não se refere a nenhuma função social para a música, a sua filosofia volta-se toda

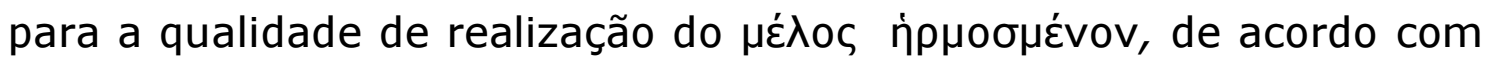
a sua própria natureza.

Essa ligação primeira da música com a natureza está presente tanto na filosofia de Aristóxeno, como herdeiro de Aristóteles, quanto na de Pitágoras. Na obra de arte, há uma reorganização das coisas tal

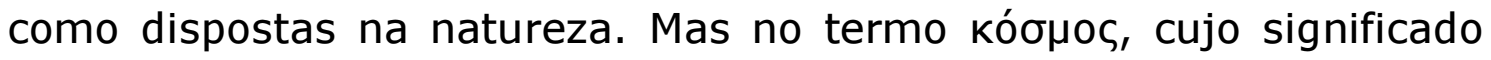
primeiro é ordem, está impressa uma percepção de que esse sentido estético está na natureza e surge da sua contemplação. Já na palavra harmonia, há o sentido de que o prazer estético pode surgir da reciprocidade dos elementos, ou seja, a dissonância é integrada no todo harmônico consonante.

Que a religiosidade mágica pitagórica seja o ponto de partida do processo de racionalização da música ocidental pode parecer paradoxal, mas as escolhas feitas no desenvolvimento dessa arteciência são bastante coerentes com as construções poéticas e científicas de seus empreendedores.

Cabe aqui sublinhar o papel fundamental da analogia como procedimento epistemológico, em especial no pensamento présocrático. Esse aspecto é explorado em profundidade por Abdounour, que enfatiza como "os pitagóricos contribuíram fortemente para o 
desenvolvimento categorial dessa forma de comparação" (Abdounour, 1999, p.116) dando a ele um caráter matemático. Para o autor, o pensamento moderno supervaloriza o pensamento lógico-formal em detrimento do analógico.

No século das Luzes, há uma troca de ênfase do objeto para o sujeito. Um exemplo no âmbito da estética está no texto Standard of taste, do filósofo escocês David Hume (1711-1776): "O belo não é uma qualidade intrínseca aos objetos; ele existe dentro dos espíritos que os contempla, e cada espírito percebe uma beleza diferente" (Apud Chouillet, 1974, p. 65). Esse pensamento digno de um Protágoras, é contraposto na Antiguidade grega a uma teoria da beleza embasada em um substrato ontológico. Mas, de qualquer

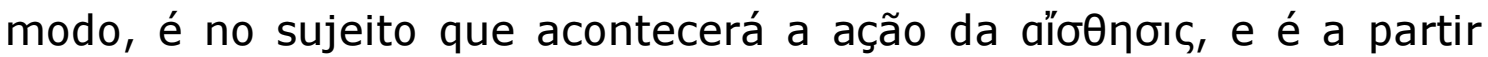
dela que ocorre a distinção entre a consonância e a dissonância.

Os pensamentos subjacentes às duas correntes - aristoxeniana e pitagórica - participarão ativamente da história da música no Ocidente. A geometria musical de Aristóxeno será importante para o desenvolvimento da arte musical, entre outras coisas, por estar em sintonia com uma posição precursora do temperamento igual, por sua vez, responsável pelo desenvolvimento da harmonia e da tonalidade. Mas a supremacia da melodia defendida pelos novos teóricos dos séculos XVI, que conclamavam ideias aristoxenianas, só foi possível por causa do desenvolvimento dos meios advindos do progresso dos questionamentos iniciados pelos pitagóricos.

A pergunta pitagórica - rechaçada por Aristóxeno, que não se interessava pela acústica musical - sobre a causa primeira dos intervalos continuou ressoando e será essa mesma questão que Galileu se fará em 1638. A resposta não utilizará os procedimentos da aritmética pitagórica e, tampouco, da lógica das abordagens qualitativas aristotélicas. Galileu marca o início da física da música ao pensar o fenômeno da altura como frequência de vibrações e 
impactos no tímpano humano, ideia que levaria logo mais ao entendimento do fenômeno da ressonância e da existência dos harmônicos, sons parciais, na composição de um tom musical.

A música seguirá tendo papel preponderante na trajetória dos experimentos acústicos. Mas a realização completa do temperamento só será possível devido a um procedimento matemático, os logaritmos.

Quase quinhentos anos depois da morte de Aristóxeno, em meados do século II d.C., o astrônomo, matemático e geógrafo Cláudio Ptolomeu (100-179 d.C.) escreve a obra Harmônica em três livros nos quais expõe toda a teoria musical da Antiguidade, amplia significativamente os cálculos numéricos pitagóricos e busca incorporar alguns aspectos da filosofia aristoxeniana. Para Ptolomeu, a aritmética e a geometria são "instrumentos de autoridade indiscutível", empregados pela astronomia e pela harmônica "para descobrir a quantidade e a qualidade dos movimentos primários". A ciência dos astros e a musical são "primas, nascidas das irmãs visão e audição, e educadas pela aritmética e a geometria"' (Ptolomeu, 94, 13-20, apud Barker, 2000, p 6)

Aristides Quintiliano (séculos III e IV d.C.) em sua obra sobre música, irá reunir considerações musicais, filosóficas, médicas e gramaticais, com forte influência neoplatônica, tal como o Manual de harmônica, do matemático Nicômaco de Gerasa (II d. C.), que também se insere nessa tradição.

Boécio (480-525/26) encerra os primeiros mil anos de especulação teórica da música, fazendo a ponte para a Alta Idade Média. Na introdução de sua obra Instituições aritméticas, o autor romano define um programa educacional para os estudantes das artes liberais no qual deveriam estar presentes as quatro ciências matemáticas: a astronomia, a aritmética, a geometria e a música. Ele chamou a esse conjunto de quadrivium: trata-se do conjunto de 
disciplinas que deveriam levar o ser humano ao conhecimento das essências imutáveis na natureza. Para o filósofo cristão, as ciências do quadrivium apareciam na seção do estudo dos seres naturais, também chamado de fisiologia ou física. Como estudioso e tradutor dos escritos lógicos de Aristóteles, o autor distinguia a categoria de quantidade em dois gêneros: discreto e contínuo. Na quantidade discreta, a espécie é o número; e a aritmética e a música são as disciplinas matemáticas que lidam com as quantidades discretas, pois a primeira trabalha com o número em si mesmo e a outra, com as relações entre os números (razões e proporções). As outras duas ciências, a geometria e a astronomia, lidam com as quantidades contínuas, as magnitudes geométricas ligadas ao movimento e ao repouso. Suas espécies são a forma imóvel (geometria) ou móvel (astronomia). Uma magnitude pode ser infinitamente dividida, mas a unidade, a origem da quantidade discreta, é indivisível.

Os eruditos concentrados no império de Carlos Magno, na segunda metade do século VIII, seguiram estudando a música como disciplina científica e as anotações nos manuscritos das obras revelam uma verdadeira obsessão com inumeráveis cálculos de razões matemáticas. Em 814, com a dissolução do império carolíngio, essas obras dispersaram-se pelos mosteiros e caíram nas mãos dos religiosos, que deram início à diluição das fronteiras entre a teoria e a prática musical. Os monges passaram a dominar os escritos teóricos mas também a prática musical, de que necessitavam para a rotina diária de entoação dos cantos ritualísticos. Entre os tratados musicais dessa época está a Epístola de harmônica do religioso alemão Regino de Prum (c.842-915), que reúne a matemática musical da época com um tonário, um livro para o estudo sistemático dos modos utilizados nos cantos.

No século XII, em cidades prósperas, surgiram as escolas catedrais, nas quais era incentivado o estudo das artes liberais. A 
escola de Chartres ficará conhecida por cultivar as disciplinas do quadrivium boeciano. Ali eram lidos os fragmentos (17a-53c) do Timeu de Platão, conhecidos através dos comentários do escritor do século IV, Calcídio. Neles estava a passagem em que Platão descreve a criação da alma do mundo com base na escala musical pitagórica. Segundo Alain de Libera, os chartrenses, apesar de não conhecerem nada de Platão além desse fragmento, davam ao autor "um crédito tanto mais intenso quanto mais a sua obra parecia destinada a selar - acordo entre a ciência sagrada, a matemática e os saberes naturais" (2004, p.314). Na mesma época, em Paris, Hugo de São Vítor expunha a classificação em quatro partes de sua filosofia: teórica, prática, mecânica e lógica. A música mantinha-se na parte teórica, como uma das quatro matemáticas, aquelas que deveriam tratar das formas invisíveis (no caso da música, inaudíveis) das coisas visíveis (audíveis).

Com o desenvolvimento do humanismo na Itália, no início do século XV, assuntos e práticas relacionados ao estudo das humanidades, como a retórica e a poesia, foram penetrando nas reflexões e nos escritos sobre a música, afastando-a de sua estreita vinculação às matemáticas. No século XVI, essas ideias adentraram a obra dos compositores madrigalistas, em geral flamencos, que vinham para a Itália em busca de trabalho. Um deles foi Adrian Willaert (1490-1562), diretor musical da Igreja de São Marcos em Veneza de 1527 até 1562 e grande responsável pelo estabelecimento do magnífico idioma coral da escola veneziana. Willaert reunia as qualidades do músico teórico com uma profunda experiência da arte musical. A partir dele, os compositores começam a influenciar mais diretamente a teoria musical. A hierarquia de Boécio desmoronava e suas três "músicas" se fundiam em uma só.

Nesse período, que tem como pano de fundo a preparação de um novo ciclo do pensamento ocidental, a obra Elementos de 
harmônica é traduzida para o italiano, levando a tensão criada entre as correntes da matemática e da sensação ao seu ápice.

No século XVII, a ideia de harmonia universal continua presente: analogia viva entre os elementos da natureza que deviam ressoar entre si por simpatias. Essa visão está representada na imagem do livro de Robert Fludd, Utriusque cosmi historia, de 1617: um imenso monocórdio, cuja cravelha é ajustada por uma "mão cósmica" envolta em uma nuvem. As proporções matemáticas afinam as consonâncias musicais, os planetas e os elementos.

A ideia de que todas as partes do universo estão conectadas harmônica e simpateticamente, que todos os seres constituem uma imensa cadeia contínua, é um fenômeno facilmente demonstrável nas propriedades de ressonância de instrumentos musicais, especialmente daqueles de cordas; por exemplo, com dois alaúdes: tangendo as cordas de um, o outro vibra. Segundo Gouk, "embora o experimento tenha sua origem no contexto da magia natural, no século XVII, ele será incorporado pela nova filosofia experimental como uma maneira de visualizar outras espécies de vibrações ocultas, mas naturais" (2002, p.231).

O modelo de harmonia universal segue presente nas investigações do astrônomo alemão Johannes Kepler (1571-1630), ao mesmo tempo em que sofrerá rupturas mais profundas com a filosofia de René Descartes (1596-1650). O pensamento cartesiano ecoará, no século XVIII, na teoria musical de Jean-Philippe Rameau (1683-1764), que introduzirá a ideia de forças naturais nas relações sistêmicas da linguagem musical, enfatizando não mais os intervalos entre dois tons, mas formações de acordes, conjunto de três tons ou mais. Contemporâneo de Rameau, Johann Sebastian Bach (16851750) irá sintetizar em sua arte toda a tradição ocidental até então, reunindo organologia, técnica, matemática e poesia de modo que 
nenhum grego pudera sequer imaginar. Em seu tempo, a música alcançará sua completa autonomia.

Ao lado das transformações que começam a ocorrer na história da teoria musical, a música segue sendo estudada como disciplina científica dentro do currículo da educação superior na Europa até o século XVIII. Isso explica a sua presença, às vezes determinante, na obra de cientistas e filósofos como Kepler, Galileu, Mersenne, Descartes, Huygens, Leibniz, Bacon, Newton, entre outros, que escreveram com desenvoltura sobre a música e a utilizaram como base de suas teorias e experimentos. Nesse momento, novas concepções e experimentos relacionados ao som musical darão impulso à física em geral e à acústica em particular.

A partir do século XVIII, o foco da música desloca-se completamente do âmbito científico para o estético, mas a música segue guiando os estudos em acústica. Em 1701, Joseph Sauveur (1653-1716) publica sua obra Princípios de acústica e de música, na qual expõe a noção de frequência musical. Por volta de 1739, 0 matemático Leonard Euler (1707-1783) apresenta sua teoria da consonância baseada em leis matemáticas no livro Tentamen novae theoriae musicae, ex certissimis harmoniae principiis dilucidae expositae.

O médico, físico e matemático Hermann von Helmholtz (18211894), no século XIX, funda o estudo da fisiologia do ouvido e leva adiante inúmeras pesquisas relacionadas à música, explicando o papel dos harmônicos no timbre e a natureza dos pulsos nas consonâncias e dissonâncias. O som passa a ser considerado não como vibração, mas como onda, e a matemática volta à cena musical, quando Fourier faz a representação matemática de curvas periódicas através da superposição de senóides, mostrando que elas correspondiam a uma série de 1,2, 3, 4 vezes a frequência da curva 
original. Essa Série de Fourier correspondia à sequência ordenada dos harmônicos, do grave ao agudo.

Com o desenvolvimento da fisiologia foi possível demonstrar que o ouvido humano analisa sons complexos através de componentes mais simples, as senóides. Seria possível fazer uma analogia dessa descoberta com a perplexidade que deve ter atingido o coração dos pitagóricos ao se depararem com as razões dos quatro primeiros números inteiros como explicação para as consonâncias? 0 fato é que algumas questões ainda não foram totalmente compreendidas, entre elas, exatamente a origem da consonância e da dissonância, problema central da harmônica de Pitágoras (Taylor \& Campbell, 2009) ${ }^{40}$.

O desenvolvimento das técnicas de gravação e o surgimento das músicas concreta e eletrônica, no início do século $\mathrm{XX}$, agregaram novos ingredientes à música e à ciência musical. Eimert encerra seu prefácio ao livro Que es la música eletrônica? dizendo: "A relação com o som nunca foi tão direta como hoje. O som segue sendo, para o teórico, a fonte principal" (Eimert, 1973, p.21).

Aristóxeno, o mousikós, teria dito de outro modo. O que interessa à música é o som musical. A altura, ou a frequência do som, só interessa a partir do momento em que se transforma em tom e desabrocha no ritmo. Com a noção de tom podemos explicar a transposição de melodias, algo tão inerente à natureza humana. Pois,

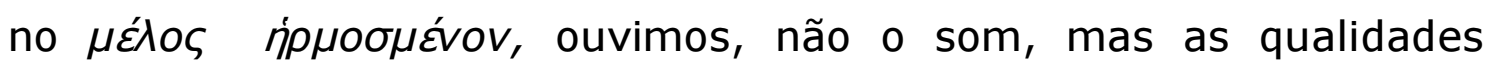
dinâmicas inerentes ao tom, movendo-se no espaço musical.

\footnotetext{
40 "There remains problems in understanding the mechanism of hearing, the origins of consonance and dissonance, the precise way in which ear and brain respond to transients, and the phenomena of aural illusions". Taylor, Charles and Campbell, Murray. In: Sound. www.oxfordmusiconline.com
} 


\section{BIBLIOGRAFIA}

ABDOUNOUR, Oscar João. Matemática e música. São Paulo, Escrituras, 1999.

ALBERTINI, Tamara."Marsilio Ficino - Dar forma estética ao mundo por meio do pensamento". In: BLUM, P. R. (org.), Filósofos da Renascença. Editora Unisinos, São Leopoldo: RS, 2003, p.106-118.

ANAXÍMENES. Fragmentos. Trad. de Wilson Régis. Coleção "Os Pensadores". São Paulo, Abril Cultural, 1973, p. 57-58.

ANÔNIMO. Inni Homerici. Milão, Mondadori, 2000.

ARISTÓTELES. Categorias. Trad. de José Veríssimo Teixeira da Mata. Goiânia, Editora Alternativa, 2005.

- Física I-II. Trad. de Lucas Angioni. Clássicos da Filosofia: Cadernos de Tradução n.1., Campinas, Unicamp, 2002.

. Metafísica. Trad. de Vinzenzo Cocco. Coleção "Os Pensadores". São Paulo, Abril Cultural, 1979. '

- Physics. Books I-IV. Loeb Classical Library. Harvard University Press, 1996.

- Problemas musicais. Trad. de Maria Luiza Roque. Brasília, Thesaurus, 2001.

ARISTOXENI. Elementa harmonica. Ed. Rosetta da Rios. Roma, Typis Publicae Officinae Polygraphicae, 1954.

ARISTOXENUS. The harmonics. Trad. de Henry Macran. Hildesheim, Georg Olms Verlag, 1974.

ARQUITAS. Fragmentos. Trad. de Ísis L. Borges. Coleção "Os Pensadores". São Paulo, Abril Cultural, 1973, p. 260-261.

BAILLY, A. Dictionnaire Grec-Français. Paris, Hachette, 26ª ed., 1963. 
BARBERA, Andre. "Archytas of Tarentum". Disponível em: Grove Music Online:http://www.oxfordmusiconline.com/subscriber/article/grove/m usic/01183. Acesso em: 6 fev. 2009.

. The consonant eleventh and the expansion of the musical tetráktys: a study of ancient pythagoreanism. Journal do Music Theory, vol. 28, no. 2, pp. 191-223. Yale: Duke University Press, 1984.

. The euclidean Division of the Canon. University of Nebraska, 1991.

BARBOUR, Murray. Tuning and temperament. Nova York, Dover Publications, 2004.

BARCO, Luiz. "O piano e a tábua de logaritmos". In: Superinteressante, $n^{\circ}$. 7, Editora Abril, São Paulo, 1988, p.44.

BARKER, Andrew. Greek musical writings. Vol. II, Harmonic and acoustic theory. Cambridge, Cambridge University Press, 1989.

. "Music and perception: a study in Aristoxenus". In: Journal of Hellenic Studies. Cambridge, 1978, p.9-16.

. Scientific method in Ptolomy's harmonics. Nova York, Cambridge University Press, 2000.

. The science of harmonics in classical Greece. Nova York, Cambridge University Press, 2007.

BÉLIS, Annie. Aristoxène de Tarente et Aristote: Le traité d'harmonique. Paris, Klincksieck, 1986.

. "Harmonique". In: Le savoir grec. Paris, Flammarion, 1996, p.352367.

. "L'harmonique comme science dans l'antiquité grecque" In: Quadrivium, musiques et science, 33. Paris, Ed. IPMC, 1992, p.201208. 
BOEHNER, Philoteus \& GILSON, Etienne. História da filosofia cristã. Petrópolis, Vozes, 1985.

BOLLACK, Jean. Empedocle. Paris, Les Editions de Minuit, Gallimard, 1969. BORZACCHINI, Luigi. "Incommensurability, music and continuum: a cognitive approach". In: Archives history exact science, 61, 2007, p.273-302.

BOWER, Calvin. "Boethius". Disponível em: Grove Music Online ed. L. Macy: http://www.oxfordmusiconline.com:80/subscriber/article/grove /music/03386. Acesso em: 18 fev. 2009.

. "The transmission of ancient music theory in Middle Ages". In: CHRISTENSEN, Thomas (ed.). Western music theory. Ed. Cambridge, Cambridge University Press, 2002, p.136-167.

BOYER, Carl. História da matemática. São Paulo, Editora Edgard Blücher, 1999.

BOWLES, Edmund. "Instruments and technology". Disponível em: Grove Music Online, MACY, L. (ed.):http://www.grovemusic.com. Acesso em: 8 maio 2008.

CANDÉ, Roland de. História universal da música. Vol. 1. Martins Fontes, São Paulo, 2001.

CHARRAK, André. Musique et philosophie à l'âge classique. Paris, Presses Universitaires de France, 1998.

CHRISTENSEN, Thomas ."Genres of music theory, 1650.1750". In: Towards tonality. Ghent, Leuven University Press, 2007, p.9-39. . (ed.) Western music theory. Cambridge, Cambridge University Press, 2002.

CHOUILLET, Jacques. L'esthétique des Lumières. Paris, Presses Universitaires de France, 1974. 
COHEN David. "The imperfect seeks perfection: harmonic progression, direct motion and Aristotelian physics". In: Music theory spectrum, 23/2. Columbia University, 2001, p.139-168.

COHEN, H. Floris. "Beats and the origins of early modern science". In: COELHO, Victor (ed.). Music and science in the age of Galileo. Dordrecht, Kluwer Academic Publishers, 1992, p.17-34.

. Quantifying music. Dordrecht, Reidel Publishing Company, 1984.

DELATTE, Armand. Études sur la littérature pythagoricienne. Slatkine Reprints, Genebra, 1974.

DEL GRANDE, Carlo. "Cenni sulla musica greca". In: Enciclopedia Clasica, Vol. V, Sezione II. Torino, Societá Editrice Internazionale, 1960.

DISTROVSKY, Sigalia et al. "Physics of music." Disponível em: Oxford MusicOnline: http://www.oxfordmusiconline.com/subscriber/article/gr ove/music/43400. Acesso em: 6 fev. 2009.

DRAKE, Stillman. "Music and philosophy in early modern science". In: COELHO, Victor (ed.). Music and science in the age of Galileo. Dordrecht, Kluwer Academic Publishers, 1992, p.3-16.

EIMERT, Herbert et al. Que és la música electrónica? Ediciones Nueva Visión, Buenos Aires, 1973.

FERGUSON, Donald. A short history of music. Nova York, F.S.Crofts, 1943.

FILOLAU. Fragmentos. Trad. de Ísis L. Borges. Coleção "Os Pensadores". São Paulo, Abril Cultural, 1973, p. 256-258.

FINLEY, Moses. Grécia primitiva: idade do bronze e idade arcaica. Martins Fontes, São Paulo, 1990.

FRANKLIN, John Curtis. "Musical sincretism in the Greek orientalizing period". In: HICKMANN, E. \& EICHMANN, R. (eds.), Archäologie früher Klangerzeugung und Tonordnungen. Série "Estudos de 
Arqueomusicologia". Orient-Archäologie Deutsches Archäologisches Institut Berlin, Orient-Abteilung, 2002, p.441-451.

GALILEI, Galileu. Duas novas ciências. Trad. de Letizio Mariconda e Pablo Rubén Mariconda. São Paulo, Nova Stella, 1988.

GALILEI, Vincenzo. Dialogue on ancient and modern music. Yale, Yale University Press, 2003.

GIBSON, Sophie. Aristoxenus of Tarentum and the birth of musicology. Nova York, Routledge, 2005.

GOUK, Penelope. "The role of harmonics in the scientific revolution". In: CHRISTENSEN, Thomas (ed.). Western music theory. Cambridge, Cambridge University Press, 2002, p.223-245. . "Science and music or the science of music: some little-known examples of 'music theory' between 1650 and 1750". In: Towards Tonality. Ghent, Leuven University Press, 2007, p.41-68.

GOZZA, Paolo. "Introduction". In: Number to sound: the musical way to the scientific revolution. Dordrecht, Kluwer Academic Publishers, 2000, p.1-63.

GHYKA, Matila. The geometry of life. Nova York, Dover Publications, 1977. GIBSON, Sophie. Aristoxenus of Tarentum and the birth of musicology. Nova York, Routledge, 2005.

HALLYN, Fernand. La structure poétique du monde: Copernic, Kepler. Paris, Seuil, 1987.

HANSLICK, Eduard. Do belo musical. Campinas, Editora da Unicamp, 1992.

HEATH, Sir Thomas. A history of greek mathematics. Oxford, Clarendon Press, 1981.

HERÁCLITO. Fragmentos. Trad. de José Cavalcante de Souza. Coleção "Os Pensadores". São Paulo, Abril Cultural, 1973, p. 85-97. 
HUFFMANN, Carl. "Archytas". In: ZALTA, Edward N. (ed.), The Stanford Encyclopedia of Philosophy (Fall 2008 Edition). Disponível em: http://plato.stanford.ed.u/archives/fall2008/entries/archytas/

. "Philolaus". In: ZALTA, Edward N. (ed.), The Stanford Encyclopedia of Philosophy (Summer 2005 Edition). Disponível em: http://plato.stanford.ed.u/archives/sum2005/entries/philolaus/ ."Pythagoreanism". In: ZALTA, Edward N. (ed.), The Stanford Encyclopedia of Philosophy (Fall 2008 Edition). Disponível em: http://plato.stanford.edu/archives/fall2008/entries/pythagoreanism HUNT, Frederick Vinton. Origins in acoustics. Yale, Yale University Press, 1978.

JÁMBLICO. Vida pitagórica. Madri, Editorial Gredos, 2003.

KEPLER, Jean. L'harmonie du monde. Paris, Librairie Blanchard, s.d.

KUHN, Thomas. "Comment on the relations of Science and Art". In: The essential tension. Chicago, The University of Chicago Press, 1977, p.340-351.

LAWLOR, Robert. Sacred geometry. Londres, Thames and Hudons, 1990.

LIBERA, Alain de. A filosofia medieval. São Paulo, Edições Loyola, 2004.

LIPPMAN, Edward. A history of western musical aesthetics. Nebraska, University of Nebraska Press, 1992.

LENOBLE, Robert. História da idéia de natureza. Edições 70, Lisboa, 2002.

LIVIO, Mario. Razão áurea. A história de Fi, um número surpreendente. São Paulo, Editora Record, 2006.

MAAS, Marha \& SNYDER, Jane MacIntosh. Stringed instruments in ancient Greece. New Haven e Londres, Yale University Press, 1989.

MATHIESEN, Thomas. Apollo's lyre. Nebraska, University of Nebraska Press, 1999. 
MERLEAU-PONTY, Maurice. A natureza. Martins Fontes, São Paulo, 2006.

MERSENNE, Marin. Traité de I'harmonie universelle. Paris, Fayard, 2003.

. "Traité des instruments: Livre Premier, Livre Second". In: Harmonie universelle. Paris, Éditions du Centre National de La Recherche Scientifique, 1986.

NICÔMACO de Gerasa. The manual of harmonics. Trad. de Flora Levin. Grand Rapids, Phanes Press, 1994.

OSBORNE, Harold. Estética e teoria da arte. São Paulo, Edusp, 1974.

PALISCA, Claude. Music and ideas in the sixteenth and seventeenth centuries. Illinois: University of Illinois Press, 2006.

. "Galilei, Vincenzo". Disponível em: Grove Music Online, MACY, L.

(ed.) http://www.grovemusic.com. Acesso em: 8 maio 2008.

. "Three scientific essays by Vincenzo Galilei". In: The Florentine

Camerata. Londres, Yale University Press, 1989, p.152-207.

PIERCE, John. Los sonidos de la musica. Barcelona, Prensa Científica, 1985.

PLATÃO. Epinomis. Introd., trad. e notas de E. des Places. Paris, Belles Lettres, 1956, p.131-162.

- Epistle VII (Sétima Carta). Loeb Classical Library, Livro IX. Harvard University Press, 1989, p.463-565.

. La Repubblica (República). Milão, Mondadori, 1990.

. Phaedrus (Fedro). In www.perseus.tufts.edu

- Philebus (Filebo). Loeb Classical Library, Livro VIII. Harvard University Press, 1995, p.202-399.

- Theaethetus (Teeteto). Loeb Classical Library, Livro VII. Harvard University Press, 1996, p.6-257. 
- Timaeus (Timeu). Loeb Classical Library, Livro IX. Harvard University Press, 1989, p.16-253.

PRYNNE, Michael W. "The lute". In: BAINES, A. (ed.), Musical instruments through the ages. Middlesex: U.K., Penguin Books, 1963, p.157-165.

RASCH, Rudolf. "Tuning and temperament" In: CHRISTENSEN, T. (ed.), Western music theory. Cambridge, Cambridge University Press, 2002, p.193-222.

RIOS, Rosetta da. Aristoxeni Elementa Harmonica, Roma, Typis Publicae Officinae Polygraphicae, 1954.

RIZEK, Ricardo. "Teoria da harmonia em Platão". In: Letras Clássicas. Ano 2, no. 2. São Paulo, Humanitas, 1998, p.251-299.

- A teoria da harmonia em Platão. Dissertação de mestrado apresentada ao departamento de Música da Escola de Comunicações e Artes, USP. São Paulo, 2003.

ROSSI, Paolo. Philosophy, tecnology and the arts in the early modern era. Nova York, Harper Torchbooks, 1970.

ROCHA, Roosevelt Araújo da. "Música e filosofia em Platão e Aristóteles". In: Revista Discurso, nº. 37. São Paulo, 2007, p.29-53.

STEWART, Ian. Nature's numbers. Londres, Orion Books, 1995.

SPITZER, Leo. L'armonia del mondo. Bologna, Il Mulino, 2009.

SZABÓ, Arpád. L'aube des mathematiques grecques. Paris, Librairie Philosophique J. Vrin, 2000.

- Les débuts des mathématiques grecques. Paris, Librairie Philosophique J. Vrin, 1977.

TANNERY, Paul. "Le rôle des mathematiques grecques dans la mathematique pure". In: Memoires scientifiques. Paris, GauthierVillars, 1902, p.71-89. 
TAYLOR, Charles \& CAMPBELL, Murray. "Sound." Disponível em: Grove MusicOnline:www.oxfordmusiconline.com/subscriber/article/grove/mu sic/26289 Acesso em: 6 fev. 2009.

VAN WYMEERSCH, Brigitte. Descartes et l'evolution de l'esthétique musicale. Sprimont: Bélgica, Pierre Mardaga Editeur, 1999.

VERNANT, Jean-Paul. "Geometria e astronomia esférica na primeira cosmologia grega". In: Mito e pensamento entre os gregos. São Paulo, Edusp, 1973, p.156-167.

VITRÚVIO - Tratado de arquitetura. Lisboa, IST Press, 2006.

VOVOLIS, Thanos. "The voice and the mask in ancient Greece". In: Soundscape. Londres, Wallflower Press, 2007, p.73-82.

WALKER, D. P. Studies in musical science in the late Renaissance. Londres, The Warburg Institute, 1978.

WEBER, Max. Os fundamentos racionais e sociológicos da música. São Paulo, Edusp, 1995.

WERSINGER, Anne Gabrièle. Platon et la dysharmonie. Paris, Librairie Philosophique J. Vrin, 2001.

WEST, M. L. "The singing of Homer and the modes of early greek music." In: The Journal of Hellenic Studies, 101. Cambridge, 1981, p.113129.

ZAMACOIS, Joaquín. Tratado de armonia. Libro III. Barcelona, Editorial Labor, 1979.

ZARLINO, Gioseffo. The art of counterpoint. The Norton Library, Nova York, 1968.

ZINGANO, Marco. Razão e sensação em Aristóteles. Porto Alegre, L\&PM Editores, 1998. 
